УДК 902/903

https://doi.org/10.24852/2587-6112.2021.2.108.169

\title{
ОДОЕВСКОЕ ГОРОДИЩЕ. К ВОПРОСУ О КУЛЬТУРНОЙ СПЕЦИФИКЕ ПОВЕТЛУЖЬЯ В РАННЕМ ЖЕЛЕЗНОМ ВЕКЕ
}

\author{
(C)2021 г. А.В. Новиков
}

Статья вводит в научный оборот материалы, полученные в результате раскопок Одоевского городища в 1925-1926 гг. Б.С. Жуковым и О.Н. Бадером. В работе поставлены вопросы культурной специфики региона Поветлужья в раннем железном веке, рассматриваются и определяются основные векторы межкультурного взаимодействия. Наибольшее внимание уделено керамическим комплексам Одоевского городища. Впервые выделена керамика «одоевского типа» с рамчатым декором, предананьинского времени, вероятно, появившаяся на поселении в конце II - на рубеже II-I тыс. до н.э., и гибридная керамика с признаками рамчатой «одоевского типа» и лебяжской. Проанализированы находки вятско-ветлужской культуры АКИО. В коллекции преобладает ананьинская керамика с прямой или слегка отогнутой шейкой и слабовыпуклыми плечиками. При орнаментации чаще всего использован гребенчатый штамп. Изготовлена посуда преимущественно из незапесоченных и слабозапесоченных глин с примесью в формовочной массе раковины, раковины и шамота или шамота с органическими остатками. В статье определены общие признаки, которые позволяют отметить близость керамики и костяных изделий из поселений бассейна рек Вятки и Ветлуги. Выделены специфичные черты, указывающие на некоторое своеобразие ананьинской керамики из Одоевского городища и ее отличие от вятской, которые обосновываются как географическим расположением памятников, так и культурной спецификой, основанной на степени взаимодействия с другими культурными группами внутри ананьинского мира. Установлены особенности сетчатой посуды, появившейся на памятнике в позднеананьинский период. Начало ананьинского заселения городища приходится на VII вв. до н.э., завершающий этап - на III/II вв. до н.э.

Ключевые слова: археология, Поветлужье, Одоевское городище, финал эпохи бронзы, ранний железный век, керамика с рамчатым декором «одоевского типа», вятско-ветлужская культура АКИО, сетчатая керамика.

\section{ODOEVSKOYE HILLFORT. THE ISSUE OF THE CULTURAL SPECIFIC OF THE VETLUGA REGION IN THE EARLY IRON AGE}

\begin{abstract}
A.V. Novikov
The paper introduces into scientific discourse the materials obtained as a result of excavations at Odoevskoe hillfort in 1925-1926 by B.S. Zhukov and O.N. Bader. The paper addresses the issues of the cultural attributes of the Vetluga region in the Early Iron Age, examines and defines the main vectors of intercultural interaction. The greatest attention is paid to the ceramic complexes of Odoevskoe hillfort. For the first time, the ceramics of the "Odoevskoe type" with framed decoration from the Pre-Ananyino period, which probably appeared at the settlement in late $2^{\text {nd }}$ - the turn of the 2 nd millennium $B C$, and hybrid ceramics with signs of the framed "Odoevskoe type" and Lebyazhskaya type were identified. The finds of the Vyatka-Vetluga culture of the Ananyino Cultural and Historical Region are analyzed. The collection is dominated by Ananyino ceramics with a straight or slightly bent neck and slightly convex shoulders. A combed stamp is most frequently used for ornamentation. The ware was made mainly of non-sandy and slightly sandy clays with an admixture of shells, shells and chamotte, or chamotte and organic residues in the molding mass. The author outlines the common features allowing to note the close similarity of the ceramics and bone products from the settlements of the Vyatka and Vetluga rivers basins. The specific features are outlined, which indicate a certain originality of the Ananyino ceramics from Odoevskoe hillfort and its difference from the Vyatka items, which are justified both by the geographical location of the monuments and the cultural specificity based on the degree of interaction with other cultural groups within the Ananyino world. The attributes of the mesh ware having appeared at the site in the Late Ananyino period have been established. The beginning of the Ananyino settling of the hillfort took place in 7th century $\mathrm{BC}$, and the final stage - in the $3^{\text {rd }} 2^{\text {nd }}$ centuries $\mathrm{BC}$.

Keywords: archaeology, Vetluga region, Odoyevskoe hillfort, Final Bronze Age, Early Iron Age, ceramics with frame decoration of the "Odoyevskoe type", Vyatka-Vetluga culture of the Ananyino Cultural and Historical Region, mesh ceramics.
\end{abstract}


Одоевское городище находится на коренной террасе правого берега р. Ветлуги на длинном узком мысу, образованном высоким обрывистым берегом р. Ветлуги с северо-востока и оврагом с юго-запада, по дну которого течет ручей Городищенский. В длину городище достигает 55 м, ширина мыса у вала равняется 25 м, высота над уровнем реки 18-20 м. Склоны и овраг заросли густым смешанным лесом, площадка городища поросла частым мелколесьем. С напольной южной стороны его ограничивает вал, имеющий высоту от уровня рва до 5 м, длину по основанию 17 м и ширину в основании 12 м. На вершине вала имеется ровная площадка, почти круглая в плане, диаметром 7-8 м. За валом прослеживается неглубокий заплывший ров шириной около 3 м и глубиной относительно внешнего поля до 3 м. Площадка городища идет уклоном от вала к оконечности мыса и в сторону оврага. Мощность культурного слоя памятника составляет 60-100 см, местами достигает 250 см (Жуков, Бадер, 1925-1926). Б.С. Жуковым и О.Н Бадером выделено несколько культурных слоев: первый слой имеет темно-серый, иногда черный окрас, а его мощность варьирует от 25 до $175 \mathrm{~cm}$, он отделен от второго слоя прослойкой глины; второй слой - серого цвета, его мощность варьирует от 10 до $90 \mathrm{~cm}$; остаточная толщина третьего слоя составляет всего 3-6 см, он также имеет серый окрас (Бадер, 1951a, с. 118-119).

Городище мысового типа открыто в 1883 г. Ф.Д. Нефедовым, в 1903 г. небольшие раскопки здесь произвел Н.М. Бекаревич. Важная заслуга в полевом изучении памятника принадлежит Б.С. Жукову, который в 1925 1926 гг. совместно с О.Н. Бадером заложил раскоп у юго-западного края городища и ряд шурфов по всей его площади (рис. 1). В 1981 г. городище обследовал К.И. Комаров (Комаров, 1999, с. 288), в 1999 г. А.В. Новиков.

В настоящей статье анализируются материалы, полученные при раскопках памятника в 1925-1926 гг. 16-26 июля 1925 г. работы на городище выполнялись под руководством Б.С. Жукова (ассистент О.Н. Бадер) на площади более 40 кв. м. 25-30 июня 1926 г. раскопки на площади 29 кв. м проведены по поручению Б.С. Жукова под руководством О.Н. Бадера (Жуков, Бадер, 1925-1926). Часть материалов исследований ранее публиковалась (Бадер, 1951a; 1951б; Воеводский, 1951, Формозов, 1951). Следует обозначить, что верхние хронологические пределы рассматриваемых в настоящей работе вещевых комплексов ограничиваются кругом ананьинских древностей, более поздняя керамика (штрихованная и заглаженная с минеральными примесями), обнаруженная в первом слое памятника (по О.Н. Бадеру), не анализируется. О.Н. Бадер датировал комплексы такой керамики первыми веками н. э. (Бадер, 1951б, с. 31) и считал, что керамика верхнего слоя ближе керамике позднедьяковских городищ из более западных районов Поволжья, а также верхних слоев городищ на р. Унже и генетически она не связана с керамикой второго слоя, что, на его взгляд, свидетельствует о смене «культурных форм» на Одоевском городище и в Поветлужье в целом (Бадер, 1951a, с. 153-155). Эти вопросы заслуживают отдельного внимания.

В IX-VIII вв. до н. э. формируется АКИО (Кузьминых, Чижевский, 2017, с. 24). Современная периодизация АКИО выглядит следующим образом: раннеананьинский период IX - первая половина VII вв. до н. э. (делится на два этапа: IX - середина VIII вв. до н. э. и середина VIII - первая половина VII вв. до н. э.), средний этап - вторая половина VII - V вв. до н. э., и поздний этап, который соотносится с концом V - III/II вв. до н. э. (Кузьминых, Чижевский, 2014; Чижевский, 2017). В рамках АКИО выделено четыре стержневые культуры, которые, однако, не имеют четко очерченных границ (Кузьминых, Чижевский, 2009 ; 2017, с. 25; Чижевский, Хисяметдинова, 2020). Постмаклашеевская культура хронологически совпадает со всем периодом развития ананьинских древностей - IX-III вв. до н. э. (Чижевский и др., 2019, с. 135). Акозинская (Кузьминых, 1983; Чижевский и др., 2019) или акозинско-ахмыловская культура (Кузьминых, Чижевский, 2017), индикаторами которой являются кельты акозинско-меларского типа и текстильная керамика (Кузьминых, 1977, с. 138-139), датируется IX-VI вв. до н. э. (Чижевский 2020, с. 167), её ареал включает Чувашско-Марийское Поволжье и Нижнюю Оку (Кузьминых, Чижевский, 2009, с. 34). Основной территорией культуры классической шнуровой керамики являются районы Нижнего и Среднего Прикамья и бассейна р. Белой. В бассейне рек Вятки и Ветлуги распространена культура гребенчато-шнуровой керамики (Кузьминых, Чижевский, 2009, c. 35). АКГШК получает название и вятсковетлужской (Чижевский, Хисяметдинова, 2020). Отметим, что гребенчато-шнуровую керамику вятско-ветлужской называл еще В.Н. Марков (Марков, 2007). Обоснование названия вятско-ветлужской культуры сделали 


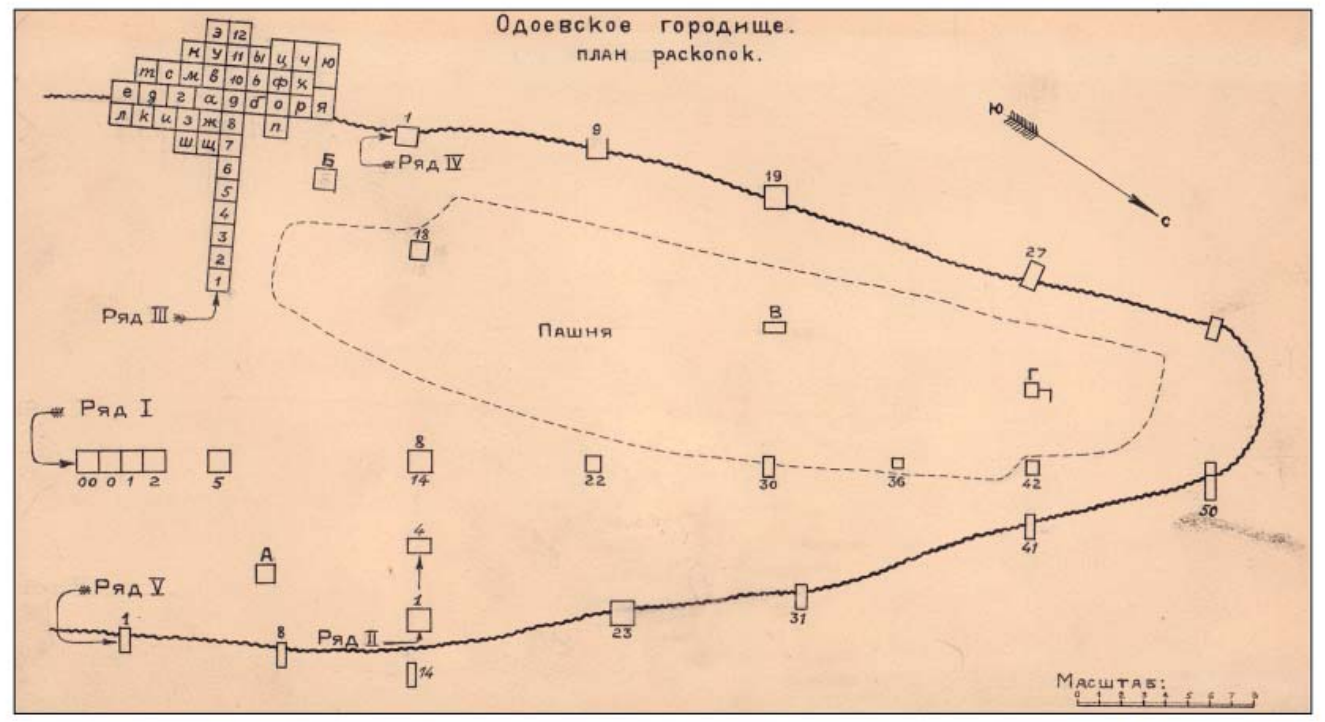

Рис. 1. План Одоевского городища с расположением раскопов и шурфов 1925-1926 гг. (по: Б.С. Жуков, О.Н. Бадер, 1926). Из собрания ГБУК Нижегородской области «Нижегородский государственный историко-архитектурный музей-заповедник»

Fig. 1. Plan of the Odoevsky hillfort with the location of excavations and shafts of 1925-1926

(after B.S. Zhukov, O.N. Bader, 1926). From the collection of the State Budgetary Institution of Culture of Nizhny Novgorod Oblast "Nizhny Novgorod State Historical and Architectural Museum-Reserve"

А.А. Чижевский и Э.И. Оруджов (Чижевский, 2021). Исходя из этой позиции и в рамках этих культурных традиций начнем рассматривать материалы из Одоевского городища.

Памятники бассейна рек Вятки и Ветлуги занимают обособленную территорию и культурную нишу в рамках АКИО, на что обращают внимание большинство исследователей ананьинских древностей (Бадер, 1951a; 1951б; Збруева, 1952; Смирнов, 1961; Халиков, 1977; Марков, 2007; Чижевский, 2008; Митряков, Черных, 2014; Кузьминых, Чижевский, 2009; 2017; и др.). Наиболее изученными к настоящему времени являются памятники РЖВ бассейна р. Вятки, в отличие от поселений Поветлужья, на которых необходимо в первую очередь проведение новых полевых работ, а также переосмысление уже полученных материалов, вследствие чего в настоящее время отсутствует возможность полноценного сравнения между ними.

На особые черты керамических комплексов из поселений бассейна р. Ветлуги и их отличие от керамики из синхронных памятников Прикамья обратил внимание еще О.Н. Бадер, высказавший мнение об особом варианте ананьинской культуры в Поветлужье (Бадер 1951a, с. 151-152; 1951б, с. 22), с этим мнением согласилась и Н.Н. Гурина (1961, с. 201). А.В. Збруева также выделяла ветлужскую группу ананьинских памятников (пятая локальная группа), посуда которой, по ее мнению, по орнаментации очень близка вятской (Збруева, 1952, с. 73). Горюнова Е.И. отмечала определенное своеобразие памятников региона Поветлужья, представляющих собой локальный вариант ананьинской культуры (Горюнова, 1961, с. 22-23). А.П. Смирнов видел Ветлугу далекой периферией ананьинской культуры и относил к её ареалу Одоевское, Богородское, Русенихинское и Чортово (Федоровское) городища, отмечая, что их керамика представляет собой особый вариант ананьинской, отличный от классической (Смирнов, 1952, с. 62; 1961, с. 90). В.Е. Стоянов отмечал близость керамики из 2 и 3 слоёв Богородского и Русенихинского городищ с вятскими памятниками и поселениями бассейна р. Камы, но также указывал, что она не полностью идентична и имеет специфичные черты (Стоянов, 1959).

А.Х. Халиков говорил о близости раннеананьинской керамики из вятских и ветлужских памятников, усматривая при этом и средневолжский след при формировании ананьинской культуры в Поветлужье (Халиков, 1962, c. 13), и обособил территорию Ветлужского бассейна, выделив ветлужский вариант раннеананьинских памятников, датировав его VIII-VI вв. до н. э. (Халиков, 1977, с. 15-16). К этому варианту отнесены Одоевское городище (третий слой), Пановское селище (верхний слой), Богородское (второй слой) и Русенихинское (второй слой) городища (Халиков, 1977, с. 10, 15). А.Х. Халиков выделил особенности керамики ветлужского варианта, 
которые, на его взгляд, выражались в преобладании цилиндрошейных сосудов с плавным переходом к тулову, содержанием в примеси раковины, украшением сосудов шнуровыми оттисками в сочетании с зубчато-гребенчатыми, наличием орнамента и по краю венчика (Халиков, 1977, с. 241-242).

Значимый вклад в теоретическое осмысление материалов из памятников Поветлужья внёс В.Н. Марков. Исследователь говорил о близких взаимосвязанных процессах, проистекавших в Поветлужье и Вятском бассейне (Марков, 1988; 2007), указывая при этом, что ветлужское население ананьинского времени, судя по значительному сходству в керамике, было родственным вятскому и имело с ним общие истоки (Марков, 1988, с. 104). Исследователь обобщил сведения о гребенчатошнуровой керамике вятско-ветлужской группы и обозначил ее отличия от нижнекамской ананьинской посуды (Марков, 2007).

Важные обобщения о характере, развитии, хронологии вятско-ветлужской культуры АКИО сделаны С.В. Кузьминых и А.А. Чижевским, которые убедительно доказывают, что носители ананьинской культуры гребенчатошнуровой керамики в бассейне рек Вятки и Ветлуги занимают обособленную территорию со своеобразной материальной культурой в рамках ананьинского мира (Чижевский, 2008; Кузьминых, Чижевский 2009; 2017).

В последнее время вопросы развития поселений АКГШК АКИО в бассейне р. Вятки рассматривает Э.И. Оруджов (2017а; 2017б; 2018; Оруджов, Глушков, 2019), который вслед за В.Н. Марковым, С.В. Кузьминых, А.А. Чижевским и другими исследователями АКИО пришел к выводу о близости населения, оставившего памятники в бассейнах р. Вятки и Ветлуги. Данный вопрос рассмотрим ниже.

Сейчас в бассейне р. Ветлуги известно всего 14 поселенческих памятников с типологически выделяемыми материалами РЖВ (рис. 2). Информация о некоторых из них содержится в археологической карте Нижегородской (Николаенко, 2013) и Костромской областей (Комаров, 1999). Материалы Пановской стоянки, где найдена сетчатая керамика, требуют изучения. Количество памятников подсчитано без учета поселений, зафиксированных в приустьевой части р. Ветлуги, имеющих свою обособленную культурную специфику и отличающихся от поселений основного течения р. Ветлуги в первую очередь широким кругом находок, связанных с акозинскими древностями. Поселения этого микрорегиона представлены на карте памятников начала РЖВ Марийского края (Патрушев, 2017б, рис. 1).

Т.Д. Николаенко на основании материалов археологической карты разделила памятники ананьинской культуры Нижегородского Поволжья по территориальному принципу, выделив две группы - Ветлужскую и ВолгоСурскую. К ветлужской группе отнесены пять памятников (Николаенко, 2016). Отметим, что в бассейне р. Ветлуги известно еще два памятника, соотносимых с РЖВ, - Подушкино 4 и городище Андреево 1 (по А.А. Пудееву), материал из которых не опубликован, хронология памятников не выяснена.

Таким образом, к настоящему времени в Поветлужье можно выделить только семь памятников с достоверно подтвержденными комплексами ананьинских древностей (Одоевское, Русенихинское, Богородское, Федоровское (Чортово), Шилихинское городища, Троицкое и 2 Богородское поселение). Заметим, что все эти памятники исследованы раскопами, для других поселений необходимы проведение полевых работ (раскопок) и пересмотр уже найденного при разведках материала, хоть и немногочисленного. Как правило, при разведочных работах обнаружена лепная заглаженная керамика и фрагменты посуды с сетчатой поверхностью. Характер многих поселений не определен.

Историю изучения памятников РЖВ бассейна р. Ветлуги можно разделить на четыре больших этапа, в основном она связана с исследованиями городищ, которые известны уже более ста лет, меньше внимания уделялось неукрепленными поселениям. Еще один важный аспект заключается в том, что материалы из раскопок до сих пор опубликованы весьма фрагментарно, что значительно затрудняет их корректную интерпретацию и сравнение.

История полевых исследований в регионе начинается со второй половины XIX века. Так, в 1866-1867 гг. А.П. и Н.П. Поливановы обследовали Богородское городище, а в 1894-1896 гг. XIX в. А.П. Поливановым на памятнике проведены раскопки, также обследованы Безводное поселение и Троицкое городище. В 1883 г. Ф.Д. Нефедов открыл Одоевское городище и провёл на нем раскопки, определив, что культурный слой состоит из трех горизонтов. К сожалению, добытая коллекция, по сведениям О.Н. Бадера, пропала (Бадер, 1951a, с. 110). В 1903 


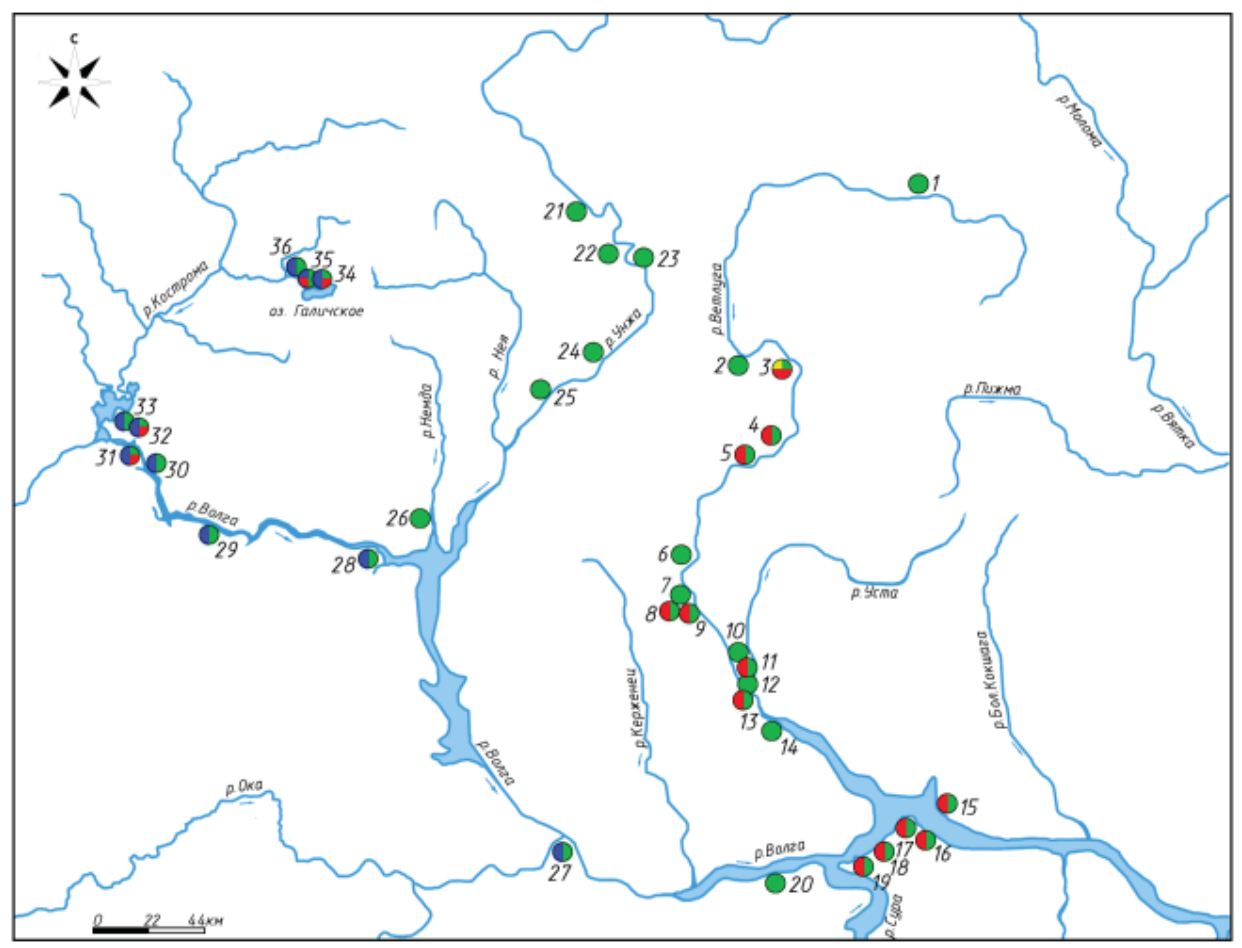

Рис. 2. Поселенческие памятники раннего железного века Поветлужья и ряда прилегающих районов Поселения бассейна р. Ветлуги: 1 - поселение Красноборы IV; 2 - Пановская стоянка (поселение Аксеново); 3 - Одоевское городище; 4 - Федоровское (Чортово) городище; 5 - Шилихинское городище; 6 - городище Селиваниха; 7 - поселение Подушкино II; 8 - II Богородское поселение; 9 - Богородское городище; 10 - Безводное поселение; 11 - Троицкое поселение; 12 - Троицкое городище; 13 - Русенихинское городище; 14 - Нагорное поселение; Основные поселения в приустьевой части p. Ветлуги и бассейна р. Волги: 15 - Ардинское городище; 16 - Малахайское поселение; 17 - Сиухинское городище; 18 - Копаньское городище; 19 - Васильсурское II городище; 20 - Сомовское II городище; Поселения бассейна рек Унжи и Немды:

21 - поселение Аверьяновка; 22 - Рапоновское городище; 23 - Поповское (Ухтубужское) городище;

24 - поселение Леонтьево; 25 - поселение Унжа II; 26 - поселение Хохлянки; Некоторые поселения с сетчатой керамикой и керамикой гибридных типов: 27 - поселение за Ромодановским вокзалом; 28 - Серюпитинское городище; 29 - Пеньковское

городище; 30 - Минское городище; 31 - городище в Костроме; 32 - поселение Ватажка; 33 - поселение Шунга; 34 поселение Быки (Пуп); 35 - городище Брюхово; 36 - городище Унорож.

- с комплексами АКИО; - с сетчатой керамикой и керамикой других типов (заглаженная, штрихованная), в т.ч.

неопределенных; - - керамикой гибридных типов; - с рамчатой керамикой «типа одоевского»

Fig. 2. Settlement sites of the Early Iron Age in the Vetluga Region and a number of surrounding areas Settlements on the Vetluga river: 1 - Krasnobory IV settlement; 2 - Panovskaya site (Aksenovo settlement); 3 - Odoevskoe hillfort; 4 - Fedorovskoe (Chortovo) hillfort; 5 - Shilikhinskoe hillfort; 6 - Selivanikha hillfort; 7 - Podushkino II settlement; 8 - Bogorodskoe II settlement; 9 - Bogorodskoe hillfort; 10 - Bezvodnoe settlement; 11 - Troitskoe settlement; 12 - Troitskoe hillfort; 13 Rusenikha hillfort; 14 - Nagornoe settlement

The main settlements in the estuarine part of the Vetluga river and the Volga river basin: 15 - Arda hillfort; 16 - Malakhai settlement; 17 - Siukhino hillfort; 18 - Kopan'hillfort; 19 - Vasilsursk II hillfort; 20 - Somovka II hillfort

Settlements in the basin of the Unzha and Nemda rivers: 21 - Averianovka settlement; 22 - Raponovo hillfort; 23 - Popovo (Ukhtubuzh) hillfort; 24 - Leontievo settlement; 25 - Unzha II settlement; 26 - Khokhlyanki settlement;

Some settlements with mesh and hybrid types of ceramics: 27 - settlement behind the Romodanovsky railway station; 28 -

Seriupitino hillfort; 29 - Penkovo hillfort; 30 - Minskoe hillfort; 31 - hillfort in Kostroma; 32 - Vatazhka settlement; 33 - Shunga settlement; 34 - Byki (Pup) settlement; 35 - Briukhovo hillfort; 36 - Unorozh hillfort.

- with complexes of the Ananyino Cultural and Historical Region; - with reticulate and other types of ceramics (smoothed, shaded), including undefined types; - with hybrid types of ceramics; - with framed ceramics of "Odoevo type"

г. небольшие раскопки на Одоевском городище произвел Бекаревич Н.М., материалы с раскопок им не датированы. Кроме того, Н.М. Бекаревич открыл Федоровское (Чортово) городище, раскапывавшееся в 1908 г. В.И. Каменским, и провел раскопки на Богородском и Федоровском городищах (Бадер, 1951a, с. 110-116; Новиков, 2018, с. 15-16).
На IV Областном Историко-Археологическом съезде в 1909 г. А.Н. Рождественский обобщил итоги деятельности Костромской архивной комиссии по раскопкам в губернии. В сводных данных он упоминает городище в с. Никола-Одоевское в Ветлужском уезде, а также сообщает еще об одном городище в Варнавинском уезде - Богородском. 
На этих памятниках членами комиссии проводились раскопки (Рождественский, 1909, с. 13).

Следующий важнейший этап в изучении памятников РЖВ Поветлужья - 20-е гг. ХХ века. В 1925-1926 гг. Научно-исследовательским институтом антропологии Московского университета была организована комплексная экспедиция в район рек Ветлуги и Унжи под руководством Б.С. Жукова, первый отряд которой возглавил О.Н. Бадер (Жуков, Бадер, 1925-1926; Бадер, 1951б, с. 15). Экспедицией выполнены антропологические, археологические, этнографические и лингвистические исследования, археологически изучены семь ветлужских и четыре унженских городища. Б.С. Жуков совместно с О.Н. Бадером провёл раскопки на Богородское городище, открыл Русенихинское, а совместно с Е.И. Горюновой исследовал Федоровское. Ценные материалы были получены в результате археологических раскопок Одоевского городища. О.Н. Бадер интерпретировал полученные материалы, определил хронологическую позицию и культурную принадлежность памятника (Бадер, 1951a, с. 114-134).

Очередной активный период изучения памятников АКИО в Поветлужье приходится на 50-е гг. XX века и связан с именами А.X. Халикова, Е.А. Безуховой, которые провели раскопки на Федоровском и обследовали Шилихинское городища, и В.Е. Стоянова, исследовавшего в 1958 г. Богородское, Русенихинское и Шилихинское городища. В.Е. Стоянов по результатам раскопок Русенихинского и Богородского городищ систематизировал керамические материалы ананьинского времени этого региона (Стоянов, 1959; Халиков, Безухова, 1960; Халиков, 1977, с. 241), датировав 2 и 3 слои Богородского городища VII-IV вв. до н. э. (Стоянов, 1959, с. 189-190).

Следующий этап в изучении древностей РЖВ Поветлужья начинается с 70-х гг. XX в. и продолжается вплоть до наших дней. Характеризуется он в основном обследованиями территорий, включая и получение новых данных о памятниках РЖВ. Во время разведок осмотрены известные памятники РЖВ, определено их техническое состояние. Открыты и новые памятники - городище Селиваниха 1 (Четвертаков Е.В.), Нагорное (Данилов О.В.), Троицкое (Никитина Т.Б.), Подушкино 2 и Богородское поселения (Пудеев А.А.). Раскопки в 2009 г. проводятся на Федоровском (Чортовом) городище Д.Ю. Ефремовой (Николаенко, 2013; 2016).
По результатам разведочных работ на памятниках обнаружены фрагменты сетчатой посуды и керамика других, часто неопределённых, типов. В частности, на поселении Красноборы IV собрана гладкостенная и штрихованная керамика, на Нагорном поселении и городище Селиваниха 1 - сетчатая керамика (возможно, акозинская), на поселении Подушкино 2 - керамика с примесями дресвы и шамота, на Богородском поселении - фрагменты глиняной посуды с минеральными примесями, орнаментированной гребенчатым штампом и клиновидными тычками, на Безводном не определена. В этот период происходят отдельные обследования памятников, что решает в основном локальные задачи, безусловно, очень важные, связанные с накоплением материала, но не решает генеральной, выраженной в систематизации и обобщении данных, от решения которой будет зависеть определение культурного статуса территорий и характера взаимодействия отдельных групп, носителей разных ананьинских традиций, в Поветлужье. Существует ареал культуры с периферией, на которой выделяются группы населения с традициями других культурных образований. На западных рубежах ананьинского мира таким регионом со смешанными культурными традициями выступает Поветлужье - регион, который располагается на стыке развития культур не только ананьинского круга, но и носителей сетчатых керамических традиций. В небольшом количестве распространяется на поселениях и керамика городецкого облика с рогожными отпечатками. Обзор культурного пространства показывает, что ядром АКИО в Поветлужье являлись Одоевское, Богородское, Русенихинское, Федоровское (Чортово) и Шилихинское городища.

Таким образом, материалы раннего железного века Поветлужья в настоящее время нуждаются в новой оценке, требуют изучения, полностью не разграничены, в связи с чем работа с имеющимися коллекциями по-прежнему актуальна. Многие материалы из исследованных к настоящему времени памятников РЖВ не введены в научный оборот, необходимо пересматривать, анализировать и корректировать схемы классификации керамики, предложенные более полувека назад, в связи с появлением новых данных и современным культурным подходом, применяемым в изучении ананьинских древностей.

Одной из отправных точек при рассмотрении материалов АКИО в регионе Поветлужья 
является наличие на памятниках собственно лебяжской посуды - важного звена в формировании типов ананьинской керамики вятско-ветлужской культуры (гребенчато-шнуровой керамики). Обращаясь к керамическим комплексам АКИО Поветлужья, можно отметить, что здесь выделяется посуда с лебяжскими признаками, выраженными в первую очередь в орнаментации посуды гребенчатыми оттисками (горизонтальные линии, зигзаги, наклонные отрезки), глазчатыми ямками (в т. ч. в сочетании с горизонтальной линией из оттисков гребенчатого штампа), украшении края косопоставленными оттисками гребенчатого штампа и формировании верхней части горшка с отогнутым низким краем. Именно такой край характерен для вятской керамики. Гребенчатые оттиски на керамике АКИО встречаются с достаточно широкой амплитудой шага, относительно большой ячейкой, как и на поселениях озъягского этапа лебяжской культуры (Буров, 1983, рис. 3: 11; Марков, 2007, рис. 28: 6, 29: 4, 5). Оттиски такого гребенчатого штампа известны и на посуде из Одоевского городища. Точное время появления лебяжских древностей на Ветлуге не определено. В.Н. Марков проникновение групп - носителей лебяжских традиций на Ветлугу относил к самому началу раннего железного века (Марков, 2007, c. 57). Сейчас лебяжская керамика известна только на Богородском городище (Стоянов, 1959, табл. LVI:10, LVII:14; Марков, 2007, рис. 29: 1-2) и на памятниках в приустьевой части Ветлуги - Ардинском городище и Малахайском селище (Марков, 2007, рис. 29: 3-4; Михеев, 2017, рис. 3: 7). Встречается лебяжская керамика и на памятниках Нижнего Прикамья, таких как Черепашье и Сухой Берсут (Марков, 2007). Основным элементом в орнаментации керамики лебяжского облика выступает зубчатый штамп, образующий сложные мотивы: двух-трех рядные горизонтальные линии, ряды наклонных и вертикальных отрезков, такая известна, в частности, в нижнем слое Сорочьегорского городища (Чижевский, Хисяметдинова, 2020, с. 195). А.А. Чижевский соглашается с мнением В.Н. Маркова, что такие детали орнамента характерны для озьягского этапа лебяжской культуры (Марков, 2007, Чижевский, Хисяметдинова, 2020). В.Н. Марков основное отличие лебяжской и собственно гребенчато-шнуровой керамики АКИО видел только в наличии шнуровых оттисков на последней, орнамен- тальные композиции при этом одинаковые (Марков, 2007, с. 56).

Отдельные вопросы возникают при рассмотрении посуды позднеананьинского периода из западных областей АКИО, включая бассейны рек Вятки и Ветлуги. Исключением является и керамика акозинской культуры АКИО, имеющая свои отличительные признаки, выраженные в текстильной обработке внешней поверхности, наличии минеральных примесей в формовочной массе, ямочном орнаменте (Чижевский и др., 2019, с. 134), специфические черты обнаруживаются и в морфологии горшков. Впервые на особенности акозинской культуры обратил внимание С.В. Кузьминых, который ее и выделил (Кузьминых, 1977, с. 138-139; 1983). Акозинская культура является частью огромного культурного мира текстильной керамики (Кузьминых, Чижевский, 2009, с. 34).

Не исключено, что наличие в Поветлужье горшков с высокой слабовогнутой шейкой, не характерных для вятских памятников, свидетельствует о возможном влиянии носителей акозинских керамических традиций. Весьма характерным элементом для посуды и ПМК АКИО является высокая прямая или слегка изгибающаяся шейка (Марков, 2007), а учитывая, что на рубеже VI-V вв. до н. э. происходит активизация продвижения в т. ч. и постмаклашеевских групп на северо-запад Восточной Европы (Кузьминых, Чижевский, 2017 , с. 26), вероятно, что в культурном взаимодействии на берегах р. Ветлуги принимают участие носители и этих ананьинских традиций, об этом свидетельствуют и некоторые особенности орнаментации посуды ветлужских памятников АКИО. В частности, В.Е. Стоянов отмечал наличие в раннем слое Богородского городища керамики, орнаментированной только ямками (Стоянов, 1959, с. 184), редко, но встречается подобная керамика и на Одоевском городище, в т. ч. с ямками и разреженными линиями из оттисков шнура. Часть ананьинских сосудов из Одоевского городища - с добавками в формовочную массу шамота. Минеральные примеси, в частности шамот, характерны для акозинской керамики из Ардинского городища. Такая посуда выделена здесь во вторую группу керамики, 95\% стенок которой покрыты текстильными отпечатками (Михеев, 2017, с. 35), что также может свидетельствовать о близких взаимоотношениях внутри ананьинского мира. Добавляется шамот и в сетчатую керамику из Одоевского городища. 
На поселениях Поветлужья известна сетчатая керамика с поверхностью, декорированной двумя типами отпечатков - нитчатыми и рябчатыми, при этом сетчатая керамика распространяется далеко вверх по течению р. Ветлуги и находится на памятниках в одних перемешанных слоях с керамикой вятсковетлужской культуры АКИО, например, на Одоевском и Богородском городищах.

Внешняя поверхность сетчатой керамики акозинской культуры АКИО декорировалась нитчатыми или рябчатыми отпечатками (Казанская стоянка, Маклашеевское II, Казанка I, Ардинское и Сиухинское городища) (Чижевский, Кузьминых, 2009, рис. 10; Ефремова, Соловьев, 2014, рис. 13; Патрушев, 2017а, рис. 3-6; Новиков, 2018, рис. 127-128; Чижевский и др., 2019, рис. 12; Чижевский, Хисяметдинова, 2020, рис. 166), что наряду с другими признаками определяет особенности акозинской керамики. Отличительно, что на Сомовском II городище посуда баночно-чашевидных форм в основном покрыта рябчатыми отпечатками (Никитин, Соловьев, 2001, с. 13). Сетчатая же керамика собственно с рябчатыми отпечатками является индикатором поселений РЖВ Посухонья и Верхней Волги (Новиков, 2019; 2020), и истоки керамики с рябчатыми отпечатками следует искать и в этом направлении, однако полные сравнения акозинской керамики (по степени превалирования тех или иных отпечатков на сосудах) сейчас затруднительны в связи с небольшим объёмом опубликованных материалов.

Появление носителей традиций изготовления сетчатой керамики на поселениях бассейна р. Ветлуги происходит в разное время. А.X. Халиков считал, что сетчатая керамика на Ветлуге появляется в результате проникновения Волго-Окского населения (Халиков, 1962, c. 12), и предполагал более раннее существование поселений с сетчатой керамикой в Поветлужье, предшествующих ананьинскому расселению (Халиков, 1962, с. 14). В.Е. Стоянов нашел сетчатую керамику, орнаментированную глубокими ямками, образующими выпуклины с обратной стороны, в первом догородищенском слое на Богородском городище (Стоянов, 1959, с. 162, 181), что также предполагает ее более раннее происхождение и характеризует процесс развития акозинских древностей или средневолжской культуры текстильной керамики эпохи поздней бронзы на Ветлуге. К памятникам с ранней сетчатой керамикой может быть отнесена Пановская стоянка (Аксеново поселение), на которой сетчатая керамика с прямыми шейками, выраженными плечиками и ямочным орнаментом, обнаружена вместе поздняковской посудой (Бадер, 1951б, с. 19). В то же время стратиграфическое положение находок остается неясным, и сетчатая керамика могла относится к акозинской культуре АКИО. В.С. Патрушев, картографируя памятники с «псевдосетчатой» керамикой эпохи бронзы и начала РЖВ в бассейне Ветлуги, отмечает только Богородское городище, а в приустьевой части - Ахмыловское поселение и Ардинское городище (Патрушев, 1989, рис. 6). По образцам нагара на «текстильной» керамике из Ахмыловского поселения и Ардинского городища получены даты (AMC) $2880 \pm 45$ и $2705 \pm 40$ соответственно (Лавенто, 2011, табл. 2). Анализируя сетчатую керамику из Ардинского городища, В.С. Патрушев приходит к выводу о наличии общих черт такой посуды с керамикой из поселений Средней Оки (Тюков Городок, Фефелов Бор I), отмечает и значительную близость сетчатой керамики Марийского Поволжья с комплексами такой посуды из поселений Костромского Поволжья (Патрушев, 2017a, с. 67). Выделяя особенности сетчатой керамики из поселений Средней Оки конца II - начала I тыс. до н. э., Л.Д. Сулержицкий и Б.А. Фоломеев указывают на орнамент, выполненный ямчатыми вдавлениями различных форм. Ямки располагались рядами. Оттиски гребенчатого штампа применяются крайне редко (Сулержицкий, Фоломеев, 1993, с. 28). Определенно близкая по стилю орнаментации керамика характерна и для многослойных поселений финала бронзы - начала РЖВ Костромского Поволжья (Новиков, 2020, с. $336-337,344 ; 2015$, с. 78). Ямки, расположенные по шейке рядами, типичны и для акозинской посуды (Чижевский и др., 2019, с. 134).

Следует обозначить одно кардинальное отличие сетчатой керамики финала бронзы - начального периода РЖВ из поселений Средней Оки и Верхней Волги: на окских памятниках в XI-VII/VI вв. до н. э. мелкие рябчатые отпечатки исчезают и преобладают нитчатые (Сулержицкий, Фоломеев, 1993, с. 28; Фоломеев, 2017, с. 329-330), в отличие от поселений Костромского Поволжья, на которых продолжают преобладать мелкоячеистые, хаотично расположенные рябчатые отпечатки на внешней поверхности керамики (Новиков, 2020, с. 345-346). Акозинская посуда (IX-VI вв. до н. э.) покрывается как рябчатыми, так и нитчатыми отпечатками. 
На памятниках с сетчатой керамикой Среднего Поволжья, начиная еще с эпохи поздней бронзы, встречаются и рябчатые, и нитчатые отпечатки. На особенности декорирования сосудов эпохи поздней бронзы из этого региона обратил внимание В.С. Патрушев. Он установил, что доля рябчатых отпечатков выше на керамике из Татарии и Нижегородского Поволжья (Патрушев, 1989, с. 33), такой же характеристикой обладает и керамика ранних памятников из бассейна рек Оки (Фоломеев, 2017, с. 329) и Верхней Волги. На сетчатой керамике из Марийского Поволжья незначительно, но преобладают нитчатые отпечатки (Патрушев, 1989, с. 33).

Сетчатая керамика, найденная на Одоевском городище, принципиально отличается от сетчатой посуды акозинской культуры АКИО. Керамика неорнаментированная, слабопрофилированная, в отличие от акозинской сетчатой керамики, для которой характерны ямки, образующие поясок под венчиком или на шейке, спускающиеся и ниже, и более выраженный переход шейки в выпуклые плечики. Только декорирование внешней поверхности как рябчатыми, так и нитчатыми отпечатками показывает определенную близость. Распространение сетчатой керамики на памятнике следует отнести ближе к середине I тыс. до н. э., третьей четверти I тыс. до н. э., учитывая и контекст нахождения единичных фрагментов сетчатой керамики в верхнем слое городища (Бадер, 1951a, с. 154), хотя имеется она и во втором слое (Жуков, Бадер, 1925-1926). Такая керамика близка посуде из поселений РЖВ Верхневолжского региона. Данные вопросы рассмотрим ниже. Зафиксирован в коллекции и один фрагмент с рогожными отпечатками.

Таким образом, в Поветлужье поселения с сетчатой керамикой известны, их взаимосвязь с памятниками вятско-ветлужской культуры АКИО, бесспорно, необходимо исследовать. Стоит обратить внимание на поселения бассейна р. Вятки, для которых керамика с сетчатой поверхностью не характерна, что позволяет говорить о большей обособленности и культурном единстве ананьинских коллективов, расселившихся по берегам p. Вятки, в отличие от ветлужских. Конечно, без внимания нельзя оставлять и географический аспект, однако взаимодействие с носителями сетчатых керамических традиций происходит по несколько иному сценарию, выраженному в проникновении носителей традиций вятско-ветлужской культуры АКИО на запад, в Посухонье и Верхнюю Волгу, в собственно традиционные районы поселений с сетчатой керамикой и довольно плотной интеграцией в сетчатый мир начиная с VI в. до н. э., что приводит к появлению нового культурного пространства со специфичной керамикой гибридного типа со смешанными сетчатыми и ананьинскими признаками.

В Костромском Поволжье для поселений со смешанными культурными традициями характерна керамика со шнуровыми оттисками, часто наложенными в несколько рядов, которые группируются в пояски, состоящие из двойных, тройных или четверных линий оттисков шнура и разделенные свободным пространством, вдавлениями или оттисками гребенчатого штампа. Часто встречаются и косички, выполненные из противоположно наклонных оттисков шнура, пояски из ямок, расположенных по шейке (встречаются и ямки, прорезающие ряды шнуровых оттисков), элементы орнамента, выполненные оттисками гребенчатого штампа (наклонные, прямые отрезки, зигзаги, горизонтальные линии), которые располагаются между линиями шнуровых оттисков или заканчивают композицию. Имеется и посуда с воротничком по краю и заглаженной поверхностью (поселение Ватажка). Зачастую поверхность гибридной керамики обработана сетчатыми отпечатками, как правило, рябчатой фактуры (Новиков, 2018). При ознакомлении с основными сюжетами орнаментации керамики Костромского Поволжья можно наблюдать явно уловимый след орнаментальной традиции именно вятско-ветлужской культуры (гребенчато-шнуровой керамики) АКИО. Конечно, специфика керамики будет отражать и сетчатые орнаментальные традиции (Новиков, 2018, с. 67). В VI-V вв. до н. э. ориентированность населения вятско-ветлужской культуры АКИО на запад и северо-запад будет определяющей, и носители этих ананьинских традиций окажут непосредственное влияние на население с сетчатой керамикой.

Сложный характер формирования и развития ВВК АКИО на пограничных западных территориях, в частности в Поветлужье, основанный на межкультурном взаимодействии, приводит к появлению и в этом регионе керамики гибридных типов. Совмещение разных традиций в рамках культур ананьинского мира на памятниках именно в приустьевой части р. Ветлуги достигает особой красочности. На Ардинском городище в небольшом количестве появляется гибридная керамика (Архипов, Патрушев, 1982, с. 55), гибридные 
сосуды известны на Васильсурском II городище и Токаревском поселении (Халиков, 1962, c. 104, 148-151). А.Х. Халиков предполагал, что такая посуда на Васильсурском II городище могла появиться уже в раннеананьинское время, в пользу этого свидетельствует и стратиграфический контекст ее обнаружения (Халиков, 1962, с. 151). Очевидно, что эти процессы характеризуют формирование и развитие акозинских древностей. На Ардинском городище в 2013 г. А.В. Михеевым собрана представительная коллекция акозинской сетчатой керамики, единична керамика городецкого облика с рогожным отпечатком, встречается и гибридная посуда с текстильными отпечатками и примесью раковины (Михеев, 2017, с. 37; Новиков, 2018, рис. 127-128). В.С. Патрушев также указывает на большой процент текстильной керамики, собранной при раскопках городища ранее, её количество достигает практически половины от всей посуды РЖВ (Патрушев, 2017a, с. 64). Не встречается гибридная посуда на поселениях, расположенных выше по течению p. Ветлуги. По всей видимости, ответ на вопрос о распространении такой керамики на памятниках Поветлужья может быть получен только после полного освещения материалов хотя бы с уже известных памятников и их анализа.

Определяя основные особенности керамики АКИО, исследователи в целом сходятся во мнении относительно морфологических признаков поселенческой посуды - это округлодонные горшки с вертикальными и отогнутыми шейками (низкими или высокими) и посуда закрытых чашевидных форм. Индикаторами посуды являются также примесь раковины, заглаженная поверхность, шнуровой и гребенчато-шнуровой орнамент. Для вятской керамики характерны низкие прямые или отогнутые венчики, воротнички и гребенчато-шнуровая орнаментация с преобладанием гребенчатой техники (Марков, 2007; Митряков, Черных, 2014), на Ветлуге преобладают цилиндрошейные сосуды с плавным переходом к тулову и горшковидные с плавно отогнутым горлом с раковинной примесью (Халиков, 1977, с. 241).

Прежде чем перейти к характеристике посуды из Одоевского городища, отметим, что все имеющиеся сравнительные типологии ананьинской керамики, построенные на особенностях верхней части сосудов, выглядят вполне логичными и обоснованными. Основные типологические схемы керамики АКИО разработаны по морфологическим признакам А.В. Збруевой, А.Х. Халиковым, В.Н. Марковым, В.С. Патрушевым, А.Г. Архиповым, Е.М. Черных, В.В. Ванчиковым, В.А. Шаталовым, Л.И. Ашихминой, А.Е. Митряковым (Збруева, 1952, с. 257; Халиков, 1962 , с. 143 ; 1977, с. 228-229; Марков, 2007, с. 17-26; Марков, 1988, с. 93; Патрушев 2017б, с. 113-115; Архипов, 1962, с. 201; Ашихмина, 2014, с. 22-23; Черных, Ванчиков, Шаталов, 2002, с. 29; Митряков, Черных, 2014, с. 175, 178).

В.Н. Марков для нижнекамской посуды выделяет четыре типа: 1. сосуды с сужающимся горлом; 2. сосуды с вертикальными или слабоотогнутыми горловинами; 3. среднеотогнутые и сильноотогнутые горловины; 4. без выраженной горловины, непрофилированные сосуды. Разновидности горловин: А с низкими; Б - со средневысокими; В - высокими (Марков, 2007, с. 17-26).

А.А. Чижевский, рассматривая мысовые городища Волго-Камья и определяя особенности керамической посуды АКИО, в частности с таких памятников, как Сорочьегорское, Гремячий Ключ, Черепашье, Сухой Берсут, обращается к схеме В.Н. Маркова (Чижевский, Хисяметдинова, 2020, с. 183, 194, $217,222)$, при этом отмечает и характерные особенности вятско-ветлужской керамики: сочетание в комплексах сосудов с гребенчато-шнуровой и гребенчатой орнаментацией, наличие многорядного шнура без разделителей, частое дополнение ямками (Чижевский, Хисяметдинова, 2020, с. 228). В дальнейшем А.А. Чижевский и Э.И. Оруджов выделяют специфические признаки вятско-ветлужской культуры АКИО: керамика чашевидной и горшковидной формы, украшенная гребенчато-шнуровым, гребенчатым, шнуровым и ямочным орнаментом; кельты типа КАН-90; широкое распространение в быту резных костяных изделий; использование в погребальном обряде одиночных погребений и «домов мертвых»; массовое применение кенотафов; бедность погребального инвентаря по сравнению с остальными культурами АКИО (Чижевский, Оруджов, 2021).

Несколько слов скажем и о двух ключевых типологических региональных схемах керамики, построенных М.В. Воеводским и В.Е. Стояновым (Воеводский, 1951, Стоянов, 1959) на основании анализа посуды из городищ Поветлужья (Одоевское, Богородское, Русенихинское, Чортово) и, соответственно, представляющих наибольший интерес при сопоставлении материалов Одоевского 
городища. В.Е. Стоянов проанализировал керамику из Богородского и Русенихинского городищ. На Богородском городище по форме верхних частей он выделил четыре типа сосудов, внутри каждого - подтипы А, Б, проследил развитие орнаментальных традиций (Стоянов, 1959, с. 179, 184-187). Многие мотивы орнамента посуды из Богородского и Русенихинского городищ присущи и керамике Одоевского городища.

В коллекции Богородского и Русенихинского городищ превалируют цилиндрошейные сосуды, но имеются и горшковидные с плавно отогнутым горлом. Редка посуда чашевидных форм. 95\% всей керамики изготовлено с примесью раковины в формовочной массе. Орнаментальные композиции сочетают элементы из шнуровых оттисков (в большинстве) и отпечатков гребенчатого штампа. Ямки часто нанесены поверх клиновидных вдавлений. Характерно наличие орнамента и по краю венчика. Выделена предананьинская керамика (Стоянов, 1959; Халиков, 1962; 1977). В одних слоях вместе с классической гребенчато-шнуровой ананьинской керамикой на Богородском городище обнаружена и лебяжская посуда. На одном фрагменте ананьинского горшка имеются оттиски гребенчатого штампа с замыкающимися в овал концами (Стоянов, 1959, табл. LVII: 11), что напоминает овально-вытянутый рамчатый штамп на керамике из Одоевского городища. Близкими гребенчатыми отпечатками поставлены крестики на одном ананьинском сосуде из Одоевского городища (рис. 12: 28).

В заключение обзора обратимся к типологическим разработкам М.В. Воеводского, но прежде отметим, что в них объединены сосуды разных культурно-хронологических типов. М.В. Воеводский, изучив и проанализировав керамику, найденную при раскопках городищ Поветлужья в 1925-1926 гг. (Одоевское, Богородское, Чортово, Русенихинское), составил классификацию ананьинской керамики Поветлужья, выделив три группы, отражающие, на его взгляд, последовательное развитие культуры «костеносных» городищ, при этом в основе лежит хронологическая шкала Одоевского городища со стратифицированным культурным слоем (Воеводский, 1951, с. 159-169). Сосуды первой группы в архаичных ее вариантах, по мнению Воеводского М.В., находят аналогии в ранних памятниках ананьинской культуры. Вторая группа близка керамике позднеананьинских и пьяноборских древностей. Керамика более поздних групп имеет новые, явно местные, черты, все более отличается от Прикамья (Воеводский, 1951, с. 169-170). Исследователь считал, что начиная c IV-III вв. до н. э. на поселениях Ветлуги происходят значительные изменения в керамике. Во-первых, появляются минеральные примеси в тесте, во-вторых, отмечается уменьшение орнаментированных зон. Шнуровой орнамент представлен слабо, на орнаментальном фоне остаются чистые поля (Воеводский, 1951, с. 160-169). Появляется сетчатая керамика.

Подводя итог своим наблюдениям, М.В. Воеводский выделяет три основных момента в развитии керамики: 1. смена круглодонных сосудов на плоскодонные; 2. раковинная примесь заменяется дресвой и шамотом; 3 . происходит упрощение и уменьшение орнамента со 100\% до 10-15\% (Воеводский, 1951, c. 168-169).

На кардинальные отличия керамики из нижнего и верхнего слоёв, выраженные в практически полном отсутствии орнамента, примеси дресвы в тесте, плоскодонности у керамики из верхнего горизонта, указывал и О.Н. Бадер (1951б, с. 30).

Стоит заметить, что, когда О.Н. Бадер и М.В. Воеводский говорили об изменениях в орнаментации керамики, а точнее об упрощении сюжетов, они имели в виду всю керамику, найденную на памятнике, не разделяя её на культурно-хронологические типы. В таком случае схема обеднения орнамента легко просматривается. Однако необходимо исключить из этой схемы комплекс керамики с т. н. рамчатым декором. Керамика этого типа, как правило, со сложными орнаментами. Нужно обратить внимание и на керамику с простым орнаментом, составленным из разреженных рядов шнуровых оттисков и поясков из ямок (вдавления в т. ч. подтреугольные, клиновидные и др.), расположенных по шейке и плечикам, которая встречается в постмаклашеевских комплексах. Также следует отметить, что неорнаментированная керамика чашевидных форм с примесями раковины присутствует в комплексах посуды раннеананьинских памятников, имеется и небольшой процент посуды, орнаментированной только ямками. Керамика, украшенная ямками, на Богородском городище характерна именно для нижних слоев (Стоянов, 1959). В свою очередь, неорнаментированная штрихованная и заглаженная керамика с примесями шамота относится к следующему культурно-хронологическому пласту и не является развитием 
ананьинской керамики. О.Н. Бадер уже указывал на смену населения на городище (Бадер, 1951a), поэтому проследить тенденцию упрощения орнаментальных композиций именно на ананьинской керамике из Одоевского городища достаточно сложно, но она фиксируется; на этих моментах подробнее остановимся ниже при характеристике посуды.

Прежде всего, скажем несколько слов о стратиграфии Одоевского городища. О.Н. Бадер достаточно подробно рассматривает ее особенности в своей работе. Нижний, третий слой он отнес к раннеананьинскому времени, датировав его VII-V вв. до н. э., следующий за ним, второй, датирован IV-I вв. до н. э., верхний слой городища отнесён исследователем к началу нашей эры. Определяя верхнюю дату памятника III в. н. э., О.Н. Бадер отмечал, что керамика с памятника близка керамике с позднедьяковских городищ более западных районов Поволжья (Бадер, 1951a, с. 151-155; 1951б, с. 31).

Судя по рисункам профилей раскопа, представленных О.Н. Бадером, слои на городище зачастую перемешаны, и очевидно, что их стратиграфическая последовательность нарушена, соответственно, и фрагменты посуды могли быть неоднократно переотложены в культурном слое. О.Н. Бадер указывает, что слои 2 и 3 культурно и стратиграфически связаны друг с другом, представлены фрагментарно и практически не сохранились на площадке городища (Бадер, 1951a, с. 121). Так, слой 3 прослежен только на участке III/8 и III/9, а, г, д, е, и отделен от второго слоя тонкой глинистой прослойкой. Найдено в нем лишь небольшое количество керамики (Бадер, 1951a, с. 118; 1951б, рис. 3). Фиксируется слой 3 рядом со склоном и на склоне площадки городища. Согласно первичной коллекционной описи, в самом нижнем горизонте кроме керамики найдены камни, куски обожженного гранита, обломок кости. Керамика из 3 слоя представлена фрагментами с рамчатым штампом, ананьинской, включая и сосуды, украшенные гребенчатыми оттисками с широкой амплитудой шага, обнаружен и один фрагмент керамики с расчесами, характерный для 1 слоя (Жуков, Бадер, 1925-1926). Слой 2 сохранился несколько лучше (Бадер, 1951a, рис. 7-10). Здесь необходимо подчеркнуть, что практически весь участок III располагался на площадке, примыкавшей к склону, и непосредственно по склону террасы (Бадер, 1951a, рис. 7). Культурные слои, вероятно, сползали, перемешивались, скидывались при расчис- тке площадки городища и т. п., происходило и механическое смешение находок. Заметим, что площадка городища долгое время распахивалась и на ней велась хозяйственная деятельность. О.Н. Бадером также отмечалось, что на срытой вершине вала стоит ветхая часовня (Бадер, 1951a, с. 114, рис. 3). Б.С. Жуков представил описание поверхности площадки городища в кратком отчёте за 1925 г. как довольно сильно «изуродованную», указав и на вал, который в средней части несколько срыт, и на этом месте стоит старая часовня (Жуков, Бадер, 1925-1926). Судя по рисункам и описаниям О.Н. Бадера, слой 1 перекрывает слой 2 и отделяется от него, по крайне мере граница слоя определяется (Бадер, 1951a, с. 120, рис. 10), но повторимся, что зафиксировано это в основном рядом со склоном и по склону городища. Таким образом, находки в слоях Одоевского городища переоткладывались, и первоначальное стратиграфическое расположение многих из них, весьма вероятно, изменено.

М.В. Воеводский всю керамику из третьего и второго слоёв связывал с АКИО вслед за О.Н. Бадером, который датировал ветлужские городища первого периода VII-V вв. до н. э. (Бадер, 1951a, с. 151; Бадер, 1951б, с. 22). Для второго слоя О.Н. Бадером предложены датировки в рамках IV-III или IV-I вв. до н. э. (Бадер, 1951а, с. 152; Бадер, 1951б, с. 28). В нижнем (третьем) слое Одоевского городища найдены сосуды с глазчатыми ямками (Воеводский, 1951, рис. 1), керамика с преобладающим шнуровым орнаментом в сочетании с гребенчатыми оттисками и ямками (Воеводский, 1951, с. 160). Описываемые орнаментальные сюжеты явно указывают на керамику вятско-ветлужской культуры АКИО. В то же время на памятнике типологически выделяется еще одна группа керамики с т. н. рамчатым штампом и примесью раковины. Находилась она в одних культурных слоях (слои 2-3) вместе с керамикой ананьинского типа, по-видимому, переоткладывалась и в более поздний слой 1 , учитывая особенности стратиграфии на месте исследований, о которых говорилось выше. Вероятнее всего, авторы полевых исследований и М.В. Воеводский не увидели различий в комплексах керамики с рамчатым штампом и собственно ананьинской вследствие наличия ряда сближающих их признаков, а именно: аналогичными примесями в формовочной массе (раковина), хорошо заглаженной поверхностью, толщиной стенок (сосуды тонкостенные), близкими орнаментальными сюжетами и морфологиче- 
скими особенностями верхней части посуды. В связи с этим М.В. Воеводский не выделил ее в отдельный тип и принял за ананьинскую, описав керамику суммарно.

Таким образом, данная типологическая схема перестает быть надежной и должна быть откорректирована, безусловно, с учетом рекомендаций, составленных М.В. Воеводским.

В предложенной М.В. Воеводским схеме группы и типы керамики зависят от общих наблюдений за изменениями отдельных деталей (морфологических, орнаментальных, технологических) и появлением новых признаков на всей имеющейся керамике, которые применяются для классификации и являются основанием для выделения непосредственно самих групп и подтипов внутри них, а также переходят из одной группы в другую, не вычленяясь в зависимости от культурнохронологических типов керамики (сетчатая, заглаженная, штрихованная, гребенчатошнуровая, с рамчатым штампом или другая), что, несомненно, оставляет ещё много поводов для дискуссии.

Рассмотрим еще один интересный, на наш взгляд, момент. В четвертом, древнейшем, слое, исследованном в примыкании к склону городища на участках III 2-5 (Бадер, 1951a, рис. 7), найдены только каменные предметы. К этому слою, на взгляд О.Н. Бадера, должна быть отнесена и большая часть находок из камня, полученных при раскопах памятника Ф.Д. Нефедовым, а также описываемые им очаги (Бадер, 1951a, с. 121). На наш взгляд, допустимо соотнести с четвёртым слоем и типологически выделяемый комплекс керамики с рамчатым штампом, который оказался смешанным в культурных слоях вместе с керамикой вятско-ветлужской культуры АКИО. Конечно, пока это только гипотеза. Чтобы оценить стратиграфическое расположение отдельных типов керамики, необходимы новые полевые исследования, сейчас мы располагаем недостаточными сведениями о стратиграфии памятника. Не бесспорным остается и стратиграфический контекст сетчатой посуды, найденной в разных слоях. Остаётся открытым и неисследованным и важный вопрос времени строительства укреплений.

Итак, приступим к характеристике керамической посуды, обнаруженной на памятнике Б.С. Жуковым и О.Н. Бадером. Выделяющиеся типологически и не связанные между собой комплексы керамики рассредоточены в трех культурных слоях.
Керамические комплексы

При исследованиях памятника в середине 20-х гг. ХХ в. получена представительная коллекция находок из глины, камня, кости и металла. Находки хранятся в ГБУК Нижегородской области «Нижегородский государственный историко-архитектурный музейзаповедник». Автор выражает благодарность Шакуловой Л.Д. за помощь при работе с коллекциями в фондах ГБУК НО НГИАМЗ. Коллекция под номером ГОМ (Горьковский областной музей) 4008, 4009, 4010. Общее количество находок по книге поступлений составляет 3196 шт. Сохранились и первоначальные описи предметов, составленные Б.С. Жуковым (1925 г.) и О.Н. Бадером (1926 г.) (Жуков, Бадер, 1925-1926, приложение к ГОМ 4008-4010).

Коллекция керамики фрагментирована, целых форм сосудов нет. Всего в обработку попало около 3000 фрагментов измельченной керамики. Анализ керамического материала позволил выделить несколько групп посуды с различными признаками. Оказалось затруднительно разделить фрагменты неорнаментированных стенок с примесью раковины в формовочной массе, которые могут относится как к керамике с рамчатым декором, так и к вятско-ветлужской культуре АКИО.

Технологический анализ керамики выполнен м.н.с. ГБУК НО НГИАМЗ А.А. Швецовой (прил. 1): отобраны фрагменты сетчатой керамики, керамики с рамчатым декором (включая развалы сосудов) (рис. 3: 14; 4: 4, 13) и наиболее характерной керамики вятсковетлужской культуры АКИО (обломки посуды, орнаментированной только гребенчатыми оттисками, в т. ч. с широкой амплитудой шага; с простым орнаментом, составленным из линий шнуровых оттисков в сочетании с поясками из вдавлений; со сложными орнаментальными композициями, сочетающими несколько техник исполнения (гребенчато-шнуровая (включая посуду с глазчатыми ямками), гребенчатая с вдавлениями (сосуд с воротничком), а также керамика, украшенная шнуровыми оттисками и ямками, образующими выпуклины с внутренней стороны)) (рис. $8: 22,23 ; 9: 4,18,25 ; 10: 6,15,17 ; 11: 25 ; 12$ : 28).

По верхней части может насчитываться 237 сосудов различных типов (керамика с рамчатым штампом, вятско-ветлужской культуры АКИО и сетчатая). В данный подсчет не включена постананьинская керамика IV технологической группы (прил. 1), характеризующая 


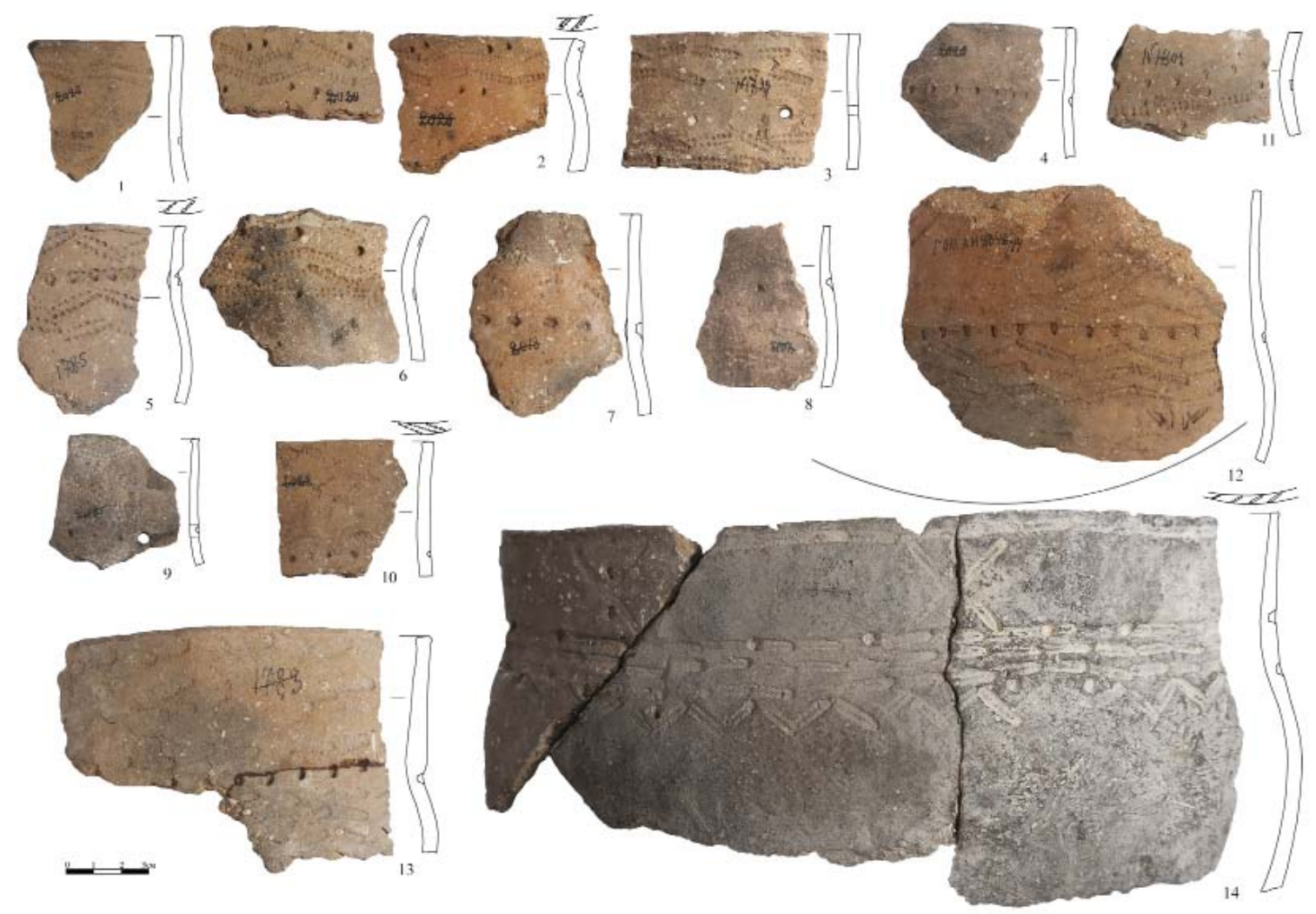

Рис. 3. Керамика с рамчатым декором «одоевского типа»

Fig. 3. Ceramics with a framed decor of "Odoevo type"

первый (верхний) слой городища. Технологический анализ также показал ее кардинальное отличие от керамики предананьинского и ананьинского времени. Вне зависимости от характера обработки внешней поверхности (заглаженная или штрихованная) керамика изготавливалась из среднезапесоченной глины с добавлением минеральной примеси шамота и органических компонентов. Такая посуда занимает значительное место в коллекции, и ее доля среди всей фрагментированной керамики составляет $30 \%$. Отметим только, что среди этой посуды преобладает керамика с заглаженной поверхностью. Среди штрихованной выделяется посуда с четкими штрихами (бороздки глубокие) и расчёсами, напоминающими штрихи. Возможно, носители штрихованной керамики появляются на памятнике уже в конце I тыс. до н. э.

1. В первую группу выделен комплекс керамики с заглаженной поверхностью и рамчатым декором (рис. 3-6). Керамика орнаментирована: 1) только рамчатым штампом; 2) рамчатым штампом в сочетании с ямками; 3) рамчатым штампом, гребенчатыми оттисками и вдавлениями (гибридная). Комплекс представительный, керамика этой группы найдена в слоях вместе с ананьинской посудой и в основном соотносится с нижними горизонтами -2 и 3, возможно, переоткладывалась и в более поздний слой. В эту группу может быть включено 62 горшка, определенных по фрагментам верхних частей, считая и гибридную посуду. Внутренняя и внешняя поверхности заглажены. Иногда внутренняя поверхность слегка подштрихована. Техника орнаментации - рамчатый штамп, вдавления, гребенчатые оттиски (на гибридной посуде). Оттиски рамчатого штампа - с замкнутыми концами, чаще всего четко вдавленные, встречаются и слабовдавленные, едва заметные. Выделяются оттиски узкого и широкого рамчатого штампа. Форма отпечатков преимущественно овально-вытянутая, встречается и вытянутая с приостренными краями (листовидная). Штамп чаще средних размеров, редко наносятся длинные оттиски. В одном случае зафиксирован совсем короткий штамп подквадратной формы, составленный из оттисков только двух парных зубцов (рис. 5: 19; 6; 13). На двух горшках нанесены оттиски подпрямоугольного штампа. На одном сосуде сочетаются отпечатки рамчатого штампа подпрямоугольной и овально-вытянутой формы (рис. 3: 12). Встречается штамп плотный, с часто поставленными зубцами, и разреженный, с бо́льшими промежутками между ними. Сами зубцы подквадратной формы, реже вытянутой подпрямоугольной. При орнаментации оттиски рамчатого штампа, как правило, плотно 


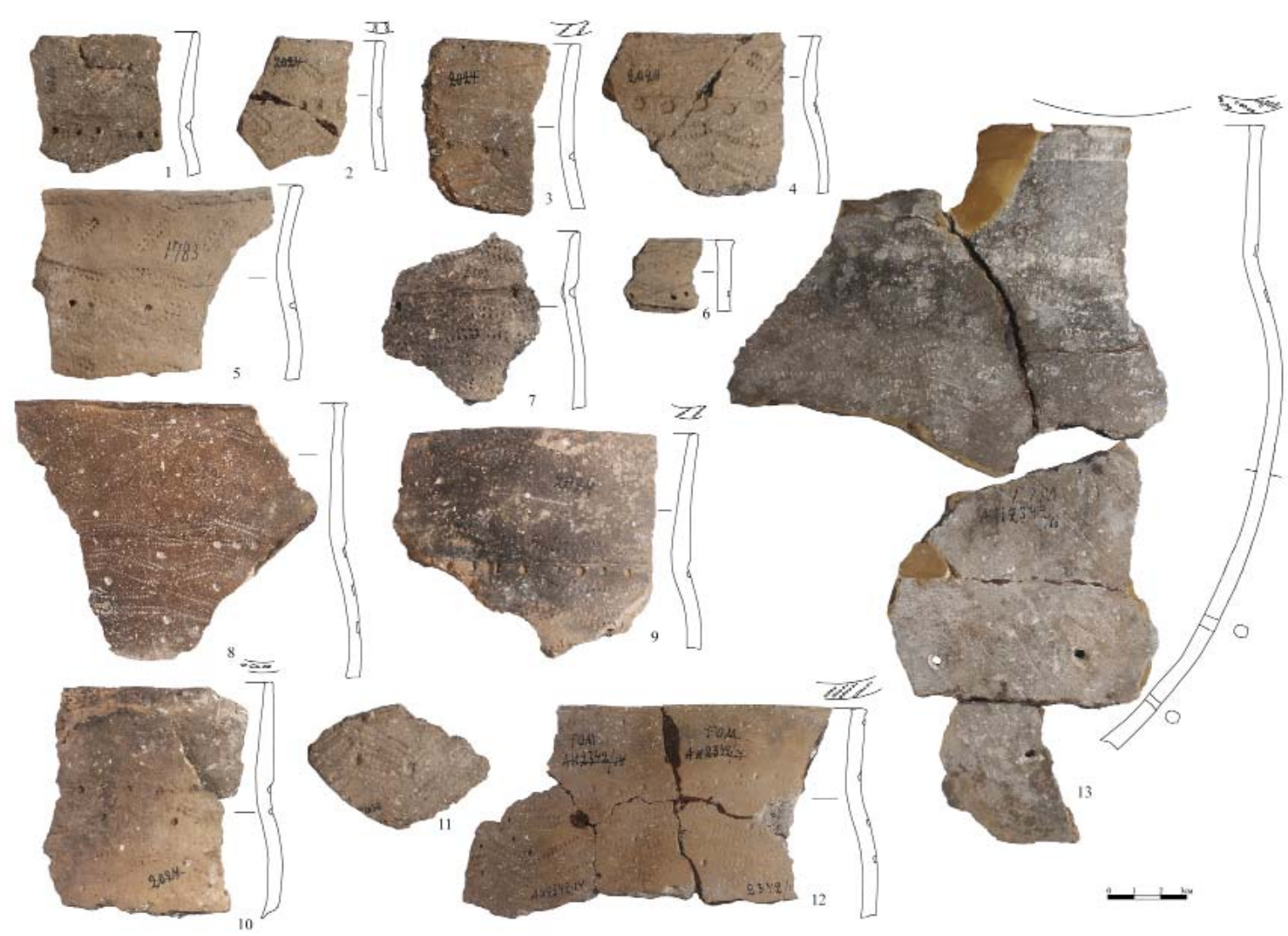

Рис. 4. Керамика с рамчатым штампом «одоевского типа»

Fig. 4. Ceramics with a framed stamp of "Odoevo type"

примыкают друг к другу, редко можно наблюдать керамику с промежутками между ними (рис. 5: 19; 6: 7). Толщина стенок этой группы керамики от 0,3 до 0,65 см, в среднем $0,4-0,5$ см. Цвет керамики - серо-коричневых оттенков, нередко и более светлых цветов - светло-коричневого, рыжевато-коричневого. Для изготовления сосудов использовалась незапесоченная, условно пластичная ожелезненная глина. В формовочную массу добавлялась раковина моллюсков, при этом предварительно нагретая на углях (прил. 1).

По морфологическим особенностям верхней части выделяется посуда трех видов: 1. Плавнопрофилированные сосуды горшковидной формы с отогнутым наружу краем, плавно вогнутой средней по величине шейкой и округлыми или слабовыпуклыми плечиками. На горшке этой же группы отмечен край в виде слегка скошенного наружу бортика (рис. 3: 2). У одного сосуда присутствует воротничок (рис. 4: 1). Выделено только 6 сосудов этого вида (рис. $3: 2,11 ; 4: 4,5 ; 5: 10,28$ ); 2. Слабопрофилированная с прямой подцилиндрической (или слабонаклонной наружу) шейкой, приспущенными слабовыпуклыми или выпуклыми плечиками (посуда этой формы доминирует в коллекции и представлена 48 экземплярами). Переход к плечикам плавный. Шейка чаще высокая, средняя по величине и низкая встречаются реже. Диаметр двух сосудов этого типа равен примерно 36 и 25 см (рис. 3: 14; 4: 13). Посуда этой группы по краю декорируется и воротничком; 3. Редко встречается посуда с отогнутой наружу, практически прямой шейкой и относительно резким переходом к плечикам. Выделено только два сосуда этого вида (рис. 3: 6; 6: 12).

Степень выпуклости плечиков определена не у всех сосудов: коллекция фрагментарна, и плечико у многих сосудов обломано.

Посуда округлодонная. Край посуды чаще всего плоский (47\%), иногда плоский край имеет небольшие Т- (17\%) или Г-образные (7\%) наплывы. Редко скошен наружу (2\%) или внутрь (2\%). У 25\% сосудов край округлый. Довольно часто на сосудах второй группы формируется воротничок. Присутствует он и на посуде первой группы. Выделено 12 сосудов с воротничком, включая и гибридную керамику (рис. $3: 5,12,13 ; 4: 1,4,7-10 ; 5: 11$, $15 ; 6: 22)$. Воротничок, как правило, высокий, нередко слабовыраженный (невыразительный). Низкий ворот встречается реже (рис. $3: 5 ; 4: 7 ; 5: 11 ; 6: 22)$, он же присутствует и на гибридной посуде. 19 горшков (или 30\%) орнаментированы по краю венчика (из них один сосуд гибридный), как правило, косопоставленными оттисками гребенчатого штампа, что свойственно лебяжской, а потом и 


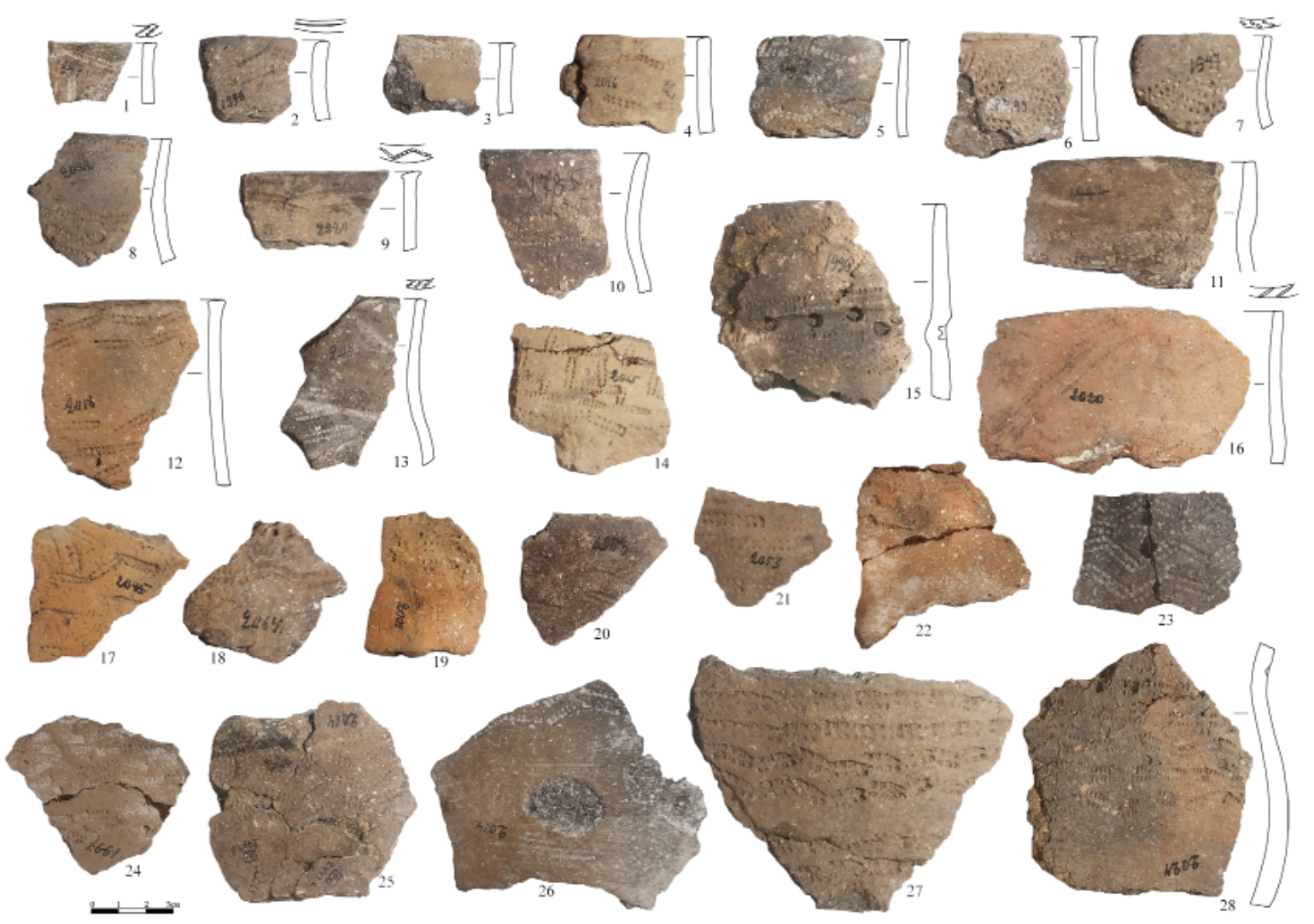

Рис. 5. Керамика с рамчатым штампом «одоевского типа»

Fig. 5. Ceramics with a frame stamp of "Odoevo type"

ананьинской керамике, или оттисками рамчатого штампа (рис. 3: 2), на одном горшке зафиксирован зигзаг из оттисков гребенчатого штампа (рис. 5: 9). У двух сосудов наблюдаются косые нарезки (рис. 5: 16), а у одного прочерченная по кругу линия (рис. 5: 2).

Орнамент нанесён от края, по шейке и плечикам сосудов. Элементы орнамента плотно располагаются друг к другу, неорнаментированное пространство между отдельными мотивами минимально. Как особенность можно выделить разреженность орнамента в средней части шейки, когда между мотивами остаются достаточно широкие чистые неорнаментированные зоны (рис. $3: 1,3,12,14 ; 4: 1$, $3-5,8-10,12-13 ; 5: 3-5,8,11-12 ; 6: 3,7,9-10$, $13-15,17-18)$, при этом наиболее густо орнаментируются нижняя часть шейки и место перехода к плечикам. Мотивы орнамента, выполненные рамчатым штампом, представлены горизонтальными линиями, зигзагами, крестиками, ромбами, лапками водоплавающих, поясками из наклонных оттисков. При орнаментации наиболее характерен зигзаг. Нередко сюжет из многорядного зигзага напоминает вертикальную ёлочку (рис. 3: 13). В отдельных случаях зигзаги образуют ромбы. Весьма оригинальным сюжетом отличается один горшок, на котором отпечатки рамчатого штампа образуют знак «Ү», расположен- ный в горизонтальном положении (рис. 3: 13). Наиболее распространен в орнаментации зигзаг (одно- или двухрядный, реже более), чаще всего им и начинается орнаментальная композиция. Встречается и зигзаг с небольшим наклоном оттисков (низкий зигзаг) (рис. $3: 1,3 ; 5: 4,27 ; 6: 10,18)$. Мотивы, выполненные рамчатым штампом, дополняются и горизонтальными рядами из ямочных вдавлений: ямки нанесены достаточно плотно и через приблизительно одинаковые интервалы, округлые вдавления при этом неглубокие и редко образуют выпуклину с обратной стороны. Очень редко наносятся подтреугольные или клиновидные вдавления, имеются сквозные отверстия, встречаются и мелкие ямки. Дно ямок - кольцеобразное, плоское, реже коническое и с сужающимися к округлому дну стенками, при этом ямки с округлым и коническим в сечении дном в основном характерны для первой группы плавнопрофилированных сосудов. Редко ямки образуют выпуклины с обратной стороны стенок (рис. $3: 5,7 ; 6: 25$ ). Пояски из ямок в основном делаются в нижней части шейки, подчеркивают и переход шейки в плечики, а также выделяют воротничок (рис. 3: 1, 4, 5, 7-13; 1-10, 12-13). Второй ряд ямок присутствует нечасто, при этом выделим любопытную особенность: расстояние между ямками второго ряда увеличивается (рис. 3: 
$6,11 ; 4: 10,12-13)$ в отличие от достаточно плотно поставленных ямок первого ряда, в одном случае ямки сгруппированы по две. По плечикам ямки ставятся реже, у одного сосуда зафиксированы сквозные отверстия на тулове. Что характерно, по шейке наносятся ямки и на горизонтальные линии, составленные из оттисков рамчатого штампа (рис. $3: 6,14 ; 4$ : $3,8,10)$.

Начинается орнаментальная композиция на посуде второго и третьего типа практически всегда горизонтальной линией или зигзагом из отпечатков рамчатого штампа, расположенным под венчиком. Редко в верхней части шейки наблюдается поясок из наклонных отпечатков рамчатого штампа, начинающих орнаментальное поле (рис. 3: 12; 5: 6, 15-16). У сосудов первого типа композиция может начинаться ямочными вдавлениями (ямки спаренные), нанесенными поверх зигзагов (рис. 3: 2), крестиками (рис. 4: 4) или наклонными оттисками рамчатого штампа, образующими поясок (рис. 4: 5), зигзагами (рис. 5: 10), у двух горшков этого типа верх обломлен.

Из наиболее полно представленных и интересных орнаментальных композиций на сосудах этого типа можно выделить следующие.

Сосуд 1 (рис. 3: 12). Отмечается любопытное совмещение длинных подпрямоугольных и овальных оттисков рамчатого штампа, из которых составляется зигзаг. Композицию начинают наклонные длинные отрезки, расположенные по шейке от края сосуда, ниже нанесён однорядный зигзаг, под которым находится горизонтальный ряд из клиновидных и подтреугольных вдавлений, выделяющий воротничок. Слабовыпуклые плечики украшены трехрядным зигзагом. Заканчивают композицию спаренные V-образные фигуры, напоминающие траву. Фрагмент найден в нижнем слое на участке Р. Сосуд 2 представлен развалом (рис. 3: 14). Орнамент выполнен овальными короткими оттисками рамчатого штампа. Композиция выглядит следующим образом: у самого края сосуда расположена горизонтальная линия, ниже шейка украшена горизонтальным пояском из Х-образных крестиков с двумя ямками, находящимися сверху и снизу от перекрестия. В нижней части шейки нанесены три горизонтальные линии. Поверх первого ряда, составленного из оттисков рамчатого штампа, выполнены ямки с плоским дном. Под горизонтальными линиями нанесены спаренные ямки, расположенные на большом расстоянии друг от друга, замыкает композицию однорядный зигзаг, размещенный на плечиках. Развал этого сосуда зафиксирован в слое 2 на участке Ч. Сосуд 3 также представлен развалом (рис. 4: 13). Мотивы орнамента выполнены овальными слабовдавленными, средними по размерам оттисками рамчатого штампа. Композиция представлена горизонтальными линиями, чередующимися с однорядным зигзагом и пояском из ямок, расположенным в нижней части шейки. Поверх линии из оттисков рамчатого штампа, расположенной на переходе шейки в плечико, поставлены ямочные вдавления. Второй ряд из ямок расположен на плечиках, при этом расстояние между ямками большое. Ямки неглубокие с плоским дном. Орнаменту отведено место по шейке и плечикам. На тулове этого горшка имеются сквозные отверстия. Найдены фрагменты керамики на уч. III/11 в нижнем слое. Сосуд 4 (рис. 4: 8) орнаментирован длинными овальными оттисками рамчатого штампа. По шейке сделаны два одинарных горизонтальных зигзага, между которыми нанесены наклонные отпечатки рамчатого штампа, при этом на шейке остается много неорнаментированного пространства. На месте перехода шейки в плечико выполнена горизонтальная линия, поверх которой поставлены ямки, сгруппированные по три. Плечики орнаментированы однорядным зигзагом, ниже которого устроен горизонтальный ряд из ромбов с ямкой посередине (ямки неглубокие, с плоским дном). Заканчивается композиция оттисками рамчатого штампа со слабым наклоном, образующими низкий зигзаг, в основании которого нанесены ямочные вдавления. Найден фрагмент в нижнем слое. Сосуд 5 (рис. 4: 12) орнаментирован длинными овальными оттисками рамчатого штампа. Орнамент начинается сразу под краем и представлен однорядным зигзагом, который оконтурен снизу мелкими ямочными вдавлениями. В нижней части шейки и на месте перехода в плечики расположен поясок из мелких ямочных вдавлений, при этом ямки поставлены не строго по горизонтали (одна из них может быть выше или ниже другой). Ниже ряда из ямок нанесены два горизонтальных ряда из рамчатых оттисков. Плечики украшены двурядным зигзагом, оконтуренным мелкими вдавлениями, завершает композицию горизонтальная линия из оттисков рамчатого штампа. Состоит из обломков, найденных в нижнем слое на уч. В.

Гибридная керамика (рис. 5: 14; 6: 22-27)

Керамика найдена в нижнем культурном слое, при этом два фрагмента находились в 


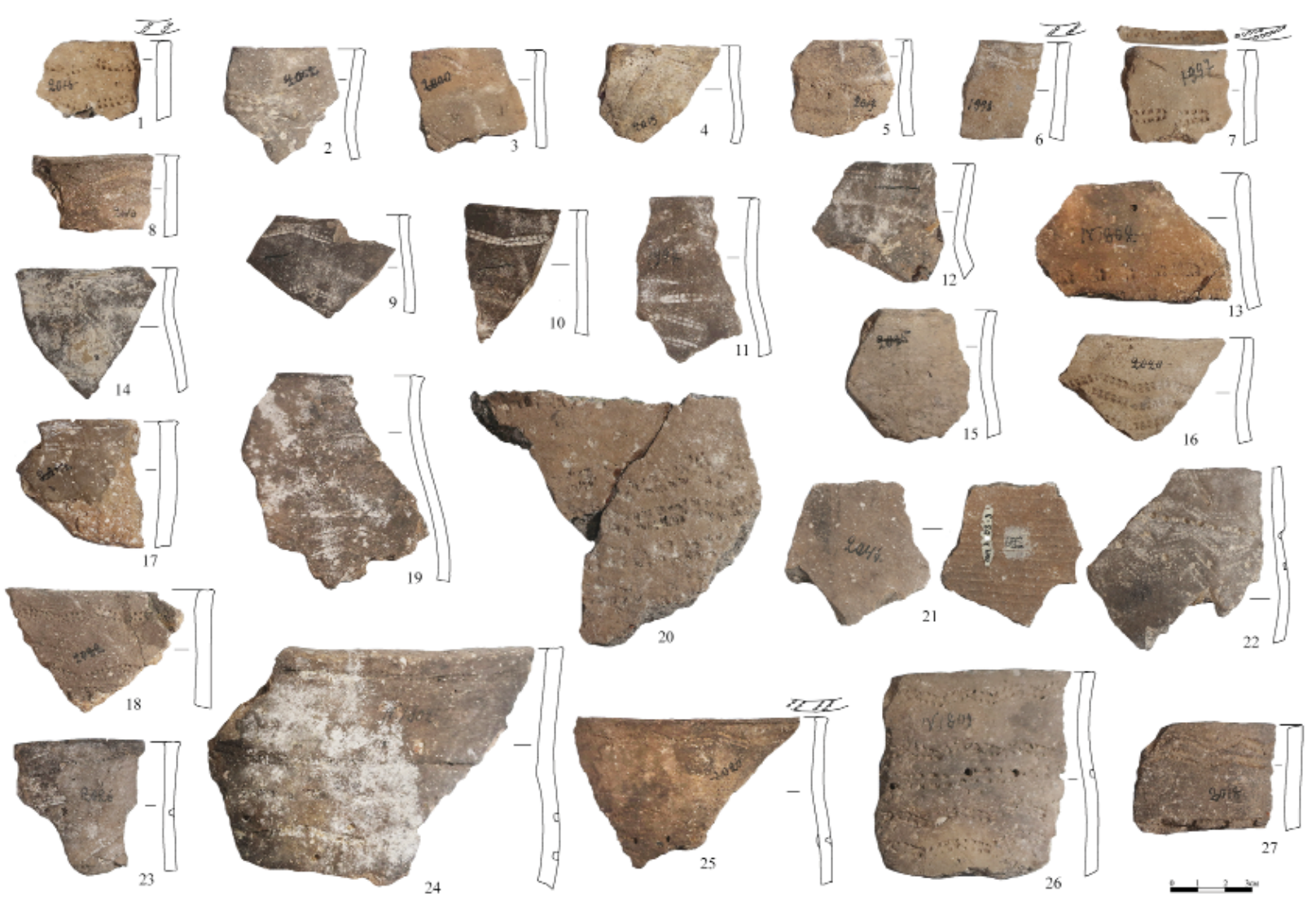

Рис. 6. Керамика с рамчатым декором «одоевского типа» (1-21) и гибридная керамика (22-27)

Fig. 6. Framed decored ceramics of "Odoyevo type" (1-21) and hybrid ceramics (22-27)

нижнем слое 3 , один из них - на участке $\mathrm{H}$, в очаге (рис. 6: 26). Посуда слабопрофилированных форм с прямой или слабоотогнутой наружу шейкой и слабовыпуклыми плечиками. В коллекции насчитывается 6 сосудов, выделенных по верхней части. Один сосуд имеет небольшой ребристый выступ с внутренней стороны на месте перехода шейки в плечики (рис. 6: 24). Такой выступ характерен для посуды маклашевского облика. Два горшка с приплющенным плоским краем, имеющим небольшие Т-образные оттяжки. Край еще трех сосудов плоский, из них у одного слегка скошен внутрь. У одного сосуда край оформлен в виде воротничка. По краю одного сосуда нанесены косые оттиски гребенчатого штампа, сгруппированные парно и напоминающие оттиски рамчатого штампа. Орнаментированы горшки по шейке и плечикам. На сосудах сочетается различная техника орнаментации: помимо традиционного рамчатого штампа появляются и оттиски гребенчатого штампа, которые, однако, применяются в меньшей мере. Отмечаются и оттиски гребенчатого штампа с широкой амплитудой шага (рис. 6: 26). Присутствуют ямочные вдавления, составленные в поясок, расположенный в нижней части шейки, на месте перехода в плечико, или на плечиках. Ямки как с округлым, так и с плоским дном, средней глубины. У одного сосуда ямки образуют небольшие выпуклины с обратной стороны (рис. 6: 25). Один гибридный горшок орнаментирован вторым рядом из ямок, нанесенным на плечики. Промежутки между ямками больше, чем у ямок первого ряда, при этом ямки располагаются между зигзагами (рис. 6: 22). В трех случаях ямки нанесены на горизонтальную линию из оттисков гребенчатого штампа в нижней части шейки (рис. 6: 22, 26, 27). Орнаментальные композиции включают зигзаги (одно, двух и трехрядные), выполненные оттисками рамчатого или гребенчатого штампа, наклонные оттиски рамчатого штампа и горизонтальные линии, нанесённые гребенчатым штампом. На одном горшке с обломанным краем, вероятно, нанесены крестики рамчатого штампа (рис. 6: 22). Орнаментированы сосуды, как правило, горизонтальными зигзагами, расположенными сразу под венчиком, середина же шейки, так же как и у классических сосудов с рамчатым декором, в основном остается свободной от орнамента, или орнаментальные мотивы редки.

Мотивы орнамента, выполненные оттисками гребенчатого штампа, представлены горизонтальными линиями (рис. 6: 22, 24, 26-27), у двух горшков из них составлен зигзаг (рис. 
6: 23, 25). На одном горшке под венчиком нанесена горизонтальная линия из оттисков овального рамчатого штампа, в нижней части шейки на месте перехода в плечико - горизонтальная линия гребенчатого штампа, ниже по плечикам - двухрядный зигзаг, а замыкают композицию не часто поставленные небольшие округлые вдавления (рис. 6: 24). К этой же гибридной группе керамики можно отнести и одну стенку с гребенчатым и рамчатым орнаментом. Из относительно коротких овальных оттисков гребенчатого штампа выполнена горизонтальная линия, рамчатым штампом (овальной и прямоугольной формы) сделан горизонтальный зигзаг, расположенный под линией из оттисков гребенки, и короткий вертикально-наклонный зигзаг (змейка) или лесенка с квадратами (рис. 5: 14). Наиболее важное место в орнаментации гибридной керамики занимают именно оттиски рамчатого штампа.

Далее перейдем к постановке вопросов и коснемся некоторых проблем, связанных с изучением керамики с рамчатым декором.

Интерпретация культурно-хронологической позиции материалов представляет определенные трудности, комплекс такой целостности фиксируется в Поветлужье и на сопредельных территориях впервые. На первый взгляд, техника исполнения орнамента на керамике Одоевского городища указывает на волосовские древности. Керамика, орнаментированная рамчатым штампом, известна на поселениях волосовского круга. Встречается она на памятниках развитого и позднего этапа развития средневолжского варианта волосовской культурно-исторической общности в Марийском Поволжье, таких как Мазарское 1, Барские Кужеры III, Сутырское IIa, Уржумкинское (Никитин, 2017, с. 98, 159; рис. 198-199; 233; 247; 385). Близкие по конфигурации оттиски овального рамчатого штампа имеются на керамике из Уржумкинского поселения (памятник позднего этапа волосовской КИО) (Никитин, 2017, рис. 385: 1). Керамика с рамчатым штампом фиксируется и на многослойных поселениях Костромского Поволжья с типологически выделяемыми комплексами волосовской культурно-исторической области (Борань, Станок 1, Федоровское) (Гурина, 1963, рис. 2, 21: 4; Гаврилова, 1980, рис. 1: 1-2, 2: 11; Новиков, 2011, рис. 9: 2). В ВолгоОкском междуречье керамика с коротким и длинным рамчатым штампом овально-вытянутой, листовидной форм также известна на волосовских поселениях - Володары, Сахтыш
II, Стрелка I, Вашутино (Цветкова, 1948, рис. 3: 4, 8; Крайнов, 1987, рис. 1: 7-8, 11; Гадзяцкая, Уткин, 1989, рис. 6-7 и др.). Такую технику исполнения орнаментов можно видеть и на волосовской керамике из поселений Языково 1 и Маслово болото 4 (поздневолосовская): рамчатый штамп - короткий и средний, овальный (Сидоров, 2002, рис. 1, 2). Рамчатый штамп (овально-вытянутой формы) известен и на волосовской керамике из поселения Имерка 1Б (Ставицкий, Королев, 2008, рис. 116: 5). В то же время следует учесть, что в отличие от керамики «одоевского типа» посуда на памятниках волосовского круга толстостенная, до 1,5 см, края чаще утолщены или отогнуты наружу.

Общий облик и морфологические данные посуды «одоевского типа» в целом кардинально отличаются от керамики волосовского облика, она имеет совершенно другую форму венчиков, толщину стенок, построение и принципы орнаментальных композиций. Между волосовской посудой и керамикой с рамчатым декором «типа одоевского» отсутствуют сколько-нибудь значимые общие признаки, позволяющие синхронизировать керамику и выявить генетическую связь. Надо принимать во внимание и отсутствие на Одоевском городище каменного набора, характерного для волосовской культурно-исторической области.

На поселении Лебяжий Бор 6 отпечатки рамчатого штампа появляются на керамике смешанного типа с волосовскими и имеркскими признаками (Челяпов, Иванов, 2009, рис. 6: 2-5), но керамика здесь толстостенная $(0,9$ 1,5 cм). Посуда хорошо заглажена, обладает прямым или слабопрофилированным венчиком, край имеет округлое или приплощенное завершение (Челяпов, Иванов, 2009, с. 250). Оттиски рамчатого штампа достаточно длинные, такие не характерны для керамики «одоевского типа», не схожи и орнаментальные мотивы.

Близкие по технике исполнения штампы встречаются на посуде иванобугорской (примокшанской) культуры, в частности из поселения Васильевский Кордон и местонахождения Желдаковка (Смольянинов, Скоробогатов и др., 2013, с. 286, рис. 2: 10; 6: 1). Тем не менее морфологические, технологические параметры и построение орнаментальной композиции совершенно другие. Орнамент, выполненный оттисками рамчатого штампа, покрывает всю поверхность иванобугорского горшка от края до дна. На поселении Мыс 
Доброй Надежды примокшанской культуры эпохи бронзы в Среднем Поочье также наблюдается керамика с схожими оттисками (Челяпов, 2002, рис. 3: 3): из отпечатков рамчатого штампа составлены горизонтальные ряды, при этом между отпечатками оставлены довольно большие промежутки, а сами оттиски короткие, некоторые из них по форме подквадратные - такие имеются на трех фрагментах керамики из Одоевского городища (рис. 5: 19; 6: 7,13$)$. В то же время, в отличие от посуды «одоевского типа», керамика примокшанской культуры имеет совершенно другой морфологический облик и стиль орнаментации.

Таким образом, керамика III - первой половины II тыс. до н. э. не может являться прототипом посуды с рамчатым декором из Одоевского городища, и попытки их отождествить оказались несостоятельными.

Выделяя косвенные признаки, которые могут свидетельствовать о хронологической позиции керамики «одоевского типа», подчеркнем, что на Одоевском городище отсутствуют фатьяновская, балановская, абашевская, фатьяноидная, чирковская, луговская, атабаевская и поздняковская посуда, а также сетчатая керамика эпохи бронзы. Облик культур бронзового времени на сопредельных к Поветлужью территориях хорошо представлен в литературе.

«Ребристым штампом» листовидной формы (Ставицкий, 2008, с. 197), практически идентичным по технике исполнения с отпечатками рамчатого штампа, орнаментирован один горшок аким-сергеевского облика из Шокшинского поселения: наклонные оттиски располагаются в один горизонтальный ряд по шейке сосуда (Ставицкий, 2008, рис. 287: 1). В то же время другие признаки аким-сергеевской посуды (Ставицкий, 2008, с. 196-199) не позволяют говорить о ее сходстве с керамикой «одоевского типа» и синхронизировать их, лишь общее морфологическое сходство верхней части посуды позволяет проводить сравнения с керамикой первого морфологического вида «типа одоевского». Отметим, что для керамики аким-сергеевского типа характерен орнамент, выполненный ямками (вдавления глубокие, образуют выпуклины с обратной стороны), «жемчужинами» и гребенчатыми или зубчатыми оттисками.

Оттиски рамчатого штампа овальной формы встречается на позднекаргопольской керамике в Карелии (Косменко, 1993, рис. 23, группа III, 5; Манюхин, 1996, рис. 56: группа III, 5) и появляются на керамике культуры лууконсаари. Датируется ранний этап культуры лууконсаари Прионежья второй половиной I тыс. до н. э. (Косменко, 1993, с. 170; 1996, с. 252). Начиная с середины I тыс. до н. э. датируют керамику типа лууконсаари И.С. Манюхин и А.М. Жульников (Манюхин, 2005 , с. 33 ; Жульников, 2005, с. 37). На керамике лууконсаари подобными оттисками, как правило, завершается орнаментальная композиция. Мотивы выполнены слабонаклонными оттисками рамчатого штампа, встречаются и оттиски с разным наклоном в одном горизонтальном ряду (Косменко, 1993, рис. 35: 10; 37). На одном горшке из группы I фиксируется горизонтальная елочка, составленная оттисками рамчатого штампа (Косменко, 1993, рис. 37). Конечно, стиль орнаментации керамики лууконсаари рамчатым штампом иной, отсутствуют мотивы, характерные для посуды из Одоевского городища, представленные зигзагами и горизонтальными линиями, часто сочетающимися и с ямками. Орнаментальные композиции, выполненные рамчатым штампом на керамике из Одоевского городища, сложнее. Близость орнаментальных сюжетов может определяться только наклонными оттисками рамчатого штампа, составленными в горизонтальный ряд, подобные мотивы присутствуют на керамике из Одоевского городища, хоть и в небольших количествах. Оттиски рамчатого штампа на керамике лууконсаари не составляют самостоятельных сложных композиций и являются дополнительными деталями орнамента, в частности бахрома из оттисков рамчатого штампа сочетается с каннелюрами. Каннелюры на одном горшке нанесены в нижней части шейки, а оттиски рамчатого штампа - по плечикам. Оттиски разбиты на группы, которые наклонены сначала в одну, потом в другую сторону, создавая видимость широкого зигзага (Косменко, 1993, рис. 35: 10). Близкое исполнение орнамента наблюдается на одном горшке из Одоевского городища, где вместо каннелюр линии по нижней части шейки нанесены оттисками рамчатого штампа, а завершают композицию оттиски рамчатого штампа, выстроенные в однорядный зигзаг на плечиках (рис. 3: 14). Однако технология изготовления керамики разная. Керамика лууконсаари изготавливалась с примесью асбеста, слюды, органики (небольшой процент) и песка в формовочной массе (Косменко, 1993, с. 151; Косменко, 1996, с. 241, 245), ранняя керамика в Прионежье содержит в формовочной массе примесь именно песка (Косменко, 1996, с. 


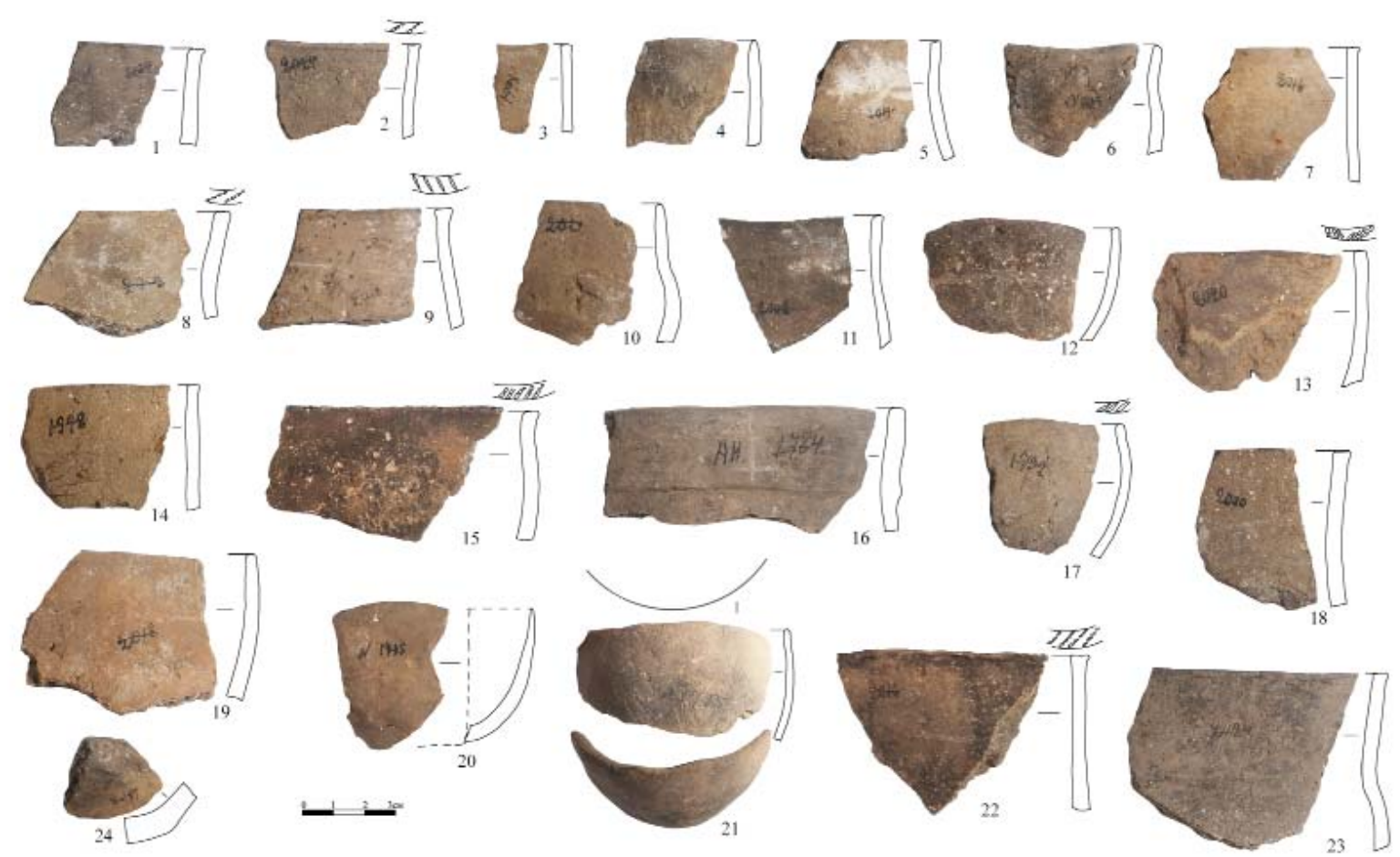

Рис. 7. Керамика вятско-ветлужской культуры АКИО

Fig. 7. Ceramics of the Vyatka-Vetluga culture of the Ananyino Cultural and Historical Region

241). Помимо круглодонной широко распространяется и плоскодонная посуда, при этом донные части зачастую орнаментируются (Косменко, 1993, с. 153; 1996, с. 245). В ЮгоЗападном Прибеломорье помимо вышеперечисленных примесей в формовочную массу добавляется и дресва, керамика из поселения Бохта II в основном плоскодонная (Жульников, 2005, с. 36). Таким образом, технологические и в большей степени морфологические параметры отличают керамику из Одоевского поселения и керамику лууконсаари. Отдаленное морфологическое сходство наблюдается между керамикой «одоевского типа» и частью керамики лууконсаари восточного типа с округлым дном (Косменко, 1993, рис. 35: 2, $11,13)$.

Важно выделить, что керамику лууконсаари, в т. ч. украшенную оттисками рамчатого штампа, М.Г. Косменко определял в группу посуды с орнаментами восточного типа (Косменко, 1993, рис. 35; 1996, с. 246). А.М. Жульников говорит о типологическом отличии керамики лууконсаари и ананьинской, обнаруживая между ними больше различий, чем сходства (Жульников, 2005, с. 36, 39). Вполне вероятно, что носители традиций рамчатой керамики, зафиксированной на Одоевском городище, могли оказать влияние на формирование керамических традиций в РЖВ (культура лууконсаари) на северо-западе, в Карелии в частности. Но пока это толь- ко предположение, которое требует дополнительной аргументации и выявления новых памятников с подобной посудой. Хронологический разрыв между данными культурными группами существует.

К югу от Онежского озера, в Белозерье, керамика, орнаментированная рамчатым штампом, встречается и на памятниках эпохи раннего Средневековья. Например, на поселении Крутик (IX-X вв.) небольшой процент посуды $(1,1 \%)$ украшен рамчатым штампом (Макаров, 1991, с. 145, рис. 7: 3). Элементы орнамента в виде рамчатого штампа Н.A. Макаров характеризует как чисто белозерские, отмечает, что за пределами Белозерья они исключительно редки (Макаров, 1991, c. 149). Как видим, традиция орнаментации посуды рамчатым штампом на Северо-Западе сохраняется достаточно долго, вплоть до рубежа I и II тыс. н. э.

Сейчас на памятниках РЖВ Поветлужья и сопредельных территорий неизвестна подобная керамика с рамчатым декором, как на Одоевском городище. Надо отметить, что для детализации хронологической позиции этого типа керамики не хватает стратифицированных данных, безусловно, нужны новые полевые исследования, прежде всего на самом Одоевском городище. Территория распространения этой керамики не выяснена.

Орнаментальные композиции на керамике из Одоевского городища больше напоминают 


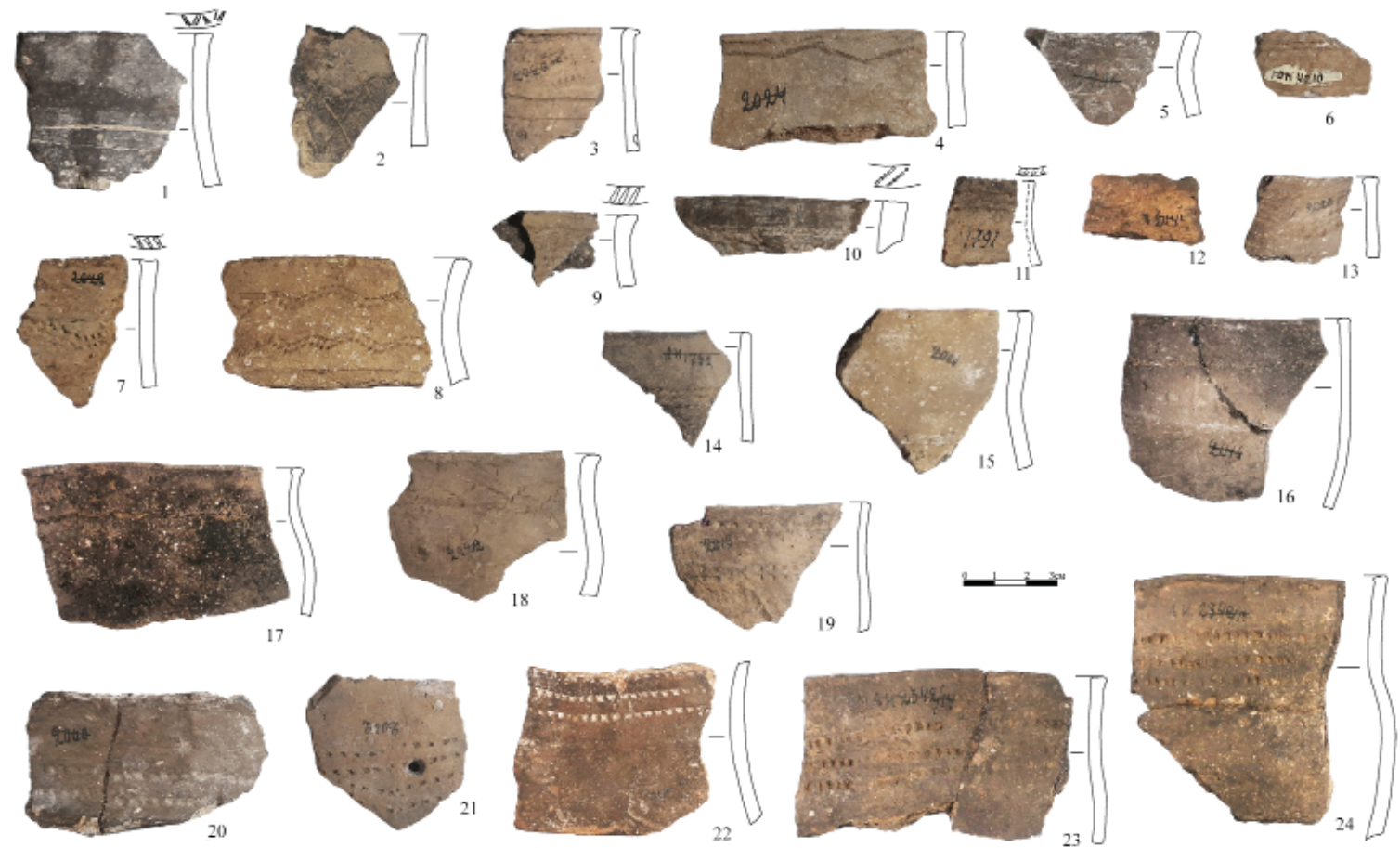

Рис. 8. Керамика вятско-ветлужской культуры АКИО $(1,3,5-24)$ и маклашеевского облика $(2,4)$

Fig. 8. Ceramics of the Vyatka-Vetluga culture of the Ananyino Cultural and Historical Region (1,3,5-24) and Maklasheevka appearance $(2,4)$

лебяжские орнаментальные традиции (зигзаги, горизонтальные линии, наклонные отрезки). Некоторые близкие морфологические и стилистические детали усматриваются и с позднекаргопольской керамикой. Конечно, все эти особенности намечают какие-то хронологические параллели, возможно, и связи, но не указывают на культурное единство и не перечеркивают оригинальности керамического комплекса с рамчатым декором «типа одоевского».

По отдельным морфологическим деталям: толщине стенок, орнаментальным мотивам, составу примесей в формовочной массе - такая посуда сближается с ананьинской керамикой, найденной на Одоевском городище, орнаментированной гребенчатыми или гребенчато-шнуровыми оттисками. В состав формовочной массы обоих типов керамики добавлена примесь измельченной раковины моллюсков, которая была предварительно термически обработана, а именно - нагрета на углях (прил. 1).

В этой связи возникает важный вопрос о соотношении керамики с рамчатым штампом с ананьинской и лебяжской посудой. Учитывая, что в небольшом количестве на памятнике появляется гибридная керамика с рамчато-гребенчатой орнаментацией, можно предполагать установление связей между носителями керамики «типа одоевского» и группами лебяжского населения, которые осваивали берега Ветлуги в самом начале РЖВ. Повторимся, что лебяжская керамика, хоть и в небольших количествах, в этом регионе известна на Богородском городище и в приустьевой части Ветлуги на Ардинском городище (Стоянов, 1959; Марков, 2007, рис. 29). Для хронологических привязок важна гибридная керамика. Признаком адаптации, судя по всему, небольших групп лебяжского населения в Поветлужье может являться гибридная посуда, обнаруженная на Одоевском городище. Гибридизация керамики с рамчатым декором выражена в сочетании на одном сосуде разной техники орнаментации, имеющей различное происхождение. Если гребенчатые оттиски генетически связаны с лебяжской керамикой, то рамчатые отпечатки выражают локальное своеобразие керамики «одоевского типа». Последние явно доминируют при украшении посуды. Прослеживается и схожий стиль лебяжской орнаментации нижней части шейки, в частности расположение ямок на оттисках гребенчатого штампа. Но, судя по небольшому количеству гибридной керамики, превалированию орнаментальной традиции рамчатым штампом, сохранению морфологических и технологических характеристик посуды, лебяжское население не оказало значительного воздействия на культурные традиции населения, изготавливавшего рамчатую керамику, что может быть связано в том числе и с малочисленностью 


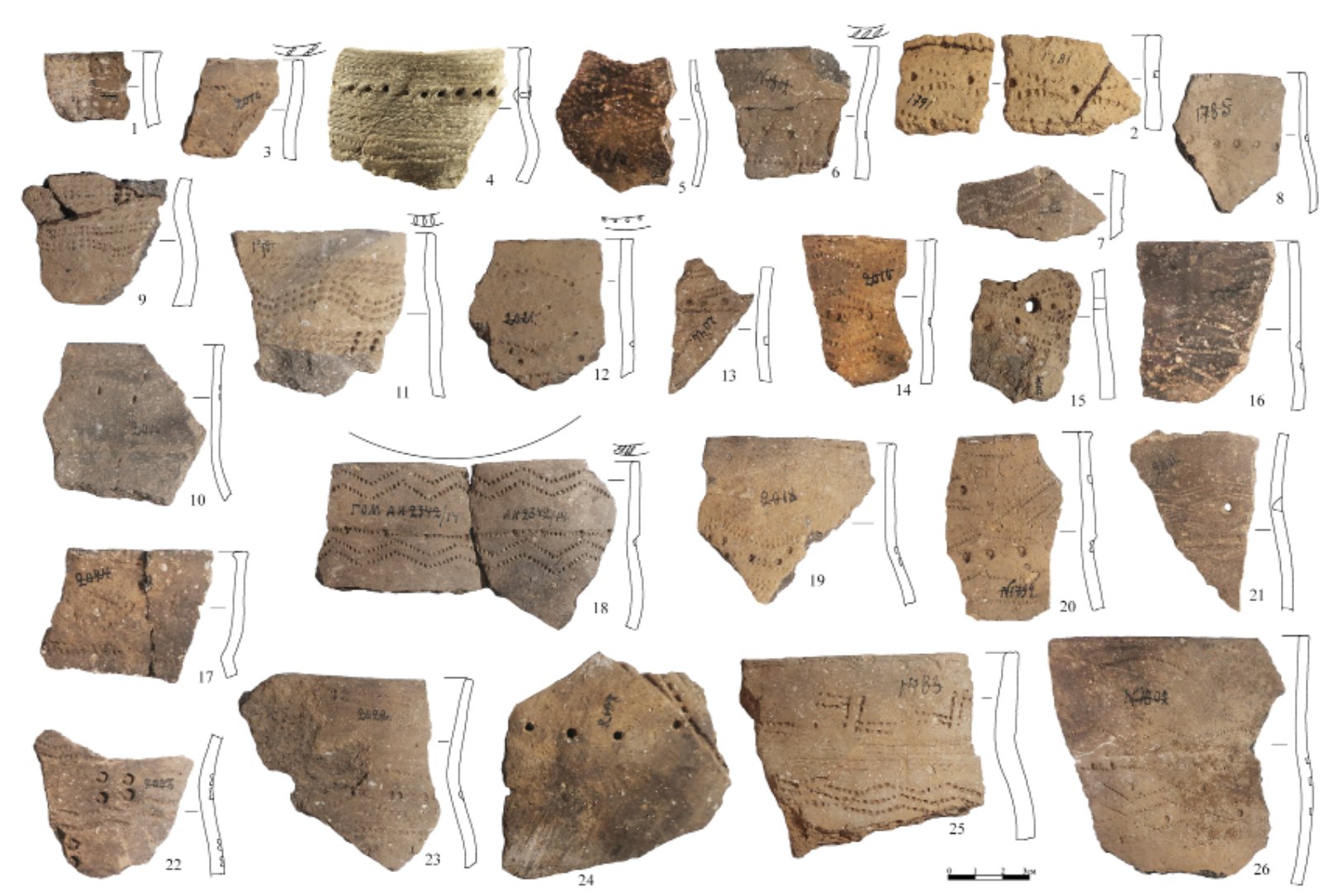

Рис .9. Керамика вятско-ветлужской культуры АКИО

Fig. 9. Ceramics of the Vyatka-Vetluga culture of the Ananyino Cultural and Historical Region

групп носителей лебяжских традиций, осваивавших берега Ветлуги.

Вполне допустимо, что комплекс керамики с рамчатым декором из Одоевского городища синхронен находкам из слоя 1 Богородского городища, который В.Е. Стоянов датировал предананьинским временем, от рубежа I тыс. до н. э. до VIII в. до н. э., где встречается и сетчатая керамика с отогнутым краем, орнаментированная по шейке глубокими ямками, и посуда маклашеевского облика, орнаментированная по шейке нарезной техникой (Стоянов, 1959, с. 181, 185, 189, табл. LV).

Данных для датировок комплекса керамики «одоевского типа» сейчас немного. Предметов-хроноиндикаторов нет. Тем не менее, учитывая вышеописанные обстоятельства, следует предположить, что керамика с рамчатой орнаментацией может являться одной из ранних на городище и занимать промежуточное положение между известными на окружающих территориях культурами эпохи поздней бронзы и ананьинской. Формирование и развитие такой керамики, наиболее вероятно, относится к финальной бронзе - началу РЖВ (XI/X-VIII/первая половина VII вв. до н. э.). Пока могут быть предложены только такие широкие временные рамки, будем надеяться, что в скором времени их удастся уточнить.
Верхние хронологические границы распространения керамики подобного типа могут ограничиваться VIII/первой половиной VII в. до н. э., временем до начала ананьинского заселения площадки Одоевского городища. Возможно говорить и о совместном, вероятно, недолгом, бытовании комплексов посуды «одоевского типа» и вятско-ветлужской культуры АКИО в середине VII вв. до н. э., на что могут указывать их нахождение в одних слоях на городище и сближающие признаки - некоторая стилистика орнаментации, примеси в формовочной массе (раковина), толщина стенок, морфология сосудов верхней части, округлодонность. В пользу этого, вероятно, свидетельствуют и один фрагмент ананьинского горшка, орнаментированного по краю оттисками рамчатого штампа листовидной формы (рис. 13: 12), и близко расположенные друг к другу отпечатки гребенчатого штампа, напоминающие рамчатые отпечатки, фиксирующиеся по краю другого ананьинского горшка (рис. 12: 25), подобные имеются и на стенках ананьинских сосудов (рис. 9: 10, 19, 20). Выделим и сосуды с высоким воротничком: воротничок такого типа встречается и на керамике ананьинской, и орнаментированной рамчатым штампом. В то же время важно отметить, что 


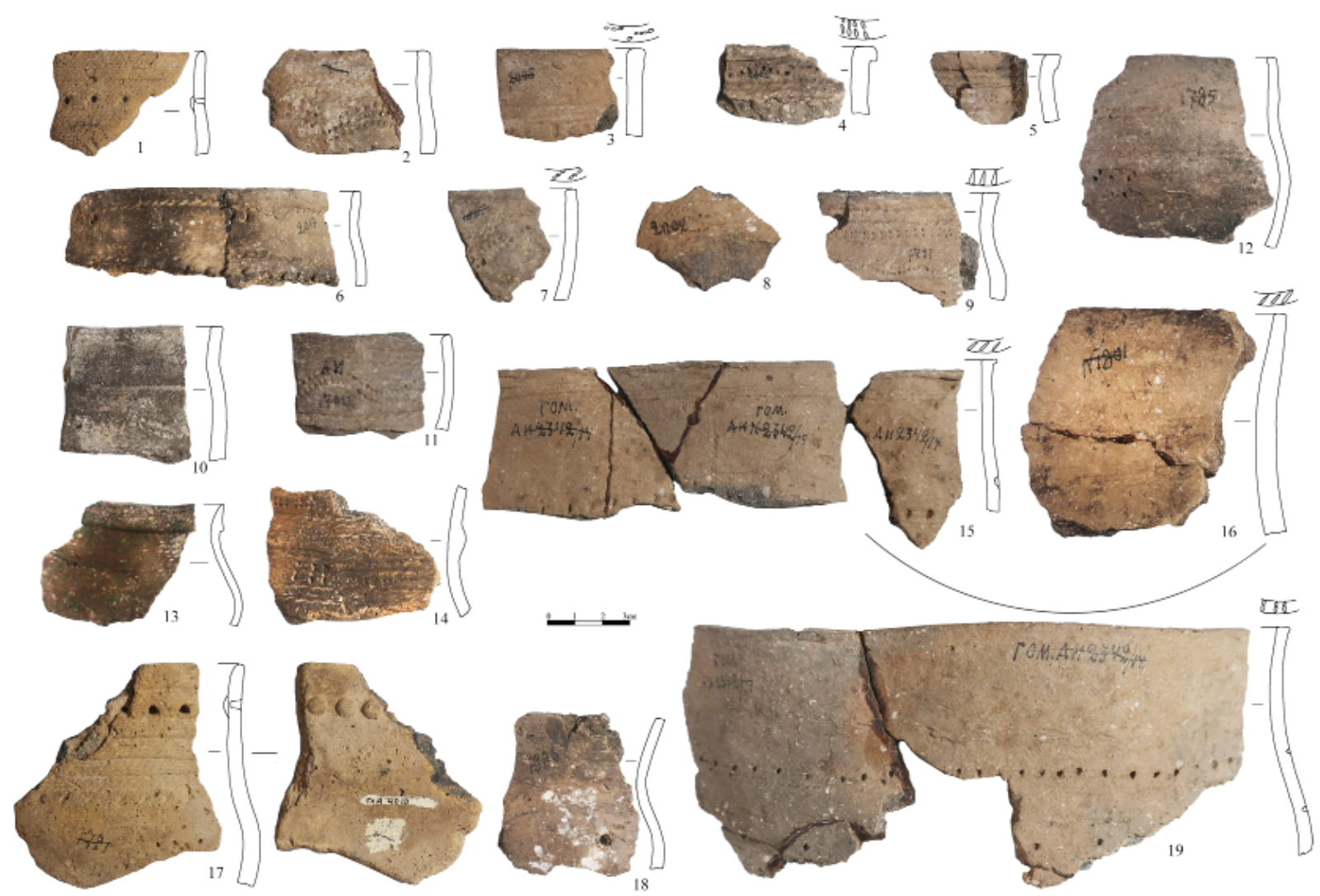

Рис. 10. Керамика вятско-ветлужской культуры АКИО

Fig. 10. Ceramics of the Vyatka-Vetluga culture of the Ananyino Cultural and Historical Region

нивелировки культурных традиций не произошло.

Начиная с VII в. до н. э. высокая поселенческая активность населения ВВК АКИО в Поветлужье, вероятно, вынуждает носителей рамчатых орнаментальных традиций покинуть привычные места обитания. Отголоски традиции орнаментации керамики рамчатым штампом фиксируются в середине I тыс. до н. э. на северо-западе (лууконсаари).

Нижние хронологические границы могут быть подчёркнуты наличием на памятнике немногочисленной посуды маклашеевского времени с нарезным орнаментом, которым выполняется, в частности, косая решетка по шейке (рис. 8: 2). Такая керамика, имеющаяся на памятнике в небольшом количестве, поддерживает хронологическую позицию данных комплексов.

Сосуды именно первой морфологической группы с плавновогнутой шейкой и выпуклыми или слабовыпуклыми плечиками, очевидно, могут считаться наиболее ранними. Такая форма сосудов близка керамике атабаевского этапа маклашеевской культуры и аким-сергеевского типа, в какой-то степени и лебяжской посуде. Отсутствует и керамика подобного вида, орнаментированная рамчатым штампом и гребенчатыми оттисками. В коллекции керамики с рамчатым декором из Одоевского городища доминируют сосуды второй группы. Гибридная керамика также целиком представлена сосудами только этого вида и, видимо, существует совместно с посудой 2 типа в начале РЖВ.

В пользу более раннего освоения площадки городища, предшествующего ананьинскому заселению, указывает отсутствие шамота в примесях керамики с рамчатым декором, шамот появляется в формовочной массе уже раннеананьинской посуды с глазчатыми ямками. Интересен и тот факт, что керамика с глазчатыми ямками содержит шамот с добавками в него раковины (прил. 1). Вполне допустимо, что для формирования формовочной массы ананьинской посуды, обнаруженной на Одоевском городище, использовалась именно керамика с рамчатым декором, содержащая примеси раковины моллюсков.

Это только первая интерпретация, и, очевидно, в будущем появятся уточнения по хронологии данных материалов. Повторимся, что четко стратифицированных комплексов нет, находятся они в одних слоях с ананьинской посудой. Керамика с рамчатым декором «одоевского типа» неизвестна на других памятниках ананьинского круга, но имеет общие морфологические корни (но не более) 


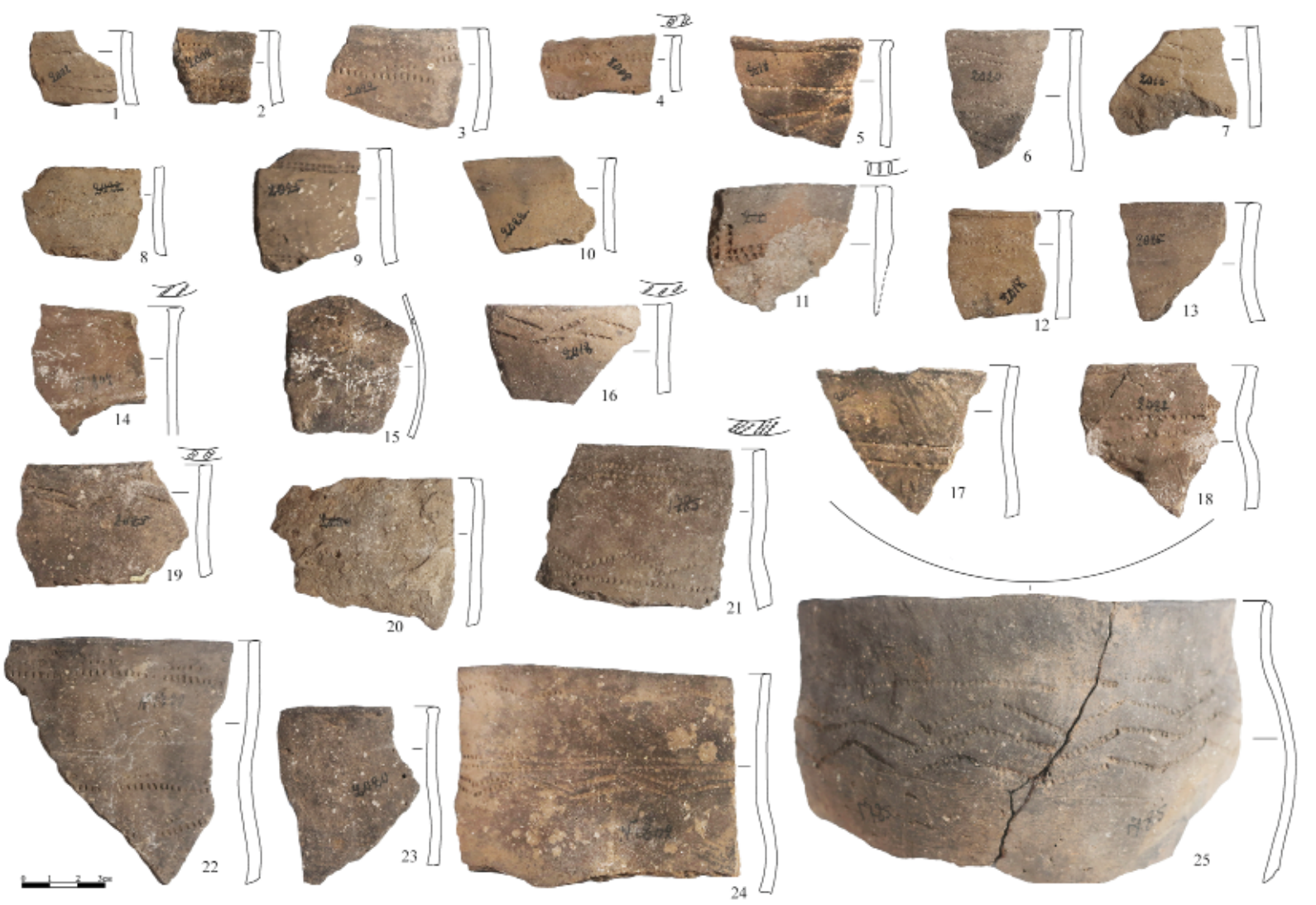

Рис. 11. Керамика вятско-ветлужской культуры АКИО

Fig. 11. Ceramics of the Vyatka-Vetluga culture of the Ananyino Cultural and Historical Region

с керамикой маклашеевской и постмаклашевской культур: посуда второго типа - с высоким и средним по величине подцилиндрическим горлом и выпуклыми или слабовыпуклыми плечиками. На высокой шейке появляется и слабовыраженный воротничок, такой же имеется на керамике вятско-ветлужской культуры АКИО. Керамика с рамчатым штампом отличается от характерной посуды текстильного мира: примесь в тесте - раковина моллюсков, поверхность заглажена, иные техника и стиль орнаментации. В то же время имеются близкие морфологические данные, выраженные в слабой профилировке верхней части горшка, такой профиль характерен для сетчатой керамики финала поздней бронзы и начала РЖВ. Стоит обратить внимание на один фрагмент стенки, найденной на участке Д в нижнем слое (рис. 6: 21). Его, вероятно, стоит отнести к посуде с рамчатым декором. Керамика заглажена снаружи, на внутренней поверхности имеются следы четкой выраженной горизонтальной штриховки. Подобным образом обрабатывается внутренняя поверхность части сетчатой керамики эпохи поздней бронзы и переходного к раннему железному веку этапа на поселениях Костромского Поволжья - Федоровское, Говядиново, Вознесенское 1. Вышеприведенные косвенные признаки также могут указывать на эпоху, когда формируется керамика с рамчатым штампом.

В завершение обзора еще раз обратим внимание на особенности керамики с рамчатым декором. Орнамент выполнен в основном оттисками рамчатого штампа, которые практически не сочетаются с элементами, сделанными в другой технике, только вдавления дополняют орнаментальную композицию. Ямки, как правило, неглубокие, часто с плоским или кольцеобразным дном, делаются и вдавления с коническим или округлым профилем. Редко ямки глубокие и образуют выпуклины с обратной стороны. Располагаются вдавления в центре крестиков и ромбов, на горизонтальных линиях, выполненных из оттисков рамчатого штампа, или составляют отдельный поясок по шейке. Иногда поясок из ямок выделяет воротничок.

Некоторые орнаментальные мотивы (крестики, лапки водоплавающих, зигзаги, горизонтальные линии, поясок из ямок по шейке) близки раннеананьинской посуде, присутствуют пересекающиеся сюжеты. Например, птичьими лапками орнаментируется керамика из поселения Курган и Аргыжского городища, только мотивы выполнены гребенчатыми оттисками (Марков, 2007, табл. 


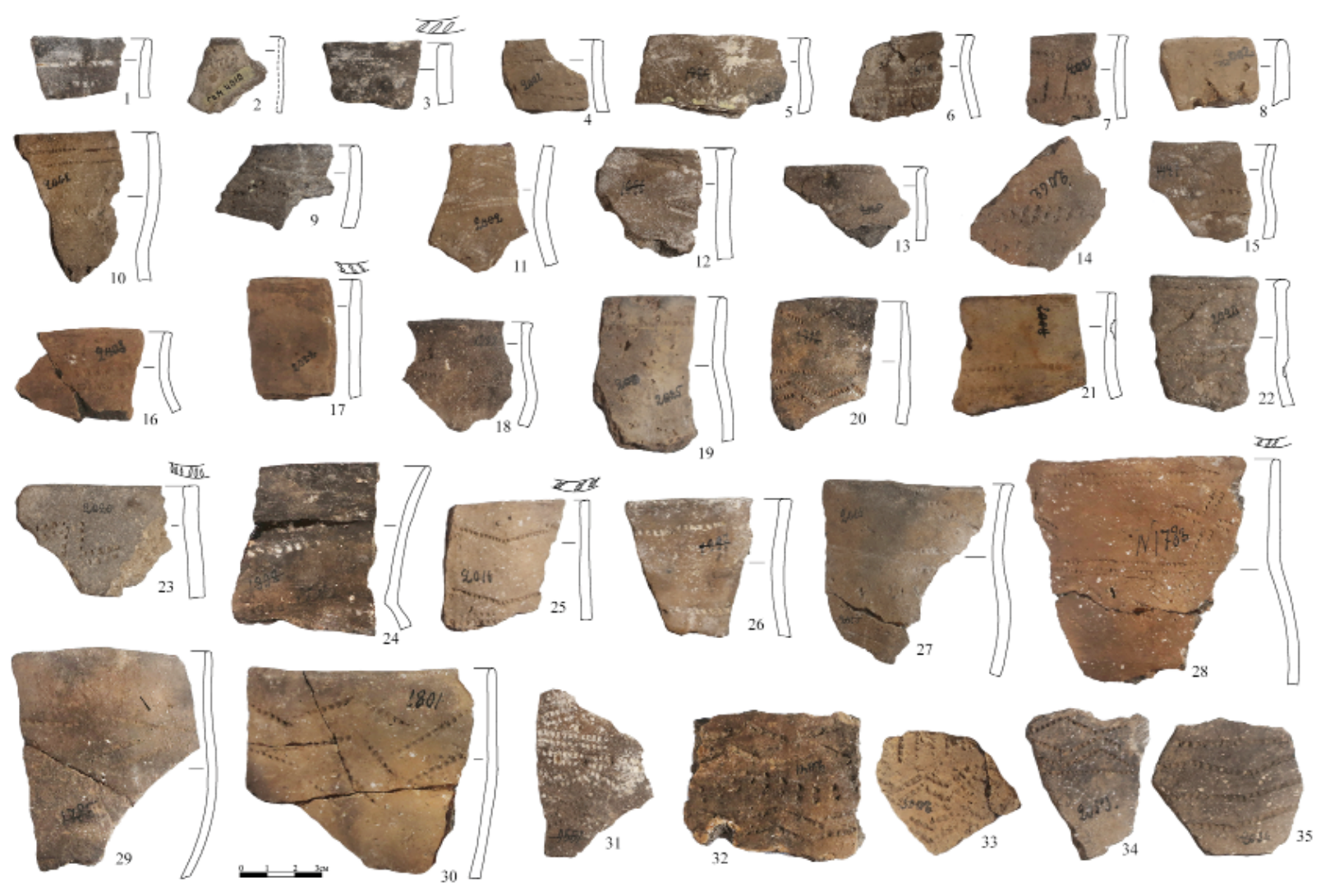

Рис. 12. Керамика вятско-ветлужской культуры АКИО

Fig. 12. Ceramics of the Vyatka-Vetluga culture of the Ananyino Cultural and Historical Region

10). Сочетание крестиков, расположенных в горизонтальный ряд, и горизонтальных линий, сделанных гребенчатыми оттисками, поверх одной из которых делаются ямки, отмечено на посуде из городищ ананьинского времени Сухой Берсут и Белоглазовское (Марков, 1988, рис. 1: 6; 2007, рис. 22: 1, 4; 26: 8). Сюжетная линия из крестиков, выполненных гребенчатыми оттисками, известна и на керамике из раннего слоя Маклашевского 2 городища (Марков, 1988, рис. 3: 2, 6), датированного РЖВ (Чижевский, Хисяметдинова, 2020, c. 204), и на Богородском городище (Стоянов, 1959, табл. LVI: 6). Крестики, выполненные гребенчатыми оттисками и пробитые ямкой по центру перекрестия, известны на городище Ройский Шихан (Архипов, 1962, табл. XLI). Сочетается данный мотив орнамента с глазчатыми ямками. Расположение крестиков в начале орнаментальной композиции сближает их с сюжетами, выполненными на керамике с рамчатым штампом из Одоевского городища. Сюжеты с крестиками собственно из оттисков гребенчатого штампа, расположенных на шейке сосуда, известны и на ананьинской посуде из Одоевского городища, где так же по центру крестика ставится ямочное вдавление (рис. 12: 22). Каким образом происходило заимствование орнаментальных традиций, пока остается не совсем ясным, возможно, они имели и самостоятельное развитие у разных групп населения.

На гибридной керамике появляется горизонтальный ряд из гребенчатых оттисков, поверх которых сделаны ямки. Сочетание при орнаментации посуды горизонтальных линий из оттисков гребенчатого штампа с ямками, расположенными по шейке, вполне типично для лебяжской орнаментальной традиции (Буров, 1983, рис. 3; Стоколос, 1997, рис. 32; Марков, 2007, рис. 23: 1, 24: 4; рис. 29: 3-4). Подобные стилистические сюжеты весьма присущи и орнаментальной традиции вятсковетлужской культуры (гребенчато-шнуровой керамики) АКИО, когда ямки наносятся на горизонтальные линии из оттисков гребенчатого штампа или шнура, что можно наблюдать на городищах Ройский Шихан и Аргыжском (Архипов, 1962, табл. XLI; Митряков, Черных, 2014, рис. 18) и поселениях Средней Волги и Поветлужья (Стоянов, 1959, табл. LVII; Халиков, 1962, табл. XVII; Архипов, Патрушев, 1982, рис. 5; Ефремова, Соловьев, 2014, рис. 12). Такие сюжеты встречаются и на ананьинских памятниках Нижнего Прикамья (Марков, 2007, рис. 22: 4).

Изменения, произошедшие при орнаментации посуды «одоевского типа», можно связы- 


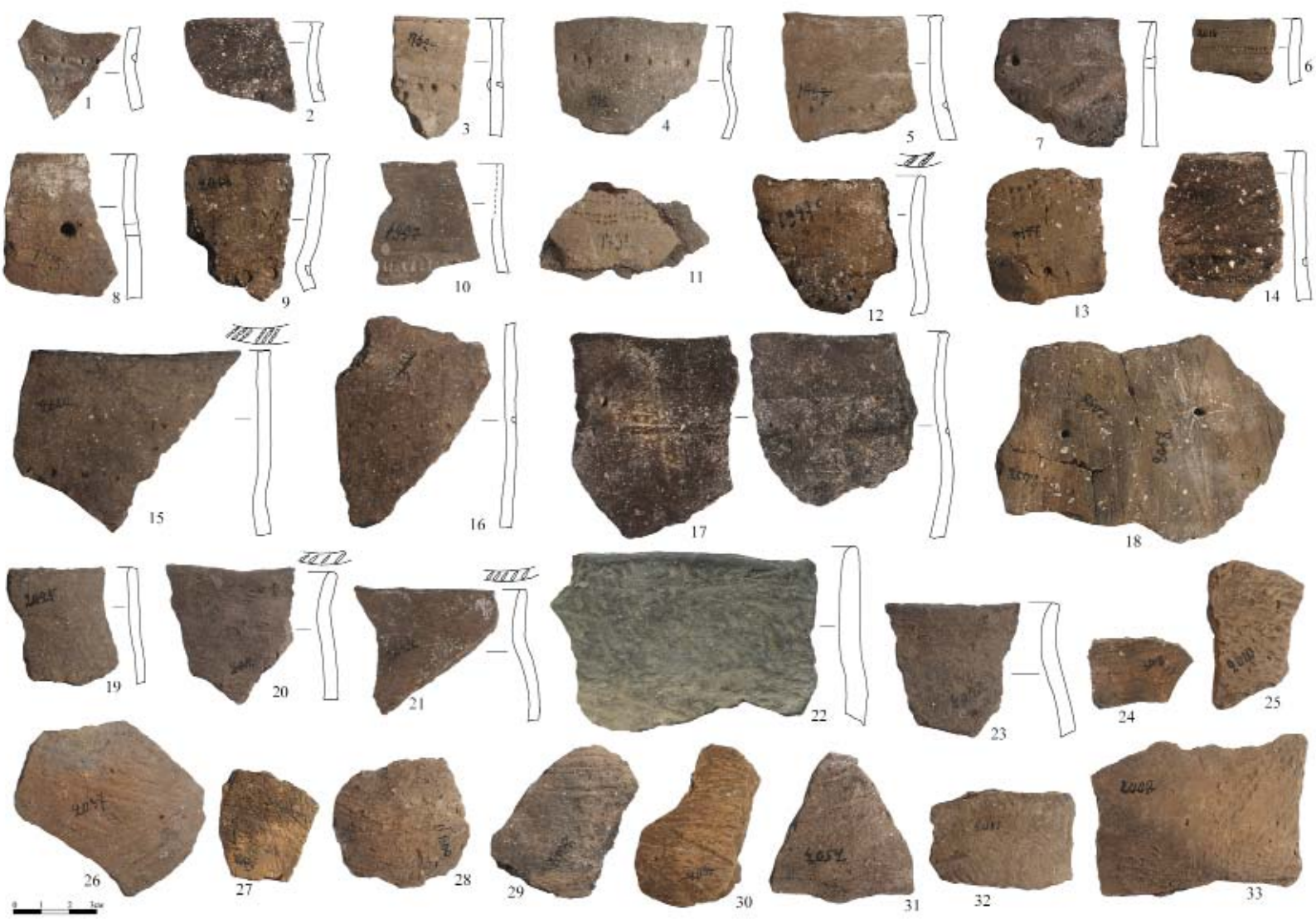

Рис. 13. Керамика вятско-ветлужской культуры АКИО (1-18) и сетчатая керамика (19-33).

Fig. 13. Ceramics of the Vyatka-Vetluga culture of the Ananyino Cultural and Historical Region (1-18) and reticulate ceramics (19-33).

вать с распространением лебяжских древностей на Ветлуге, а появление горизонтальных линий из оттисков гребенчатого штампа, в т. ч. в сочетании с ямкой, и расположенных по шейке на посуде второго морфологического типа, могут прямо указывать на лебяжскую орнаментальную традицию. На посуде первого вида таких мотивов не наблюдается, для нее наиболее присущи зигзаг из оттисков рамчатого штампа и мелкие ямки с коническим профилем или с сужающимися к округлому дну стенками. Для посуды второго вида наиболее характерны ямки с кольцеобразным и плоским дном, хотя сохраняется и орнаментация ямками с коническим профилем и с сужающимися к округлому дну стенками. Для лебяжской керамики характерны глубокие ямки с округлым или плоским дном. Вся гибридная керамика сочетает орнаментальные традиции носителей посуды с рамчатым штампом и лебяжской - слабопрофилированные формы, с высокой шейкой и слабовыпуклыми плечиками, основные мотивы орнамента представлены оттисками рамчатого штампа, меньшая роль при их выполнении отводится гребенчатым оттискам.

Таким образом, выделим основные черты керамики «одоевского типа»:
А) сосуды, изготовленные с примесью раковины в формовочной массе;

Б) преобладание слабопрофилированных форм горшков с плоским краем, высокой подцилиндрической или слабоотогнутой шейкой и слабовыпуклыми плечиками, распространена и посуда с воротничком;

В) орнаментация верхней части горшка (шейка и плечики), на шейке, в средней ее части, часто между орнаментами остается свободное пространство;

Г) исполнение орнамента рамчатым штампом;

Д) орнамент практически всегда начинается от края, расположение горизонтальное;

Е) среди мотивов преобладают горизонтальные линии и зигзаги. Ряды из ямок, как правило, наносятся в нижней части шейки, на месте перехода в плечико, в т. ч. поверх горизонтальных линий. Появляется второй ряд ямок, обязательно с увеличенным интервалом между вдавлениями;

Ж) для гибридной керамики характерен орнамент, нанесенный оттисками рамчатого и гребенчатого штампа. Гребенчатым штампом выполняются горизонтальные линии и зигзаг.

Обозначенные признаки являются определяющими для керамики данного типа. 
Итак, представленный выше керамический комплекс с реликтовым рамчатым штампом выражает несомненное единство оставившего его населения, показывает устойчивость орнаментальных традиций и очень важен для оценки культурной обстановки в Поветлужье в финале бронзового времени и начале РЖВ, предшествующем ананьинскому расселению. Посуда подобного облика на других памятниках, расположенных в Поветлужье, пока неизвестна; возможно, следует заново пересмотреть материалы старых раскопок. Население Одоевского городища, изготовлявшее керамику с рамчатым декором, сохраняет традиции подобной орнаментации культур эпохи раннего металла (в первую очередь волосовской). По всей вероятности, должны иметься и памятники с рамчатой керамикой, заполняющие хронологические пробелы как между волосовскими древностями и керамикой «одоевского типа», так и между последней и лууконсаари. Появление носителей рамчатой керамики на берегах р. Ветлуги и их судьба пока остаются загадкой. Ещё раз отметим, что керамика с рамчатым декором находилась в одних слоях (2-3) с ананьинской посудой вятско-ветлужской культуры АКИО.

2. Группа посуды вятско-ветлужской культуры (гребенчато-шнуровой керамики) ананьинской культурно-исторической области (ВВК АКИО)

Комплекс керамики ананьинского времени вычленяется по особенностям стратиграфии (основное скопление - в нижних слоях 2 и 3) и типологии керамических сосудов. Ряд фрагментов найден в верхнем слое 1, переотложены. По небольшим фрагментам верхней части насчитывается 170 сосудов этой группы (рис. 7-13). В их числе выделены и фрагменты от 4 сосудов, которые, вероятно, относятся к маклашеевскому времени. Фрагменты стенок как минимум четырех горшков можно причислить к лебяжской керамике. Керамика сильно измельчена, редко встречаются крупные обломки. Поверхность большинства фрагментов заглажена, встречаются со слегка подштрихованной поверхностью. Фрагмент стенки от сосуда с подштрихованной поверхностью, отобранный для технологического анализа, находится в группе II, посуда которой изготовлялась с примесями шамота и раковины моллюсков (прил. 1). Посуда относительно тонкостенна. Толщина стенок посуды варьирует от 0,3 до 0,65 см. Отметим, что в коллекции много именно тонкостенной посуды $(0,4-0,45$ см), как и на Богородском горо- дище (Стоянов, 1959, с. 183). Цвет керамики от светло-коричневого, коричневого до серого, темно-серого. В изломе - от коричневых, серо-коричневых оттенков до темно-серого, черного цвета, встречаются двух- и трехслойные фрагменты. С внутренней стороны посуда заглажена. Горшки округлодонные. Встречаются округло-уплощенные формы дна (рис. 7: 24).

По морфологическим признакам выделяется посуда с сужающимся горлом (I); с вертикальными или слабоотогнутыми горловинами (II); со среднеотогнутыми и сильноотогнутыми горловинами (III); непрофилированная, баночно-чашевидной формы (IV). Шейка может быть низкая (a), средняя (б) или высокая (в). Плечики слабовыпуклые (1), выпуклые (2) и округлые в виде сглаженного ребра (3).

В выборку включены только фрагменты, имеющие достаточные данные для определения морфологии верхней части посуды, а именно шейки сосудов, переход шейки к плечикам и сами плечики. Таких фрагментов меньше, чем выделенных сосудов вообще, их количество составляет 119.

Посуда II типа в коллекции явно превалирует, её показатели равны $69,7 \%$. В меньшей степени представлены сосуды III (16\%) и IV типов (12,6\%). Сосудов I типа со средней по величине шейкой и слабовыпуклыми или выпуклыми плечиками менее всего $(1,7 \%)$.

Среди сосудов второго типа преобладают горшки с относительно высокой шейкой и слабовыпуклыми плечиками $(54,4 \%)$, в гораздо меньшем количестве встречаются сосуды с низкой шейкой и слабовыпуклыми плечиками $(15,6 \%)$ и с высокой шейкой и выпуклыми плечиками (12\%). Небольшой процент приходится на сосуды с средней шейкой и слабовыпуклыми (6\%) и выпуклыми плечиками (6\%). Единичны горшки с низкой шейкой и выпуклыми плечиками $(3,6 \%)$ и средней по величине шейкой и сильновыпуклыми плечиками в виде сглаженного ребра (2,4\%).

Керамика третьего типа в большинстве представлена горшками с выпуклыми плечиками (11 экз.) и средней или высокой шейкой, реже встречается низкая шейка. Меньше в этой группе сосудов со слабовыпуклыми плечиками (6 экз.). Зафиксировано два горшка с сильновыпуклыми плечиками в виде сглаженного ребра.

Отдельно подсчитаны и шейки, обломанные в основании (низкая, средняя, высокая). Фрагментов низких шеек выделено 11, сред- 
них 5 и высоких 26. Итого 42 шт. Как правило, шейки обладают прямым профилем. Остальные 9 горшков имеют обломанный край венчика.

Итак, отметим, что в коллекции преобладают цилиндрошейные сосуды, но имеются и горшковидные с плавно отогнутым горлом, и посуда чашевидных форм. На такую особенность ананьинской керамики Поветлужья указывал еще А.Х. Халиков (1977, с. 243). Сосуды с высокой прямой шейкой М.В. Воеводским были выделены в наиболее древнюю керамическую группу, которая характерна для третьего слоя Одоевского и второго слоя Богородского и Русенихинского городищ (Воеводский, 1951, с. 159). Горшки с вертикальными горловинами, как на Одоевском городище, вполне типичны для Богородского и Русенихинского городищ (Стоянов, 1959; Халиков, 1977). По морфологическим показателям керамика из Одоевского городища сближается и с нижнекамской посудой, для которой типичны именно сосуды второго типа, их доля на памятниках составляет 58,4\% (Марков, 2007, табл. 1, табл. 22). Для посуды из нижнекамских поселений В.Н. Марковым была выделена важная особенность, выраженная в наличии в ранних комплексах керамики с высокими прямыми шейками и раздутым туловом, с течением времени происходит понижение высоты шейки и увеличение ее отогнутости, плечики становятся менее выпуклые (Марков, 2007, с. 29-31). На Одоевском городище превалирует посуда со слабовыпуклыми плечиками.

На Вятке преобладает посуда со слабовыпуклыми плечиками и низкими, иногда сильно отогнутыми, горловинами. Характерны и рельефные элементы в виде воротничка или валика (Марков, 2007, с. 47). На данную морфологическую особенность керамики бассейна р. Вятки, выделенную В.Н. Марковым, указывают и А.Е. Митряков с Е.M. Черных, характеризуя керамику Грехневского поселения, Скорняковского и Аргыжского городищ (Митряков, Черных, 2014, с. 174-180). Высокий процент посуды со слабовыпуклыми плечиками из Одоевского городища по этому показателю сближает ее с керамикой именно вятских памятников. На таких городищах, как Ройский Шихан, Белоглазовское и Аргыжское, доля посуды II и III типов находится практически в равных количествах (Марков, 2007, табл. 27), в то же время доля сосудов I типа так же мала, как и на Одоевском городище. Заметно выше на Одоевском городище доля посуды баночно-чашевидной формы, в отличие от вятских памятников, где наибольший процент таких горшков обнаружен на Аргыжском городище (4,6\%) (Марков, 2007, табл. 27).

Вятская ананьинская керамика обладает своеобразием, которое выражается в исключительном богатстве ее орнаментации и преобладании гребенчатых и шнуровых оттисков при ее исполнении, дополняемых и ямками (Збруева, 1952, с. 71; Марков, 2007, с. 47). Определяя эти особенности, В.Н. Марков указывал на значительное сходство вятской и ветлужской гребенчато-шнуровой керамики и большое ее отличие от керамики нижнекамских поселений. В свою очередь, ветлужская керамика, по мнению В.Н. Маркова, имеет некоторые сходные черты и с керамикой западноволжской (Марков, 2007, с. 47-49), с чем нельзя не согласится. В частности, В.С. Патрушев, рассматривая ананьинскую керамику из памятников Марийского Поволжья, вслед за А.Х. Халиковым (Халиков, 1977, с. 230; Патрушев, 2017б, с. 114) отметил преобладание форм сосудов со слабопрофилированным прямым или прикрытым горлом, доля которых составляет $63 \%$ на Малахайском поселении и 76,4\% на Копаньском городище, указывая при этом, что превалирует такая посуда и на Ветлуге, например, в 3 слое Богородского городища. Такая же керамика весьма характерна и для Одоевского городища.

Посуда с высокой и средней по величине прямой или слегка отогнутой шейкой, характерная для памятников вятско-ветлужской культуры АКИО Поветлужья, встречается на памятниках бассейна р. Вятки, хоть и в меньшем количестве. Например, на Кривоборском городище выделяются сосуды с высокой прямой или слабо отогнутой шейкой (Оруджов, 2017a, с. 90-91), сосуды с прямыми венчиками и хорошо выраженными плечиками имеются на городище Ройский Шихан (Архипов, 1962, с. 201), цилиндрошейные горшки встречаются на Мальковском городище, их доля составляет 27\% (Халиков, 1977 , c. 235).

В целом можно отметить и некоторую наметившуюся близость между типами посуды из Одоевского городища и вятскими памятниками, такими как Ройский Шихан, Белоглазовское и Аргыжское городища (Марков, 1988, табл. 1; 2007, табл. 27), на которых посуда второго типа составляет ощутимые доли в коллекциях. Однако стоит обратить внимание и на отличающие детали. Так, для памят- 
ников из бассейна р. Вятки наиболее характерна низкая и средняя по величине шейка, в отличие от посуды Одоевского городища с высокой и средней по величине шейкой. Доля посуды с высокой шейкой на вятских городищах крайне мала, составляет в среднем около 4\% (Марков, 2007, табл. 27). Имеются различия в соотношении посуды II и III типов на памятниках. Более высокий процент посуды третьего типа наблюдается на вятских городищах. Сосуды с низкой отогнутой шейкой для Одоевского городища мало характерны.

Основная традиция формирования отогнутого низкого края на вятской керамике, очевидно, складывалась под влиянием носителей лебяжских керамических традиций и определялась близостью вятских памятников к основной территории распространения лебяжских древностей в отличие от ветлужских. Для лебяжской керамики характерен короткий венчик, часто и отогнутый (Стоколос, 1997, с. 257, рис. 32; Буров, 1983, рис. 2-3). Такая традиция формирования края типична и для классической шнуровой керамики (Ашихмина, 2014). На памятниках ВВК АКИО Поветлужья, напротив, фиксируется увеличение доли цилиндрошейных сосудов с высокой и средней по величине шейкой, близких волжским памятникам АКИО (Халиков, 1962, табл. XVIII, XXVIII-XXIX; 1977, рис. 85-86; Ефремова, Соловьев, 2014, рис. 12-13; Патрушев, 2017б, рис. 9-12) и занимающих значительное место в комплексах керамики ПМК АКИО. Данные обстоятельства подчеркивают и определяют особенности формирования региональных керамических комплексов в рамках ВВК АКИО, обусловленные в первую очередь территориальным положением памятников.

У трех сосудов из Одоевского городища фиксируется ребро, расположенное с внутренней стороны, на месте перехода высокой шейки в плечико. У одного горшка шейка практически прямая, слабоотогнутая, у двух других - отогнутая наружу (рис. 9: 17; 12: 24; 13: 9). Такая керамика занимает значительное место среди посуды самого раннего зуевоключевского комплекса, а также характерна для маклашеевской керамики (Ашихмина, 2014 , с. 71 , рис. 40, 42; Марков, 2007, рис. 38-42), только в отличие от посуды ЗуевоКлючевского I городища керамика из Одоевского городища орнаментирована достаточно просто. Два фрагмента украшены исключительно оттисками гребенчатого штампа, не составляющими сложные композиции, а один, на месте перехода шейки в плечико, - ямочными вдавлениями. Керамика с ребристым выступом внутри встречается в постмаклашеевских (поселение Курган, Черепашье, Казанский кремль) (Марков, 2007) и акозинских комплексах (Маклашеевское II и Казанка II городища) (Кузьминых, Чижевский, 2009, рис. 10: $1,5,11)$.

Далее отметим, что на Одоевском городище некоторое своеобразие проявляется на керамике со слабовыраженным воротничком на цилиндрошейных сосудах с высокой горловиной и слабовыпуклыми плечиками. По воротничку сосудов наносится орнамент из оттисков гребенчатого штампа, иногда в сочетании с ямками (рис. 9: 14, 20; 12: 22). Такое рельефное выступление снизу подчеркивается пояском из ямок с плоским или кольцеобразным дном. Подобные высокие воротнички характерны и для посуды с рамчатым штампом «одоевского типа». На вятской керамике воротничок выделен более отчетливо, как и на другой части посуды с таким декором из Одоевского городища, при этом шейка у таких горшков чаще плавно вогнутая, край отгибается наружу, плечики более выпуклые.

Небольшое количество посуды с воротничком представлено и на Богородском, и на Русенихинском городищах (Стоянов, 1959, табл. LVIII: 1, 4; LXII: 1; LXIII: 3, 5). Воротничок так же довольно высокий и выполнен на высокой прямой или слабоотогнутой шейке, как и на сосудах из Одоевского городища. В бассейне р. Вятки близкая посуда известна на Кривоборском городище, где воротничок сделан на сосуде с высокой отогнутой шейкой (Оруджов, 2017a, с. 90, рис. 3). Единственное различие - это степень выпуклости плечиков: на Кривоборском городище они более выпуклые в отличие от посуды Поветлужья.

Оформление края посуды ВВК АКИО из Одоевского городища достаточно вариативно. Большинство сосудов - с плоским краем, что составляет $46 \%$. Встречаются и плоские венчики с Т-образными небольшими наплывами $(11 \%)$ и Г-образными наплывами наружу (6\%). Округлый край фиксируется у $27 \%$ сосудов. Остальная доля приходится на посуду с краем, скошенным внутрь (2\%), округлоприостренным (2\%), округло-утолщенным с валиковым наплывом (4\%), слегка скошенным наружу (1\%) или гофрированным (1\%).

Плоский венчик типичен для посуды из городищ Вятского бассейна - Ройский Шихан, Белоглазовское, Аргыжское (Марков, 2007, 
табл. 28). Характерен он и для керамики из городищ Сухой Берсут и Черепашье (Марков, 2007, табл. 23). Можно отметить, что плоский край свойственен посуде ананьинского мира в целом. Вторая по встречаемости - это посуда с округлым краем (Марков, 2007, Ашихмина, 2014; Халиков, 1962, с. 143). Посуда с Т- и Г-образными краями известна на Малахайском поселении и Ардинском городище (Патрушев, 2017б, с. 113; Архипов, Патрушев, 1982 , с. 54), имеется и на поселениях Нижней Камы (Марков, 2007, табл. 4). В небольших количествах на памятниках встречаются и округло-приостренный или острый скошенный край, а также другие формы (Ашихмина, 2014, табл. V-11; Марков, 2007, табл. 4, 23, 33).

Орнаментированы по краю венчика 40 горшков, что составляет $23 \%$ от всей ананьинской посуды. Орнамент представлен косыми оттисками гребенчатого штампа, косыми или вертикальными нарезками, мелкими округлыми ямками, клиновидными вдавлениями, оттисками двузубого гребенчатого штампа, оттисками гребенчатого штампа, нанесенного горизонтально по окружности венчика, оттисками наклонного овального гребенчатого штампа. На одном горшке нанесены оттиски листовидного рамчатого штампа. Из оттисков гребенчатого штампа, сгруппированных по три, образуются и зигзаги, зигзаг сформирован и из спаренных нарезок. Также зафиксированы и косопоставленные оттиски гребенчатого штампа, сгруппированные по три. Наиболее часто орнаментируется плоский край. Орнаментация края посуды оттисками косопоставленного гребенчатого штампа характерна для керамики лебяжской культуры (Буров, 1983, рис. 2, 3), весьма типичен орнамент по краю и для ананьинской керамики Нижнего Прикамья (Марков, 2007, табл. 4) и вятских памятников, таких как городище Ройский Шихан, Белоглазовское, Аргыжское (Марков, 2007, табл. 28). Не часто, но орнаментируется и край ананьинской посуды Марийского Поволжья (Патрушев, 2017б, рис. 9, 11, 12).

Керамика с воротничком представлена небольшим количеством сосудов (рис. 7: 16; 9: 14, 18, 20; 10: 13-14; 11: 18; 12: 22), выделяется и керамика со слабовыраженным высоким воротничком (рис. 9: 14, 20; 12: 22). Всего в коллекции насчитывается 9 фрагментов от сосудов, декорированных воротничком, при этом большинство из них (5) орнаментированы гребенчатыми оттисками, один сосуд неорнаментированный. У 4 сосудов, орна- ментированных гребенчатыми оттисками, под воротничком нанесены ямки, орнамент из оттисков гребенки при этом выполнен по шейке и плечикам (крестики, зигзаги, наклонные отрезки). Один сосуд украшен в нижней части шейки горизонтальными линиями из оттисков гребенчатого штампа. Выделяется горшок, орнаментированный полосками из шнуровых оттисков (сгруппированы по 2 и 4 ряда) и двузубой гребенкой. У двух сосудов по линии, выполненной гребенчатым штампом и расположенной под воротничком, нанесены ямочные вдавления. Один горшок орнаментирован под коротким воротничком шестью плотно составленными горизонтальными рядами из шнуровых оттисков.

Керамика позднеананьинского облика с воротничком на Одоевском городище представлена только одним сосудом (рис. 7: 16). Аналогичная посуда широко распространена на памятниках в бассейне р. Вятки, в частности, на Чижевском, Кривоборском и Скорняковском городищах (Чижевский и др, 2016, Оруджов, 2017а, Оруджов, Глушков, 2019). Начало позднего периода АКИО А.А. Чижевским определено рубежом V/IV вв. до н. э., завершение - III/II вв. до н. э. (Чижевский, 2017).

Обратим внимание на географию распространения посуды с воротничком, прослеживается весьма интересная тенденция уменьшения доли посуды с воротничком на памятниках вятско-ветлужской культуры (гребенчато-шнуровой керамики) АКИО с востока - северо-востока на запад - югозапад. Для посуды из поселений бассейна p. Вятки воротнички являются важным элементом декора, в Поветлужье на известных сейчас памятниках они встречаются реже. На поселениях Волжского бассейна и в приустьевой части р. Ветлуги такая посуда не распространена, о её отсутствии в Волжском бассейне говорит и В.С. Патрушев (Патрушев, 2017б, с. 115). Невыразительные воротнички очень редко встречаются на нижнекамской посуде (Марков, 2007, с. 47).

Керамика с валиковыми выступами, так же как и воротничковая посуда, малочисленна на Одоевском городище. В коллекции встречено всего четыре сосуда с таким оформлением края (рис. 10: 4-5), три из них орнаментированы по краю. Три сосуда из этой серии украшены шнуровыми оттисками под валиковым выступом по шейке, на одном в сочетании с мелкими ямками, еще на одном - с оттисками двузубого гребенчатого штампа. Ямки образу- 
ют волну или зигзаг. Близкая позднеананьинская керамика найдена на Кривоборском городище (Оруджов, 2017а, рис. 7: 9; 9, 2). Имеется один неорнаментированный по шейке сосуд. Керамика с двузубым и трехзубым штампом т. н. концегорского типа датируется IV-III/II вв. до н. э. (Чижевский, 2016, с. 50, Чижевский, 2019 , с. 135). На Богородском городище керамика с двузубым штампом найдена в верхнем слое (Стоянов, 1959, с. 187), что также подтверждает ее более поздний характер и распространение в позднеананьинское время. М.В. Воеводский отмечал, что «двойная гребенка» появляется только на посуде второй группы и выступает как новый элемент орнамента (Воеводский, 1951, с. 167). В коллекции Одоевского городища подобная керамика встречается в небольшом количестве, найдено 9 фрагментов. Чаще наносятся двузубые оттиски гребенчатого штампа: на одном горшке вертикально поставленные двузубые отпечатки нанесены на полосу из шнуровых оттисков (рис. 10: 14), на другом сочетаются с ромбами и зигзагами, выполненными гребенчатыми отпечатками (рис. 12: 32). Орнамент, сделанный из двузубого и трезубого гребенчатого штампа, сочетается с шнуровыми оттисками, ямками и мелкими вдавлениями.

В состав формовочной массы керамики ВВК АКИО добавлялась раковина моллюсков, раковина в сочетании с шамотом и реже - только шамот с органической добавкой. Для изготовления ананьинской посуды, как правило, употреблялась незапесоченная или слабозапесоченная ожелезненная глина (прил. 1). Характерна примесь измельченной раковины моллюсков, которая предварительно была нагрета на углях. Посуда АКИО с аналогичными примесями термически обработанной раковины известна на Ардинском городище (Михеев, 2017, с. 34). Примечательно, что примесь раковины, нагретой на углях, определяет специфику и керамики с рамчатым штампом «одоевского типа».

Доминирующая традиция изготовления керамики на Одоевском городище - это сосуды из незапесоченной ожелезнённой глины с примесью термически обработанной и измельченной раковины моллюсков (группа Ia). В этой группе находятся горшки с гребенчатым (в т. ч. с оттисками, выполненными с широким шагом) и гребенчато-шнуровым орнаментом, а также украшенные полосами из шнуровых оттисков (по 4 в ряд), сочетающихся с глубокими ямками. Совмещение в рецепте формовочной массы примеси шамота и раковины (группа II) свойственно для керамики, орнаментированной шнуровыми оттисками, с такими примесями встречается и посуда, украшенная гребенчатым штампом (в т. ч. фрагмент с мотивами в виде крестиков). Изменение состава примесей ананьинской посуды из Одоевского городища может связываться с распространением в Поветлужье акозинских древностей. Еще А.Х. Халиков, определяя особенности средневолжского варианта АКИО, указывал на наличие минеральных примесей (песка) в керамике с текстильной обработкой поверхности (Халиков, 1962, с. 115). Так, текстильная (акозинская) керамика из Ардинского городища в основном изготавливалась из глины с естественными примесями мелкого песка, без видимых искусственных примесей, но появляется и посуда, которая делалась по рецепту глина+шамот (Михеев, 2017, с. 35). На Одоевском городище, в отличие от Ардинского, отсутствует керамика этого времени, поверхность которой обработана сетчатыми отпечатками. Встречается сетчатая керамика финала бронзового времени - начала РЖВ на Богородском городище. На памятниках бассейна р. Вятки редко, но фиксируется керамика с шамотом (Чижевский и др., 2016, с. 34; Оруджов, 2017a, с. 90). Керамика с шамотом, появившаяся на Кривоборском городище в позднеананьинский период, по мнению Э.И. Оруджова, может являться свидетельством инокультурного влияния (Оруджов, 2017a, с. 92).

Технологические изменения, происходившие в процессе развития керамики ВВК АКИО, связанные с появление шамота, в том числе использованием многокомпонентных рецептов при изготовлении керамики (глина с шамотом и раковиной моллюсков, шамот с органическим раствором), могут говорить о смешанности культурных традиций. При этом изменения происходили на разных этапах формирования ВВК АКИО. Могут они связываться и с влиянием акозинской культуры АКИО, не исключено и воздействие носителей сетчатых керамических традиций, появление которых в третьей четверти I тыс. до н. э., в позднеаньинский период, отмечено на Одоевском городище. Для сетчатой керамики этого времени минеральные добавки (шамот) в формовочную массу также характерны. Минеральные примеси, только в виде толченой дресвы, вполне типичны и для лебяжской керамики (Стоколос, 1997, с. 257).

Ананьинская керамика с примесями шамота в Поветлужье имеет в т. ч. и ранний облик. 
Например, примесь шамота в составе формовочной массы зафиксирована у сосуда со сложным гребенчато-шнуровым орнаментом, включающим глазчатые ямки, из Одоевского городища (рис. 9: 4). Сосуд с глазчатыми ямками выделен в третью технологическую группу, отличающуюся от других видом искусственно введённых примесей. Сделаем интересное наблюдение: этот сосуд не содержит в формовочной массе примесь раковины в чистом виде, однако ее наличие фиксируется в шамоте, для изготовления которого, очевидно, были использованы более ранние сосуды с рамчатым штампом. Шамот с добавками раковины отмечается и у сосуда с простым орнаментом, включающим одиночные линии шнуровых оттисков и ряд скобчатых вдавлений (рис. 10: 6). Таким образом, раковина моллюсков так или иначе присутствовала в формовочной массе. Кроме шамота сосуд с глазчатыми ямками содержит и примесь органического раствора. Органические добавки присутствуют и в лебяжской керамике, например, на таких стоянках, как Ягкодж и Знаменка (Стоколос, 1997, с. 257). Важно и то, что располагаются эти поселения в самом южном ареале основного ядра лебяжской культуры (Стоколос, 1997, рис. 24; Буров, 1983, рис. 1).

\section{Орнаментаиия}

Техника орнаментации керамики ВВК АКИО Одоевского городища - гребенчатый штамп, шнуровые оттиски, вдавления и нарезки. На особенность вятско-ветлужской керамики, выраженную в сочетании посуды с гребенчато-шнуровой и гребенчатой орнаментацией, часто дополняемой и ямками, для которой типичен и многорядный шнур без разделителей, указывает А.А. Чижевский (Чижевский, Хисяметдинова, 2020, c. 228).

При разделении ананьинской керамики по технике орнаментации, встречаемости элементов орнамента на одном сосуде складывается следующая картина (показатели выражены в \%). Здесь же подсчитана и неорнаментированная керамика.

А. Керамика с гребенчатыми оттисками (в т. ч. с двузубым штампом). Ее доля в коллекции велика и достигает 42,55\%;

Б. Керамика с гребенчатыми оттисками (в т. ч. с двузубым штампом) и ямками также занимает значительную часть - $17 \%$;

В. Доля керамики с гребенчатыми отпечатками и шнуровыми оттисками незначительна $-3,2 \%$;
Г. Керамика со шнуровыми оттисками и ямками также встречается нечасто - 2,2\%;

Д. Доля керамики с ямками достигает $7,8 \%$;

Е. Керамика со шнуровыми оттисками $3,8 \%$

Ж. Керамика со шнуровыми оттисками, гребенчатыми отпечатками и ямками $-1,1 \%$;

3. Керамика с шнуровыми оттисками и мелкими вдавлениями $-4,8 \%$;

И. Керамика с мелкими вдавлениями $2,2 \%$

К. Керамика с мелкими вдавлениями, шнуровыми оттисками и гребенчатым штампом (в т. ч. с двузубым штампом) - 2,7\%;

Л. Керамика с шнуровыми оттисками и прочерченной линией $-0,55 \%$;

М. Керамика с гребенчатыми оттисками, мелкими вдавлениями и нарезным орнаментом $-0,55 \%$;

Н. Керамика с гребенчатыми оттисками, ямками и нарезным орнаментом - 0,55\%;

О. Неорнаментированная керамика $-11 \%$.

Достаточно высокий процент неорнаментированной керамики складывается, в частности, за счет сильной фрагментарности коллекции. Так, многие сосуды сколоты по шейке и могли орнаментироваться в нижней части шейки и по плечикам. Неорнаментированная посуда из Одоевского городища встречается только чашевидных форм и с прямой или слегка отогнутой шейкой, и выпуклыми или чаще слабовыпуклыми плечиками (рис. 7: 1-23). Морфологические особенности такой посуды из Одоевского городища с высокой и средней подцилиндрической шейкой и выпуклыми и слабовыпуклыми плечиками весьма близки именно постмаклашеевской традиции. Неорнаментированная посуда не характерна для нижнекамских памятников и поселений АКИО Марийского Поволжья, Сиухинского и Малахайского городища в частности (Марков, 2007, с. 26; Ефремова, Соловьев, 2014, с. 230; Патрушев, 2017б, с. 113). С другой стороны, неорнаментированная керамика может указывать на поздний период освоения площадки городища носителями вятско-ветлужской культуры АКИО (IV-III вв. до н. э.), аналогичная неорнаментированная керамика, в т. ч. с воротничком, имеется на вятских городищах (Скорняковское, Кривоборское, Чижевское) и датируется позднеананьинским временем (Чижевский и др., 2016; Оруджов, 2017a, Оруджов, Глушков 2019). На поздний характер заселения указывают и орнаментальные признаки ананьинской керамики Одоевского 
городища, такие как двузубая гребенка, сочетание разреженных рядов из оттисков шнура и мелких ямок. Подчеркнем, что керамика с простым шнуровым орнаментом содержит в примеси формовочной массы кроме раковины и шамот (прил. 1), аналогично примесям керамики из Скорняковского и Кривоборского городищ (Чижевский и др., 2016, с. 34; Оруджов, 2017a, с. 90, 92). Исключение составляют небольшие неорнаментированные сосудики чашевидной формы (рис. 7: 12, 20-21), распространение которых предполагается и в раннеананьинское время. Близкий сосуд известен на Богородском городище (Стоянов, 1959, табл. LV: 4).

Учитывая особенности формирования коллекции ананьинской керамики на Одоевском городище, ее стратиграфическую неразделенность, выделение позднеананьинской керамики возможно только типологически. Принимая во внимание стиль орнаментации, выраженный в однообразии мотивов, наличие керамики с валиковым выступом, неорнаментированной воротничковой посуды, сосудов, орнаментированных двузубым штампом и имеющих простые сюжеты орнамента, выполненного шнуровыми оттисками, можно предположить, что доля позднеананьинской керамики в коллекции составляет около 30\%, но не более, учитывая морфологию посуды. Большинство найденной керамики на памятнике относится к среднему периоду АКИО.

Нарезной или прочерченный орнамент отмечен всего на пяти сосудах и не характерен для ананьинской посуды Одоевского городища. Эти данные не противоречат замечанию, сделанному В.Н. Марковым, об очень редком применении прочерчено-резного орнамента в ананьинскую эпоху (Марков, 2007, с. 27), к таким же выводам ранее приходила А.В. Збруева (Збруева, 1952, с. 66). Раннеананьинская и позднеананьинская посуда с резным орнаментом встречается на Зуево-Ключевском I городище (Ашихмина, 2014, табл. V-15). Резная техника на сосудах из Одоевского городища сочетается с орнаментом, выполненным шнуровыми оттисками, гребенчатым штампом и ямками. Нарезной техникой выполнены горизонтальные линии, зигзаги или косая решетка (рис. 8: 1-4, 8). На одном горшке горизонтальная прочерченная линия нанесена в нижней части шейки, а по шейке сосуд орнаментирован двойной волной из гребенчатых оттисков, местами переходящих в мелкие округлые вдавления (рис. 8: 8). На трудности определения техники выполнения узоров мелкими вдавлениями и гребенчатым штампом указывал еще В.Н. Марков (2007, с. 27). Волна из оттисков гребенчатого штампа или мелких вдавлений весьма характерна для посуды из Одоевского городища (рис. 8: 7-8; 9: 9, 11; 10: 2, 4, 5, 9, 11; 13: 11, 13), волной из мелких вдавлений орнаментируется и керамика из Богородского городища (Стоянов, 1959, табл. LIX). Истоки украшения посуды изгибающимися линиями гребенчатого штампа восходят к лебяжской орнаментальной традиции, такой мотив встречается на посуде из поселения Знаменка (Буров, 1983, рис. $3: 2$ ).

На двух фрагментах керамики мотивы орнамента исполнены только резной техникой, они могут быть отнесены к предананьинскому времени (рис. 8: 2, 4). Один их них обломан на месте перехода шейки в плечики и был орнаментирован ямками, слабо фиксирующимися на месте слома. Это сосуды с прямой подцилиндрической шейкой, один с округло-приостренным, другой с плоским краем, орнаментированные по шейке косой решеткой и зигзагом соответственно. Так как фрагменты обломаны по нижней части шейки, степень выпуклости плечиков не определена. Посуда маклашеевского облика с подцилиндрической шейкой и выпуклыми плечиками с нарезным орнаментом по шейке имеется и на Богородском городище, найдена она в 1 слое и соотносится с ранними комплексами керамики, нарезной техникой создаются мотивы в виде ромбов и косой решетки (Стоянов, 1959 , с. 184, табл. LV: 5, 6).

Сюжет в виде косой решетки известен на маклашеевской керамике из поселения Курган и городища Черепашье (Марков, 2007, рис. 38: 1, 42: 5; Кузьминых, Чижевский, 2009, рис. 5: 5), Икской І стоянки (Ашихмина, 2014, рис. 35: 5). В частности, на поселении Курган имеется сосуд с приостренным краем - такой же, как и на Одоевском городище. В то же время характерен такой мотив орнамента для более раннего этапа маклашеевской культуры - атабаевского, где его доля значительна и достигает 14\%. Зигзаг из нарезок также типичен для керамики атабаевского этапа маклашеевской культуры (Лыганов, Морозов, Азаров, 2019, с. 55-56, табл. 2).

Наличие на горшках с нарезным орнаментом из Одоевского городища прямой подцилиндрической шейки, не характерной для керамики атабаевского этапа маклашеевской культуры, дает основания предполагать развитие этой посуды именно на маклашеев- 
ском этапе, который датируется XII/XI - X вв. до н. э. (Кузьминых, Чижевский, 2017, с. 24). Вероятно, посуда с резным орнаментом, обнаруженная на памятнике в небольшом количестве, может отражать какие-то локальные культурные контакты населения, изготовлявшего керамику с рамчатым декором, с носителями маклашевских традиций или, как уже отмечалось, указывать на время освоения площадки городища носителями керамики «одоевского типа». Выделяются общие, сближающие их, морфологические (эпохальные) признаки керамики, но не более. У керамики с рамчатым декором отсутствуют текстильная обработка поверхности и минеральные примеси в формовочной массе, отмечаются и разные орнаментальные сюжеты, и техника их исполнения.

В керамической коллекции из Одоевского городища встречено три сосуда с плоским краем и прямой шейкой, украшенных фигурками, возможно, напоминающими водоплавающих птичек (рис. 9: 25; 11: 11; 12: 23). Изображения выполнены в гребенчатой технике. На фрагментах от двух горшков фигурки сделаны зигзагообразными линиями сразу под краем венчика (рис. 11: 11; 12: 23). Фрагменты мелкие, малоинформативные и, вероятно, соотносятся с древностями маклашеевского времени. Близкие сюжеты в виде зигзагообразных линий известны на маклашеевской посуде городища Черепашье (Марков, 2007, рис. 41: 3; Кузьминых, Чижевский, 2009, рис. 5: 5).

Подобные изображения интерпретированы С.В. Ошибкиной и О.С. Гадзяцкой как фигурки водоплавающих птичек, в т. ч. выполненных зигзагообразными линиями. По их мнению, такие сюжеты характерны для керамики эпохи бронзы (Ошибкина, 1980; Гадзяцкая, 1992, с. 132-134). Такие сюжеты типичны и для более ранних эпох.

Выделяется в коллекции третий оригинальный сосуд с сюжетом, возможно, изображающим водоплавающих птиц, который имеет явное ананьинское происхождение и орнаментирован гребенчатым штампом и оттисками шнура. Фигурки, напоминающие птичек, развернуты друг от друга и плывут в разные стороны, под ними нанесены две полоски из спаренных шнуровых оттисков, заканчивается композиция трёхрядным зигзагом из отпечатков гребенчатого штампа (рис. 9: 25). Обозначенная композиция выражает локальное своеобразие ананьинских орнаментальных традиций Одоевского городища, на других памятниках ананьинского круга такой сюжет сейчас неизвестен. По составу примесей этот сосуд относится к группе I a (c жженой раковиной).

Посуда Одоевского городища имеет как сложные орнаментальные композиции, сочетающие комбинации из гребенчатых оттисков с ямками, гребенчато-шнуровые оттиски и ямки и оттиски шнура с ямками, так и достаточно простые, составленные из элементов, выполненных в одной технике, чаще всего гребенчатой.

Керамика ВВК АКИО из Одоевского городища орнаментировалась по шейке $(45,2 \%)$, одновременно по шейке и плечикам (46,6\%) или только по плечикам $(8,2 \%)$ - наблюдается небольшое доминирование посуды, орнаментированной по плечикам и шейке. По этим показателям керамика из Одоевского городища несколько схожа с посудой из Антоновского городища, в меньшей мере - из Маклашеевского II (Марков, 2007, табл. 5). Небольшой ряд сосудов из Одоевского городища по тулову имеет ямки и сквозные отверстия. Посуда вятских городищ, таких как Ройский Шихан, Белоглазовское и Аргыжское, в большей степени одновременно орнаментирована по шейке и плечикам (Марков, 2007, табл. 29). Здесь следует учесть и наличие позднеананьинской посуды на Одоевском городище, которая орнаментировалась меньше, а сосуды в основном украшались по шейке. Таким образом, процент посуды раннего (второй этап) и среднего периода из Одоевского городища, орнаментированной по шейке и плечикам одновременно, может быть сопоставим с обозначенными вятским памятниками.

На Одоевском городище преобладает керамика, орнаментированная только гребенчатыми оттисками или оттисками гребенчатого штампа в сочетании с ямками, мелкими вдавлениями и прочерченными линиями, она составляет 69\% от всей орнаментированной керамики. В чистом виде оттиски гребенчатого штампа встречены на 74 сосудах. Доля керамики, орнаментированной шнуровыми оттисками, в т. ч. в сочетании с гребенчатым штампом, ямками, прочерченными линиями и мелкими вдавлениями, достигает $21 \%$. Отдельно оттиски шнура наблюдаются лишь на 9 сосудах. Керамика, орнаментированная только ямками и мелкими вдавлениями, составляет $10 \%$. Имеется только один сосуд с глазчатыми ямками.

Ямочные вдавления на посуде из Одоевского городища встречаются различных видов, 

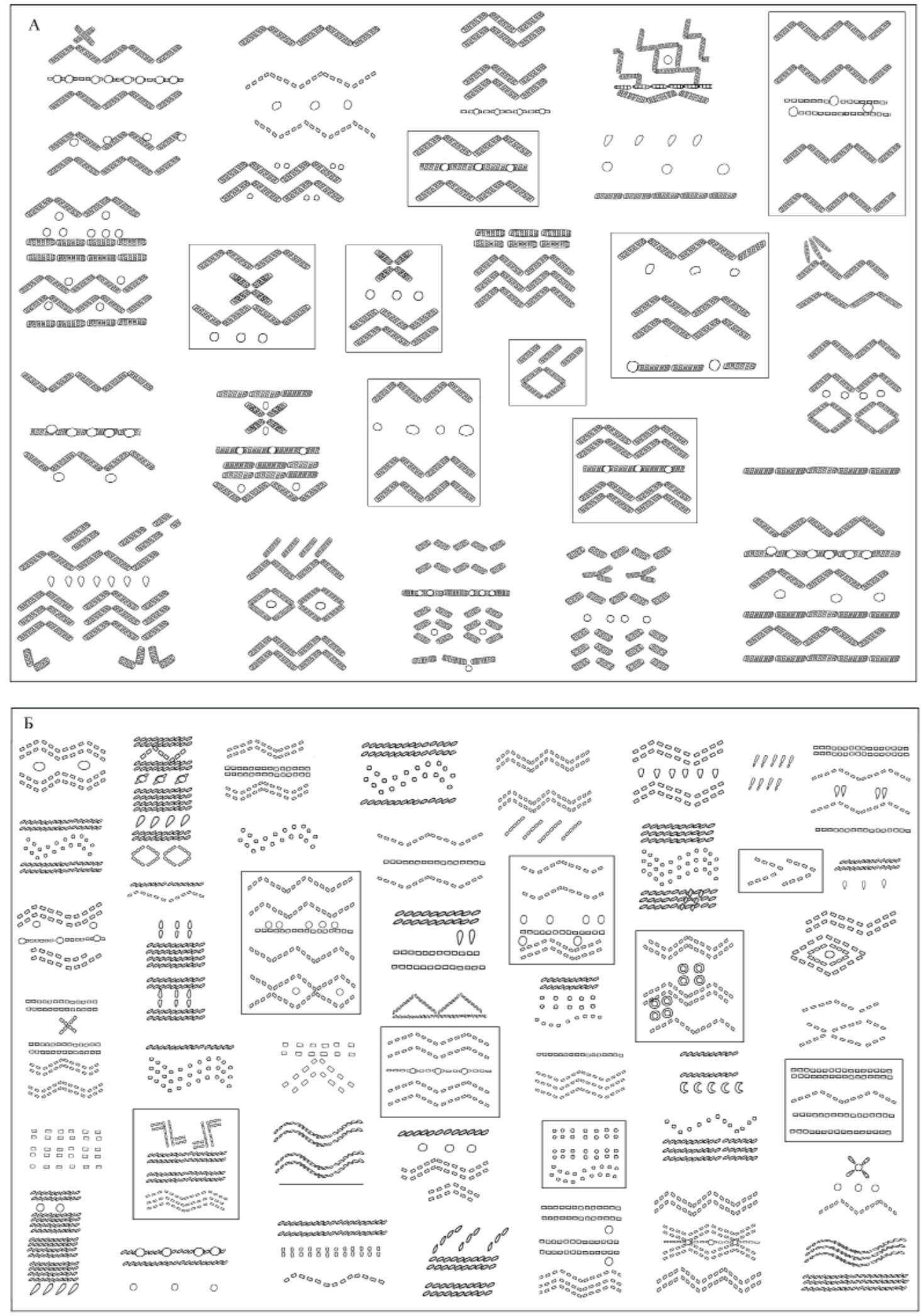

Рис. 14. Основные орнаменты на керамике с рамчатым декором, гибридной посуде (А) и вятско-ветлужской культуры АКИО (Б). Оформление рисунка — Е.В.Рябинина

Fig. 14. Main ornaments on ceramics with a framed decor, hybrid ware (A) and that of the Vyatka-Vetluga culture of the Ananyino Cultural and Historical Region (B). Drawing design - E.V. Ryabinina

они отличаются как по глубине вдавлений, так и по конфигурации дна (рис. 9: 2, 4, 16, 18-24, 25; 10: 1, 17-19; 13: 1-5, 9). Ямки бывают кольцеобразные неглубокие, неглубокие с плоским дном, вдавления средней глубины, но еще не образующие выпуклины с обратной стороны, и глубокие ямки с выпуклинами на внутренней поверхности горшка, при 
этом выпуклины достаточно большие. Дно у глубоких ямок округлое, плоское, реже округло-приостренное (коническое).

Чаще всего из ямок составлены горизонтальные ряды, которые нанесены по шейке (нижней части горловины на месте перехода в плечики), реже они зафиксированы по плечикам. Наблюдаются и ямки, нанесенные по тулову, в т. ч. сквозные (рис. 9: 24).

На сосудах имеются и мелкие вдавления разнообразных форм, среди них выделяются округлые (диаметром 0,1-0,2 см), подтреугольные, каплевидные и клиновидные, а также вдавления в форме полумесяца (скобчатые), выстраивающиеся в горизонтальный ряд, сюжеты составляются и из спаренных мелких ямок. Из мелких вдавлений создаются узоры в виде зигзага и волны, которые часто используется при украшении керамики жителями Одоевского городища. По мнению В.Н. Маркова, такие узоры из мелких ямок на памятниках бассейна р. Вятки неизвестны и характерны для нижнекамских поселений (Марков, 2007, с. 48). На керамике из Одоевского городища зигзаг или волна из мелких вдавлений сочетаются и с трехзубым гребенчатым штампом (рис. 9: 11), такое сочетание характерно и для керамики из третьего слоя Богородского городища (Стоянов, 1959, с. 187).

На одном сосуде две пары ямок образуют квадрат (рис. 9: 22). Делаются ямки и внутри ромбов из гребенчатых оттисков (рис. 9: 2, 21, 26), выполняются и поверх горизонтальной линии из оттисков гребенчатого штампа (рис. 8: 21; 9: 8, 14, 18, 26). Встречаются сосуды с несложным орнаментом, состоящим из горизонтальных рядов вдавлений и одиночных или двойных оттисков шнура (рис. 10: 6, 15, 19).

Глубокие ямки, образующие выпуклины с обратной стороны стенок, зафиксированы на посуде со сложным орнаментом, которая помимо ямок украшена шнуровыми оттисками, расположенными в несколько рядов по шейке, а завершают композицию каплевидные вдавления или насечки (рис. 10: 1, 4), аналогичны по глубине и глазчатые ямки на посуде с гребенчато-шнуровым орнаментом (рис. 9: 4). Вдавления на таких сосудах располагались в одном ряду через примерно одинаковые промежутки.

В коллекции керамики из Одоевского городища встречен всего один сосуд с глазчатыми ямками, найденный в третьем слое городища (Воеводский, 1951), и, судя по всему, наряду со сложно орнаментированной безворотничковой керамикой, он является одним из ранних. Данный сосуд - со сложной орнаментальной композицией, которая начинается парой сдвоенных рядов из шнуровых оттисков; между ними, и частично перекрывая их, наложен зигзаг, выполненный гребенчатым штампом. Далее следует горизонтальный ряд из глазчатых ямок, ниже которого фиксируется полоса из четырехрядных оттисков шнура, которая разграничена от полосы из двух рядов оттисков шнура наклонными каплевидными вдавлениями. Завершается композиция на плечиках ромбами, сделанными из гребенчатых оттисков (рис. 9: 4). Керамика с глазчатыми ямками широко представлена на Богородском городище (Стоянов, 1959, табл. LVI; LVII).

На ветлужских городищах комплексы посуды, включающие керамику, орнаментированную глазчатыми ямками, датированы О.Н. Бадером и В.Е. Стояновым VII-V вв. до н. э. (Бадер, 1951а; Стоянов, 1959). В частности, керамика с глазчатыми ямками отнесена В.Е. Стояновым к ранним комплексам и характерна для 1 и 2 слоя Богородского городища (Стоянов, 1959, с. 184). Бытование посуды с глазчатыми ямками наряду с другой керамикой АКИО на средневолжских памятниках А.X. Халиковым определено в рамках VII-V вв. до н. э. (Халиков, 1962, с. 116). В.С. Патрушев Малахайское поселение, на котором найдена керамика с глазчатыми ямками, датирует более узко, в пределах VII-VI вв. до н. э. (Патрушев, 2017б, с. 109-110, рис. 9-10). Г.А. Архипов ананьинскую керамику из городища Ройский Шихан, которая включает и посуду, украшенную глазчатыми ямками, датировал VII-V вв. до н. э. (Архипов, 1962, с. 203, табл. XLI). Самые ранние материалы ананьинского времени на памятниках Нижнего Прикамья представлены в слоях из городища Гремячий Ключ и Черепашье (Марков, 2007, с. 43). В свою очередь, на городище Черепашье известна лебяжская посуда и ананьинская гребенчато-шнуровая керамика, украшенная глазчатыми ямками (Марков, 2007, рис. 21: 1, 3-4, 6-7; 23: 5, 6; 24: 4). Керамику из городища Черепашье, украшенную глазчатыми ямками, В.Н. Марков определяет во вторую группу (Марков, 2007, с. 37), посуда этой группы соотносится с вятско-ветлужской культурой. Сосуды, относящиеся к этой группе, отсутствуют в слое под насыпью вала, который насыщен керамикой первой группы (Марков, 2007, с. 38), относящейся к ПМК (Чижевский, Хисяметдинова, 2020, с. 93). А.А. Чижевский, 
рассматривая особенности городища Черепашье, основное проникновение носителей вятско-ветлужской культуры на Вятку, Ветлугу и Нижнее Прикамье соотносит с VII-VI вв. до н. э. (Чижевский, Хисяметдинова, 2020, с. 93).

Таким образом, распространение керамики, орнаментированной глазчатыми ямками, в бассейне р. Ветлуги, на Одоевском городище в частности, происходит начиная с VII в. до H. э.

К ранним комплексам керамики из Одоевского городища можно отнести и посуду без воротничков со сложной орнаментальной композицией, составленной в основном из шнуровых оттисков в сочетании с насечками и ямками, образующими выпуклины с обратной стороны, и имеющей в примеси только раковину моллюсков. Такие горшки хорошо представлены на Русенихинском и Богородском городищах. Без внимания не должна остаться и керамика с внутренним ребром на месте перехода высокой прямой или слабоотогнутой шейки в плечики, аналогичная фиксируемой в ранних комплексах I Зуево-Ключевского городища, которая указывает на более раннее время, но это обстоятельство требует дополнительного подтверждения.

Еще раз подчеркнем важную роль оттисков гребенчатого штампа при украшении сосудов Одоевского городища. Многие мотивы на отдельных сосудах выполнены исключительно этой техникой орнаментации. Безусловно, в этом отношении интересны и костяные орнаментиры, найденные на городище во втором слое и использовавшиеся для нанесения гребенчатого штампа на глиняную посуду, в т. ч. для исполнения оттисков с широкой амплитудой шага (Бадер, 1951a, рис. 12: 18-19).

Из оттисков гребенчатого штампа чаще всего составлены горизонтальные линии, зигзаги и ромбы. Выполняются ими и редко встречающиеся сюжеты в виде водоплавающих птичек, крестиков (рис. 9: 25; 12: 22, 28), в одном случае в центре крестика поставлена ямка (рис. 12: 22). Имеются мотивы из короткого двух или трехзубого штампа (рис. 9: 6, 11; $10: 14 ; 11: 3-4,22 ; 12: 14,32 ; 13: 12)$. Линии из оттисков гребенчатого штампа располагаются в один ряд, реже сгруппированы в два или три горизонтальных ряда, иногда они плавно выгибаются в виде невысокой волны (рис. 9: 23). Зигзаги встречаются однорядные, двухили трехрядные (рис. 9: 18, 26; 11: 6, 8, 16, 19, $21,24-25)$. Часто на одном сосуде горизон- тальные линии из оттисков гребенки сочетаются с зигзагом, сделанным в этой же технике (рис. 9: 18, 26; 11: 6, 21, 24-25). Развал горшка, орнаментированный горизонтальной линией и трехрядным зигзагом, найден в нижнем слое, на участке В (рис. 11: 25).

Стоит выделить керамику, украшенную оттисками гребенчатого штампа в сочетании с ямками, иногда и шнуровыми оттисками, образующими более сложные узоры (рис. 9: $2,4,5,14,16,18-23,25,26)$, её количество в коллекции невелико, а также сосуды с простым разреженным и достаточно однообразным гребенчатым орнаментом, представляющим отдельные горизонтальные линии, зигзаги или их сочетание (рис. 11).

Близкая посуда с простым гребенчатым орнаментом известна на Кривоборском и Чижевском городищах (Оруджов, 2017a; Оруджов, Глушков 2019), на Скорняковском городище (Чижевский и др., 2016). На последнем керамика, орнаментированная только гребенчатым штампом, составляет 49\% (Митряков, Черных, 2014, с. 178), что приближено по показателям к Одоевскому городищу. Сходно и соотношение керамики, орнаментированной ямками, на Скорняковском - 8\% (Митряков, Черных, 2014, с. 178), на Одоевском - 7,8\%. В то же время следует обратить внимание на важную деталь: для посуды из вятских городищ присущи воротнички в отличие от керамики из Одоевского городища, сохраняющей основную традицию прямой или слабоотогнутой шейки. Керамика с несложным гребенчатым орнаментом имеет и низкую или среднюю отогнутую шейку, типичную для вятских памятников.

Часто композиция на сосудах с довольно насыщенным гребенчатым орнаментом начинается зигзагом (одно- или двухрядным), в нижней части шейки нанесены горизонтальные линии, в т. ч. сочетающиеся с ямками, ниже на плечиках делаются зигзаги (рис. 9: 18). В одном случае композиция заканчивается ромбами, в середине которых размещена ямка с плоским дном (рис. 9: 26). В коллекции Одоевского городища находится еще один фрагмент, орнаментированный ромбами с ямкой внутри, найденный в слое 2 на участке III/4-5: ямка средней глубины, выпуклину с обратной стороны не образует (рис. 9: 2). Имеется и одна стенка с таким же мотивом (рис. 9: 21). Близкий по исполнению, но не идентичный орнамент имеется на ананьинской керамике из поселения Гремячий ключ, где ямки размещены в ромбах, при этом компо- 
зиция состоит либо из многорядных ромбов, либо из косой решетки (Збруева, 1952, табл. $\mathrm{XV}: 13)$. Ромбы с двумя ямками внутри известны на маклашеевской керамике из поселения Курган (Марков, 2007, рис. 39: 5). Орнаментальные композиции, включающие ромбы, выполненные гребенчатым штампом, но без ямок внутри, известны на городищах Ройский Шихан и Маклашеевском II (Архипов, 1962, табл. XLI, Марков, 1985, рис. 3: 8). Ромбами орнаментируется и керамика из Богородского городища (Стоянов, 1959, табл. LVI; LVII).

Интересен и сосуд, орнаментированный по шейке горизонтальными линиями и крестиками, а по плечикам - двумя двурядными зигзагами (рис. 12: 28). При этом оттиски гребенчатого штампа тонкие, а на крестиках слегка замкнутые в овалы, напоминающие традицию орнаментации керамики рамчатым штампом, однако между оттисками остается большое свободное пространство в отличие от отпечатков классической рамчатой традиции. Отличается этот сосуд от керамики с рамчатым декором и по составу примесей в формовочной массе: изготовлен с примесями раковины и шамота, в отличие от керамики с рамчатым штампом, для которой характерна раковина моллюсков, нагретая на углях. Сюжеты с крестиками известны на ананьинской посуде, о чем говорилось выше.

Следует отметить, что в коллекции с Одоевского городища присутствуют несколько фрагментов стенок с обломанным краем, а также один фрагмент венчика (рис. 9: 14), напоминающих по стилю орнаментации лебяжскую керамику: орнамент представляет собой сложный узор, выполненный элементами только из оттисков гребенчатого штампа (горизонтальные линии, зигзаги и наклонные отрезки), образующих плотно сгруппированные мотивы без чистых полей, иногда сочетающиеся с ямками (рис. 9: 21; 12: 31, 33, 35).

Характеризуя керамику, орнаментированную гребенчатыми отпечатками, необходимо подчеркнуть и различность самих оттисков. На Одоевском городище встречаются сосуды, украшенные гребенчатыми оттисками мелких, средних и крупных размеров. Выделяются оттиски (средние и чаще крупные), сделанные с широкой амплитудой шага. Подобного типа отпечатки имеются на керамике озьягского этапа лебяжской культуры из поселения Яко I (Буров, 1983, рис. 3: 11; Марков, 2007, 28: 5-6), широко поставленные друг от друга отпечатки наблюдаются и на лебяжской керамике из Ардинского, Чутай- ского I, Сухой Берсут и Сорочьегорского городищ (Марков, 2007, рис. 23: 4, 24: 1, 29: 4-5; Чижевский, Хисяметдинова, 2020, рис. 191: 12), расположенных на Средней Волге, в Вятском бассейне и Нижнем Прикамье, встречаются оттиски разреженной гребенки и в комплексах керамики ПМК АКИО на городище Гремячий Ключ (Чижевский, Хисяметдинова, 2020, рис. 186: 17), фиксируются они и на Малахайском поселении (Патрушев, 2017б, рис. 12: 4), подобными отпечатками оформлен один сосуд из Васильсурского II городища (Халиков, 1962, табл. XXVIII). Такими оттисками, как правило, наносятся горизонтальные линии, которые сочетаются с ямками, в отличие от посуды из Одоевского городища, на которой они составляют самостоятельные узоры в виде горизонтальных линий и зигзагов (рис. 8: 19-24; 9: 12; 11: 1; 12: 26), только один фрагмент керамики из Одоевского городища с подобными гребенчатыми оттисками дополнительно орнаментирован глубокими ямками (рис. 8: 21). Выполняются отпечатками такого рода и ромбы (рис. 9: 2). Отпечатки с широкой амплитудой шага отмечены и на керамике маклашеевского облика с Одоевского городища (рис. 12: 23).

Посуда с гребенчатыми отпечатками с широким шагом встречается на памятниках ВВК АКИО. В частности, на Грехневском I поселении известны два сосуда без воротничка со сложным гребенчато-шнуровым орнаментом, сосуды по плечикам украшены линиями и зигзагами, составленными оттисками широкой гребенки (Митряков, Черных, 2014, рис. 16: 17-18). Близкие оттиски можно наблюдать на посуде с воротничком из Чижевского городища, которая, как и керамика из Одоевского городища, ямками не орнаментирована, при этом оттиски отличаются: на сосуде из Чижевского городища они короткие наклонные (Оруджов, Глушков, 2019, рис. 8: 28).

Таким образом, узоры, включающие элементы из гребенчатых оттисков с широкой амплитудой шага в сочетании с ямками, по всей вероятности, могут выступать в качестве раннего признака ананьинской керамики. Гребенчатые оттиски без ямок, очевидно, выражают развитие подобной традиции и могут существовать вплоть до позднего периода АКИО, учитывая, что в формовочную массу кроме раковины начинает добавляться и шамот (прил. 1). Близкий сосуд, отнесенный к позднему периоду АКИО, известен на Аргыжском городище (Чижевский, 2017, рис. 
16: 12). Сосуды, орнаментированные в подобной технике, находятся и в технологической группе Іб Одоевского городища вместе с керамикой без воротничка с высокой шейкой и выпуклыми плечиками, орнаментированной глубокими ямками, образующими выпуклины с обратной стороны, и полосами шнуровых оттисков, и насечками. Эти сосуды изготовлены из среднезапесоченной глины, в примеси которых содержится только раковина моллюсков (прил. 1). Обнаружены фрагменты керамики, орнаментированные гребенчатыми оттисками с широкой амплитудой шага, в основном в слое 2 , в частности на участке $\mathrm{A}$, в нижней части.

Фиксируются и гребенчатые отпечатки, плотно поставленные друг к другу (они, как правило, меньших размеров), характерные для керамики из поселений вятско-ветлужской культуры АКИО.

В целом более высокая доля именно оттисков гребенчатого штампа при орнаментации керамики вятско-ветлужской культуры АКИО из Одоевского городища может указывать на бережное сохранение лебяжских орнаментальных традиций.

Обратимся с этим сюжетом и к материалам Юго-Западного Прибеломорья. Гребенчатый штамп с широкой амплитудой шага известен на синхронных лебяжским памятниках с керамикой типа Бохта II (Жульников, 2005, рис. 100: 10, 104: 1, 11, 105: 1, 8). Основные сюжеты, выполненные подобным штампом, также представлены горизонтальными линиями, которые сочетаются с ямками. А.М. Жульников на основании лебяжских орнаментальных традиций и форм сосудов указывает на восточное происхождение керамики типа Бохта II (Жульников, 2005, с. 34). Известна керамика с широкопоставленными оттисками гребенчатого штампа и на памятниках финала бронзы - РЖВ с сетчатой керамикой в окрестностях Галичского озера и Костромской низины (городище Брюхово, поселение Ватажка) (Новиков, 2019, рис. 3: 21, 7: 2; Новиков, 2020, рис. 19: 12).

Отметим высокую мобильность и активность населения лебяжской культуры в финале эпохи бронзы - самом начале раннего железного века. Небольшие разбросанные коллективы этой культуры имеют широкую географию расселения. Носители лебяжских традиций продвигаются на запад, достигая пределов Юго-Западного Прибеломорья, где их присутствие отмечается в формировании керамики типа Бохта II, и на юго-запад, доходя до Волжского бассейна, где на Малахайском поселении и Ардинском городище известна лебяжская керамика, в Поветлужье она найдена на Богородском городище. Предварительно можно говорить о распространении носителей лебяжских традиций на Ветлуге в самом начале I тыс. до н. э. Судя по всему, на Ветлуге происходят контакты и с носителями рамчатых керамических традиций, о чем свидетельствуют наличие гибридной керамики, а также стиль орнаментации части посуды с рамчатым штампом, фиксирующейся на Одоевском городище, что отмечалось выше. Носители керамики с рамчатым декором «одоевского типа» заселяют данное место, вероятно, еще в финале эпохи бронзы, что подтверждают и редкие находки керамики маклашеевского облика, сделанные на городище. В этой связи обратим внимание на весьма важное предположение В.Н. Маркова о том, что лебяжская керамика на памятниках Нижнего Прикамья следует за маклашеевской и хронологически с ней не связана (Марков, 2007, с. 45). Вероятно, на это обстоятельство указывают и керамические материалы из Одоевского городища, подчеркнем только, что они не имеют четких стратиграфических привязок, выделены типологически в смешанных комплексах, находящихся в нижних слоях. На Богородском городище керамика маклашеевского облика и сетчатая посуда характеризуют первый (ранний) слой (Стоянов, 1959, с. 181-182, табл. LV).

Мотивы, составленные из шнуровых оттисков, при украшении керамики вятско-ветлужской культуры АКИО Одоевского городища играли менее заметную роль, в отличие от орнамента, сделанного гребенчатыми отпечатками.

Определяемая структура шнуровых оттисков тонкая и толстая. Направление оттисков (при определенном положении шнура) - правонаклонное или левонаклонное. Для керамики из Одоевского типичны оттиски с правым уклоном.

Выделяется небольшая группа керамики, типичная для вятско-ветлужской культуры АКИО, орнаментированная в два, три или четыре горизонтальных ряда шнуровых оттисков, расположенных вплотную друг к другу и отделенных свободным неорнаментированным пространством или другими элементами орнамента. На керамике, орнаментированной шнуровыми оттисками по шейке, имеется и поясок из глубоких ямочных вдавлений, типичных для раннеананьинской посуды, 
образующих выпуклины с обратной стороны (рис. 9: 4; 10: 1, 17, 18). Такая посуда характерна и для Богородского, и Русенихинского городищ. Имеются мотивы из вплотную расположенных оттисков одного шнура без разделителей (рис. 8: 14; 10: 13), встречаются оттиски шнура со своеобразным разделителем, когда шнуровые оттиски первой линии четырехрядной полосы более глубокие и чёткие. Этот сосуд по шейке орнаментирован пояском из глубоких ямок, а завершают композицию насечки. Данный горшок может считаться одним из ранних (рис. 10: 17). На одном сосуде полоски, составленные из двух и четырех рядов шнуровых оттисков, сочетаются с двузубым гребенчатым штампом (рис. 10: 14). Встречается керамика с волной или зигзагообразно изгибающимися линиями из оттисков шнура, иногда спаренными или расположенными по три (рис. 8: 12, 13, 18; 9: $1 ; 10: 7-8)$, на одном фрагменте они сопровождаются и мелкими вдавлениями (рис. 9: 1). Керамика, орнаментированная волной из шнуровых оттисков, имеется на Скорняковском городище (Митряков, Черных, 2014, рис. 17: 5, 11; Чижевский и др., 2016, рис. 40: 2), менее, но заметна она и в комплексах керамики Одоевского городища. А.А. Чижевский указывает, что такая керамика имеет большое хронологическое распространение, встречается на ананьинских памятниках начиная с VIII в. до н. э. и присутствует в комплексах до V-IV вв. до н. э. (Чижевский и др., 2016, c. 46$)$.

В коллекции керамики, орнаментированной волной или зигзагообразными линиями из шнура, выделяется фрагмент одного сосуда, украшенного по шейке однорядным зигзагом из оттисков толстого шнура, подчёркнутого горизонтальной линией, выполненной этими же оттисками (рис. 8: 18). Близкая керамика найдена на раннегляденовском поселении у д. Севастьяны близ г. Перми (Мокрушин, 1992, рис. 2: 5). Определяя особенности севастьяновской керамики, Мокрушин В.П. сближает ее с позднеананьинской (Мокрушин, 1992, с. 109).

Имеется в коллекции из Одоевского городища и керамика, на которой сочетаются мотивы, выполненные шнуровыми оттисками и гребенчатыми отпечатками (рис. 9: 4, 25; 10: $7,10,12)$ или прочерченной линией (рис. 8: 1).

Присутствует посуда с разреженным несложным орнаментом, представленным одиночными горизонтальными линиями из шнуровых оттисков или полоской из двух рядов оттисков шнура (рис. $8: 5,6,10,15 ; 10$ : $3,5-6,8,9,15-16,19)$. Орнаментальные мотивы, как правило, состоят из двух элементов. Часто на такой керамике можно увидеть сочетание простых линий шнуровых оттисков с поясками из ямок, ряды из ямок располагаются в нижней части шейки и по плечикам (рис. 10: 6, 15, 19), ямки небольшого размера. Орнаментацию сосудов мелкими вдавлениями на вятских памятниках АКИО Э.И. Оруджов определяет как поздний признак ананьинской керамики, основываясь на предположениях С.Н. Коренюка (Оруджов, 2017а, с. 91), однако на керамике из Одоевского городища они использованы в т. ч. и для составления относительно сложных узоров в виде волны, как и на памятниках Прикамья. Вместе с тем мелкие ямки и узоры, ими составленные, характерны для керамики из третьего слоя Богородского городища (Стоянов, 1959, с. 187). Присутствуют на посуде из Одоевского городища пояски из подтреугольных и клиновидных вдавлений, не идентичных, но близких белогорскому типу керамики. У одного горшка вдавления в форме полумесяца (или скобчатые) нанесены по плечикам (рис. 10: 6). На другом горшке с валиковым выступом мелкие ямки, образующие волну, сочетаются с многорядными оттисками шнура (рис. 10: 4). Посуда с простым шнуровым орнаментом второго морфологического типа чаще имеет высокую шейку. По стилю орнамента и форме верхней части такая керамика напоминает посуду ПМК АКИО. В частности, несложный орнамент характерен для керамики ПМК АКИО Казанской стоянки (Чижевский и др., 2019, с. 127-128). А.А. Чижевский существование поселений ПМК АКИО доводит до IV/III вв. до н. э. (Чижевский, 2017). Близкий по стилю орнамент можно наблюдать и на керамике ПМК АКИО из памятников Нижнего Прикамья (Марков, 2007, рис. 15: 1, 16: 9, 19: 2). Вместе с тем выделим важный момент: ямки на керамике ПМК АКИО глубокие и зачастую образуют выпуклины с обратной стороны, в отличие от посуды из Одоевского городища, на которой они неглубокие и меньших размеров. Схожая по стилю орнаментации позднеананьинская посуда известна в бассейне р. Белой (Чижевский, 2017, рис. 14: 15, 19). В формовочную массу керамики с простым орнаментом добавляется раковина и шамот. Таким образом, наиболее вероятное время распространения подобной керамики на Одоевском городище может приходиться на позднеаньинский период, когда на поселении появляется собственно 
и сетчатая керамика, но, судя по нахождению достаточно больших склеивающихся фрагментов от двух горшков, орнаментированных по краю (рис. 10: 15, 19), в нижнем слое на участке Д, не исключено и более раннее время появления такой посуды на городище, в VI-V вв. до н. э. На Богородском городище посуда с простым шнуровым орнаментом присутствует и в ранней группе керамики, В.Е. Стоянов определяет её как керамику с неспецифичными орнаментальными композициями (Стоянов, 1959). В целом между керамикой Богородского и Одоевского городищ наблюдается много общих, пересекающихся характеристик, как орнаментальных, так и морфологических.

Таким образом, ананьинская посуда из Одоевского городища изготавливалась преимущественно из незапесоченных и слабозапесоченных глин с примесью в формовочной массе раковины, раковины и шамота или шамота с органическими остатками. Горшки округлодонные, преобладают с прямой или слегка отогнутой шейкой, слабовыпуклыми, реже выпуклыми плечиками. Большинство сосудов имеют плоский край, иногда орнаментированный. При орнаментации керамики чаще всего использовался гребенчатый штамп, реже - в сочетании с ямками, еще реже - с шнуровыми оттисками.

\section{3. Сетчатая керамика}

В третью группу выделена сетчатая керамика (рис. 13: 19-33). Керамика найдена в основном во 2 слое, а также собрана с поверхности, ее присутствие документируется и в слое 1 (вероятно, переотложена). В коллекции Одоевского городища насчитывается небольшое количество фрагментов такой керамики (около 30), что составляет 1\% от всей керамики из раскопок Б.С. Жукова и О.Н. Бадера, еще 2 фрагмента собраны на городище Н.M. Бекаревичем в 1903 г. (рис. 13: 22). Предметы хранятся в ОГБУК «Костромской государственный историко-архитектурный и художественный музей-заповедник» (КМЗ КОК $15306,15307)$. Коллекция собранных на городище Н.M. Бекаревичем предметов состоит из фрагментов керамики и каменных изделий. Общее количество находок составляет 39 шт. О.Н. Бадер керамику с текстильными отпечатками относил к началу I тыс. н. э. (Бадер, 1951a, c. 154).

По фрагментам верхних частей выделяется не более 5 сосудов. Сетчатая керамика исключительно слабопрофилированная, с низкой, слегка отогнутой шейкой, и высо- кой, практически прямой шейкой, плечики низкие приспущенные, слабовыпуклые (рис. 13: 19-23). Посуда неорнаментированная. Край оформлен однообразно, как правило, округлый, реже плоский, без утолщений. Два горшка орнаментированы по краю косопоставленными насечками. Черепки плотные. Керамика коричневых, серых и темно-серых цветов. С внутренней стороны поверхность керамики заглажена. Толщина стенок посуды составляет от 0,35 до 0,6 см, в среднем 0,4-0,5 см. Изготавливалась керамика из глины с естественными примесями кварцевого песка, в состав формовочной массы добавлялись минеральные примеси в виде шамота. Присутствует и органический раствор, определённый как выжимка из навоза жвачных животных. В сетчатой керамике из коллекции Н.М. Бекаревича встречается и дресва.

Внешняя поверхность посуды декорирована рябчатыми и нитчатыми отпечатками. Рябчатые отпечатки мелкоячеистые и крупноячеистые, хаотично расположенные. Встречаются отпечатки узкой ногтевидной формы. Отпечатки чаще четко вдавленные, редко встречаются слабо вдавленные, подзатертые. Сетчатая керамика с нитчатым отпечатком встречается реже. Структура нитей мелкая, накладывались они как горизонтально, так и вертикально под углом, при этом на поверхности могли оставаться и заглаженные участки (рис. 13: 33). На одном черепке встречены хаотично наложенные нитчатые отпечатки.

В коллекции имеется и один фрагмент с рогожными отпечатками: отпечатки подпрямоугольные большие, с внутренней стороны черепок заглажен.

У керамики с Одоевского городища отсутствуют общие признаки (орнамент, степень выпуклости плечика, общая морфология верхней части горшка), за исключением сетчатой обработки внешней поверхности рябчатыми и нитчатыми отпечатками, с текстильной посудой акозинской культуры АКИО, в частности, найденной на Ардинском, Сиухинском, Васильсурском II, Сомовском II и Богородском городищах (Патрушев, 2017a, рис. 3-6; Михеев, 2017, рис. 9-10; Ефремова, Соловьев, 2014, рис. 13; Халиков, 1962, табл. ХХХ; Никитин, Соловьев, 2001, рис. 8: 3-10; Стоянов, 1959). Отличается сетчатая керамика из Одоевского городища и от акозинской керамики из других поселений АКИО (Кузьминых, Чижевский, 2009, рис. 10; Чижевский, Галимова, Губайдуллина, 2019, рис. 12). 
В свою очередь, на поселенческую активность носителей сетчатых керамических традиций на берегах р. Ветлуги в акозинское время, очевидно, и ранее, в поздний период эпохи бронзы, может указывать сетчатая керамика, найденная на Пановской стоянке (Бадер, 1951б, с. 19) и в нижних слоях Богородского городища (Стоянов, 1959, с. 162, 181), однако её еще предстоит изучить, как и сетчатую посуду, обнаруженную на Нагорном, Богородском, Подушкино 2 поселениях и городище Селиваниха 1. Вызывает интерес фрагмент сетчатой керамики, относящийся к акозинской культуре АКИО, орнаментированный под венчиком пояском из глубоких ямок, образующих выпуклины с обратной стороны, найденный на поверхности западного склона Богородского городища А.А. Пудеевым (2010, рис. 12). Он отмечает, что городище продолжает разрушаться в результате природного и антропогенного факторов, культурные слои повреждены (Пудеев, 2010, с. 87-88). Ещё раз повторим, что поселения с сетчатой керамикой Поветлужья сейчас изучены слабо.

Слабопрофилированная неорнаментированная сетчатая керамика присутствует на памятниках РЖВ в бассейне Верхней Волги, таких как поселения Ватажка, Брюхово, Вознесенское II и др., а так же Пеньковском, Минском и Серюпитинском городищах (Гурина, 1963, рис. 69: 3-4; Столяр, Хлобыстин, 1963, рис. 4, 7; Новиков, 2019, рис. 2; 2020; Новикова, 2020, рис.4). Однако особенность поселений, известных в восточной части Верхневолжского бассейна, выражена в многослойности и смешанности комплексов сетчатой керамики, зачастую сетчатая керамика финала бронзы и раннего железного века находится на поселениях в одних слоях.

Относительно чистый комплекс сетчатой керамики подобного облика (прямое, не четко выраженное горло, переходящее в слабовыпуклые бока) зафиксирован на Серюпитинском городище и выделен в группу 1 (Столяр, Хлобыстин, 1963, с. 231, рис. 4-5, 7: 1-10). Внешняя поверхность этой посуды декорирована рябчатыми и нитчатыми отпечатками, керамика датирована IV-III вв. до н. э. - I в. н. э. (Столяр, Хлобыстин, 1963, с. 238), а учитывая, что на Серюпитинском городище имеется и гибридная керамика с ананьинскими и сетчатыми признаками, довольно просто орнаментированная только линиями из оттисков шнура, близкая комплексам посуды № 2 и 3 «типа Ватажки» ((Новиков, 2017, рис. 6; 2018 , с. 81)), время бытования этого комплек- са в рамках IV-III/II вв. до н. э. выглядит вполне убедительным. Сочетание гибридной керамики и сетчатой слабопрофилированной с рябчатым отпечатком отмечается и на Пеньковском городище (Новиков, 2019, рис. 2). Кроме того, на этих городищах отсутствуют собственно ананьинская керамика и керамика первого этапа развития поселений со смешанными ананьинским (вятско-ветлужской культуры АКИО) и сетчатыми признаками (Новиков, 2017; 2018; 2019; 2020).

Выделим доминирующую традицию декорирования поверхности сетчатой керамики из памятников Костромского Поволжья именно рябчатыми отпечатками, которые характерны и для сетчатой керамики из поселений более северных территорий, в частности Посухонья. Сетчатая керамика с рябчатым отпечатком занимает существенное место и в коллекции сетчатой посуды из Одоевского городища.

Судя по стилистическим особенностям, характеру обработки внешней поверхности, сетчатую керамику из Одоевского городища можно соотнести с позднеананьинским периодом и датировать в пределах конца V-III/II вв. до н. э. Появление минеральных примесей в виде шамота в позднеананьинской посуде может связываться именно с распространением в данных областях сетчатой керамики.

Во втором слое Одоевского городища обнаружено небольшое количество фрагментов от плоских днищ с закраиной (Жуков, Бадер, 1925-1926; Воеводский, 1951, с. 160), характерных для сетчатой керамики из памятников раннего железного века восточной части Верхневолжского бассейна, где эта традиция преобладает (Гурина, 1963, рис. 67, 40: 9-10; Новиков, 2015, рис. $14 ; 2018$, рис. $110 ; 2020$, рис. 22: 2-3, 26: 5; Столяр, Хлобыстин, 1963, рис. 7: 15). Сетчатая керамика с плоскими донцами в небольших количествах встречается на Ардинском, II Васильсурском и II Сомовском городищах (Архипов, Патрушев, 1982 , с. 55 ; Халиков, 1962, с. 148 ; Никитин, Соловьев, 2001, с. 13). Один сосуд с плоским дном и примесью песка обнаружен на Старшем Ахмыловском могильнике (Патрушев, Халиков, 1982, с. 44; Патрушев, 1984, с. 59). В целом посуда с плоским дном появляется на памятниках, расположенных в западной части ананьинского культурного пространства и обязательно пересекающихся с текстильным миром.

Таким образом, локальным своеобразием Одоевского городища являются смешанные керамические комплексы: «одоевского типа» 


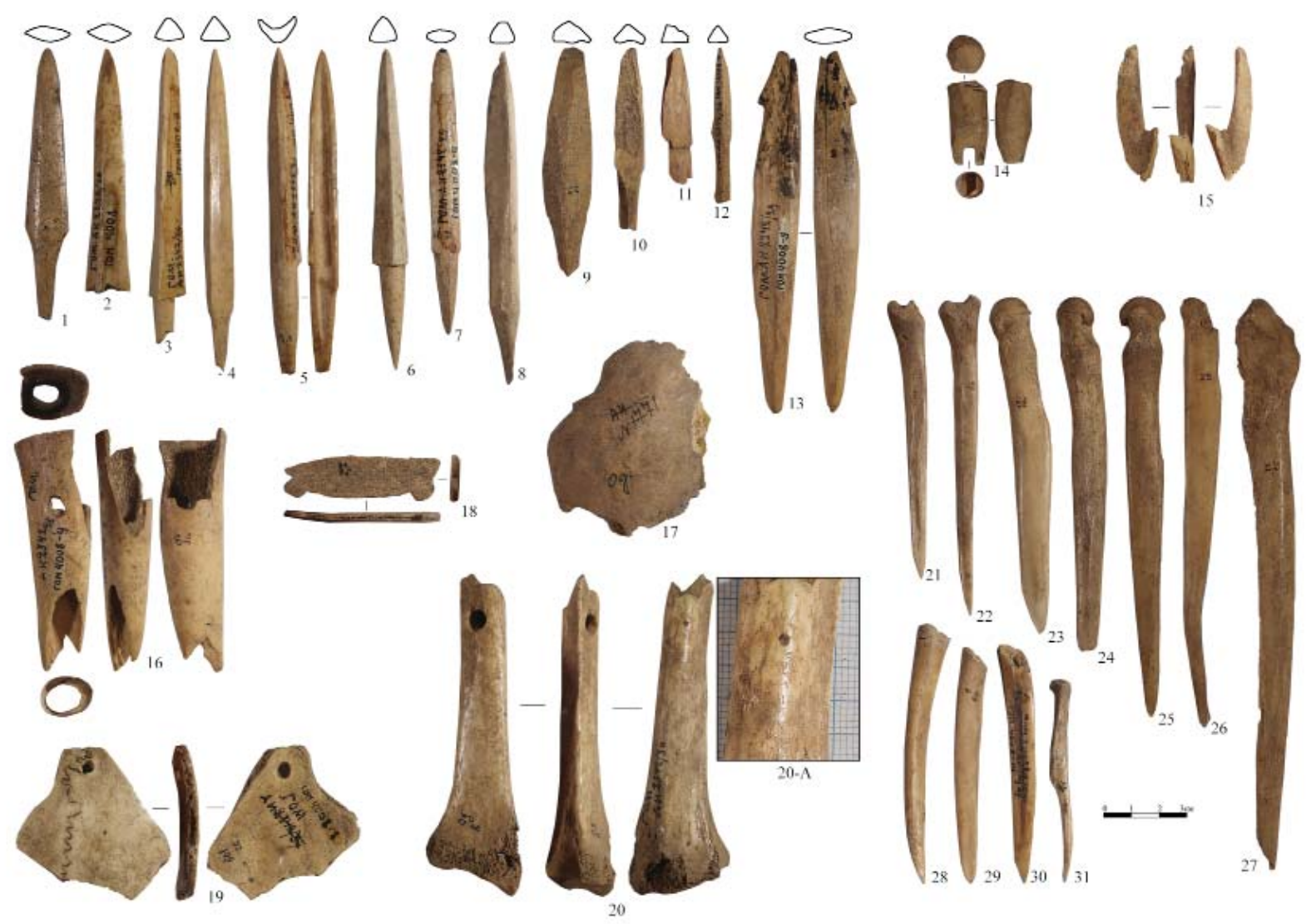

Рис.15. Изделия из кости вятско-ветлужской культуры АКИО.

Культурный и хронологический контекст находки под №19 не определён

Fig. 15. Bone items of the Vyatka-Vetluga culture of the Ananyino Cultural and Historical Region.

Cultural and chronological context of find No. 19 is undefined

с рамчатым декором, ВВК АКИО, сетчатой керамики. Богатый керамический набор отразил сложную историю памятника в I тыс. до н. э. Далее перейдем к рассмотрению изделий из кости и камня, найденных во 2 и 3 слое городища.

\section{Предметы индивидуального облика}

Довольно полный обзор индивидуальных изделий, найденных на Одоевском городище, представлен в статье О.Н. Бадера (1951а, с. 123-131). Вещи относятся к разным периодам освоения площадки городища, в том числе значительная категория находок из кости связана с собственно ананьинским временем (происходит из второго слоя) и ярко отображает особенности вятско-ветлужской культуры АКИО (Бадер, 1951a, рис. 12, 13: 1-12). Имеются предметы и постананьинской эпохи, а учитывая, что на городище выделен комплекс керамики предананьинского времени, часть находок могут быть отнесены и к нему, особенно изделия из камня.

Акцентируем внимание на некоторых находках.

Предметы производственного характера, связанные с металлообработкой, представлены обломками глиняных тиглей, найденных на уч. I/1 и III в нижнем слое. Стенки толстые, их структура пористая (губчатая). Тигли побывали в производстве. Внешняя поверхность растрескавшаяся, внутренняя поверхность одного фрагмента ошлакованная, гладкая и немного блестящая, другого - ошлакованная губчатая (рис. 16: 46, 47). В коллекции выделяется еще один фрагмент глиняной толстой стенки с бортиком, со следами копоти на внешней поверхности. Внутренняя сторона не ошлакована. Длина 8 см, толщина около 0,8 см (рис. 16: 48). Вероятно, это фрагмент тигля, не побывавшего в употреблении.

Охотничье-промысловый комплекс находок ананьинского времени представлен изделиями из кости и рога, включая их заготовки.

На городище найден один весьма интересный предмет (рис. 15: 14). Обнаружен он во втором слое на участке А и интерпретирован О.Н. Бадером как «цилиндрический кусок кости с глубоким пазом с одного конца» (Бадер, 1951a, с. 129). Вероятно, этот предмет представляет собой наконечник стрелы подцилиндрической формы с затупленным концом и прорезью на месте насада (раздвоенный насад). Длина предмета составляет 2,5 см, диаметр около 1,2 cм, слегка сужается 

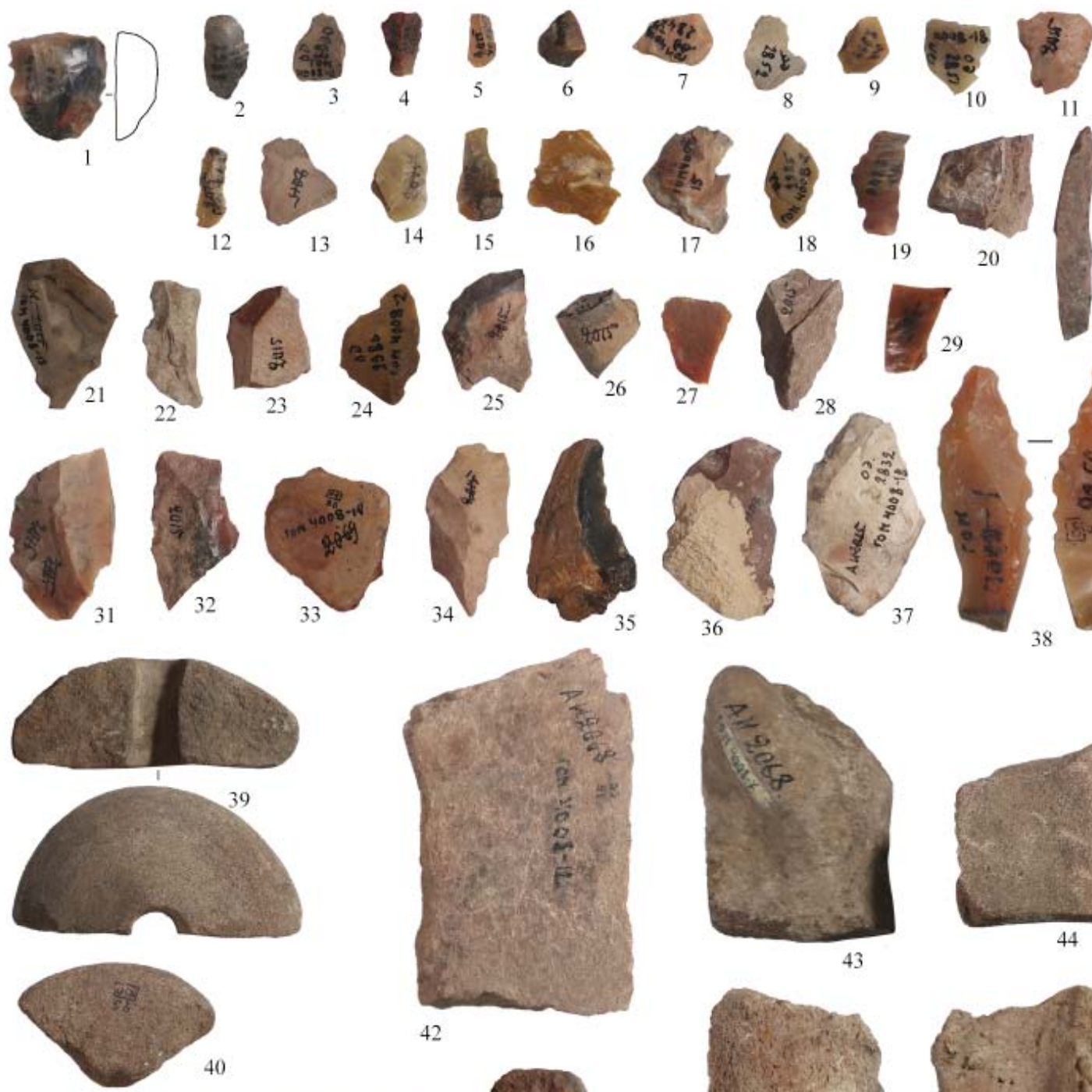

43

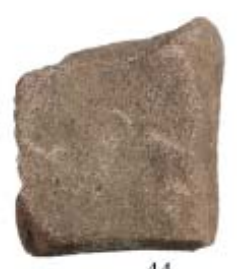

42
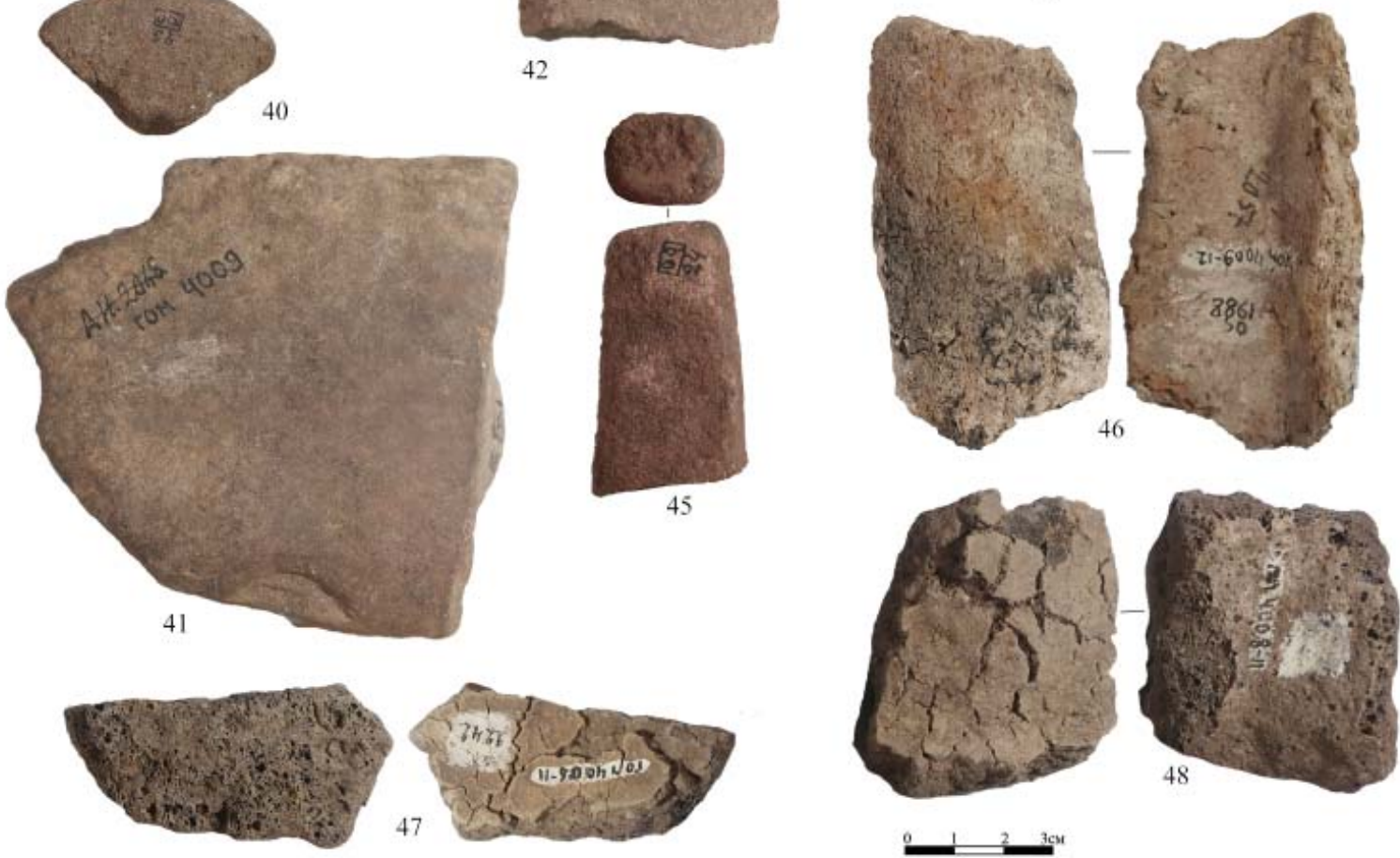

Рис. 16. Изделия из камня (1-45) и глины (46-48)

Fig. 16. Stone (1-45) and clay (46-48) items

к насаду. Глубина прорези около 0,5 см. Для сравнения можно обратиться к схожим по типу, но не идентичным наконечникам стрел, в т. ч. с тупым концом, имеющимся на Дьяковом городище и датированным в пределах
V-II вв. до н. э. (Кренке, 2019, с. 53, рис. 99: 9, 11-12). При сопоставлении наконечников из кости с затупленным острием из Дьякова и Одоевского городищ можно отметить их близкие формы и размеры, оформление кончика и 
общее функциональное назначение. Подобные наконечники (т. н. томары) предназначены для охоты на небольшого пушного зверька, что указывает на развитие пушного промысла у жителей Одоевского городища. Единственное кардинальное отличие наконечников стрел из Дьякова и Одоевского городищ - это способ крепления передней части к древку. Если для дьяковских наконечников стрел характерна классическая втулка, то наконечник из Одоевского городища - с раздвоенным насадом. Конечно, интерпретация находки из Одоевского городища не так однозначна, и этот предмет вполне мог выполнять роль костяной рукояти, схожие, но опять же с втулкой, известны на Дьяковом городище (Кренке, 2011, рис. 9, 90, 104).

Таким образом, данная находка, а также небольшое количество сетчатой керамики РЖВ, обнаруженной во втором слое, могут документировать наличие культурных связей населения Одоевского городища с носителями сетчатых керамических традиций в позднеаньинский период, именно в это время ориентированность носителей ВВК АКИО на запад и северо-запад, в традиционные районы поселений с сетчатой керамикой, стала определяющей для культурного взаимодействия. Напомним, что на городище найден и один фрагмент рогожной посуды городецкого облика.

Изготовление наконечников стрел из кости со втулкой или раздвоенным насадом не свойственно носителям ананьинских культурных традиций, для которых типичны исключительно черешковые костяные наконечники стрел, начиная с раннеананьинского периода. Их образ хорошо известен и представлен в литературе, исследователи неоднократно обращались к типологии этих изделий (Збруева, 1952 табл. IX, XLI, XIX; Халиков, 1977, рис. 76Б; Ашихмина, Черных, Шаталов, 2006; Ашихмина, 2014, рис. 57: 8-9, 61:1-2; Митряков, Черных, 2014, рис. 8; Чижевский и др., 2016, рис. 47: 3, 7; Патрушев, 2011, рис. 24; Архипов, 1962, табл. XL, 1-5 и др.). Определяя особенности ананьинских костяных наконечников стрел, А.В. Збруева отметила, что все они черешковые и чаще всего трехгранные и четырехгранные (Збруева, 1952, с. 51), при этом костяных наконечников к концу ананьинской эпохи становится меньше (Збруева, 1952, с. 92). Только на Старшем Ахмыловском могильнике в погребении 925 был обнаружен втульчатый наконечник (Патрушев, 2011, рис. 24), отличающийся по форме от находки из Одоевского городища. Втульчатые наконечники характерны для дьяковской среды (Смирнов, 1974, с. 29).

В широком употреблении костяные черешковые наконечники стрел были и у жителей Одоевского городища. По типу сечения преобладают трехгранные костяные наконечники, имеются и четырехгранные (подтрапециевидные), с выемкой, и уплощенно-линзовидные (рис. 15: 1-8). Найдены наконечники во втором и третьем слое (участок $Г-$ низ, участок III/11 - нижний слой, участок III/78 - первая нефедовская яма и т. д.). Присутствуют в коллекции и заготовки черешковых костяных наконечников стрел (рис. 15: 9-12). На поселениях АКИО бассейна р. Вятки наконечники с трехгранным пером и едва наметившимся переходом к черешку являются наиболее массовыми (Митряков, Черных, 2014, с. 161, рис. 8), что характерно и для Одоевского городища.

Обломки «мотыжек» или копий (штыков) найдены во втором слое городища (рис. 15: 16), всего в коллекции их насчитывается пять (Бадер, 1951a, с. 126, рис. 13: 3-5). Такие на вятских памятниках встречаются часто и составляют большие доли в коллекциях костяных изделий, в частности, на Буйском городище их найдено 58, на Аргыжском - 28, самая массовая коллекция происходит с Пижемского городища (Митряков, Черных, 2014, с. 161, 163).

Из орудий, связанных с рыбной ловлей, стоит отметить костяной наконечник гарпуна или остроги, который в коллекции представлен в единственном экземпляре (рис. 15: 13). Найден предмет в среднем слое (участок III/9), его длина 13,8 см. Для вятского ананьина это также типичная находка (Митряков, Черных, 2014, с. 163). Имеются в коллекции и рыболовные костяные крючки (рис. 15: 15) (Бадер, 1951a, рис. 13: 6-11). На заметную роль рыболовства наряду с охотой указывает и большое количество рыбьих костей (в т. ч. стерляди и сома), а также скопления чешуи, зафиксированные в культурном слое Одоевского городища (Бадер, 1951a, с. 133).

Результаты остеологического анализа костных останков из Одоевского городища представлены А.Н. Формозовым (1951, с. 181-186) - это достаточно подробное описание костей, дающее представление о характере хозяйствования жителей Одоевского городища в ананьинское время. Объектами охоты являлись медведь, куница, выдра, рысь, бобр, заяц, северный олень и лось. Преобладание 
во втором слое костей бобра даёт основания говорить о важности пушного промысла для экономики поселения. На значимость для ананьинцев промысловой добычи бобра указывала и А.Г. Петренко (2007, с. 70). Останки домашних животных на Одоевском городище представлены костями свиньи, коровы и лошади. Кости птиц немногочисленны, среди них отмечены лебедь и глухарь. А.Г. Петренко, анализируя остеологические коллекции АКИО, отмечала, что основное место в домашнем стаде ананьинского населения принадлежало лошади, большое значение в хозяйствовании занимало также выращивание крупного рогатого скота и свиней (Петренко, 2007, с. 67-68, 73). Разведение этих домашних животных характерно и для Одоевского городища, что указывает схожий тип хозяйствования ананьинского населения из Одоевского городища и других памятников АКИО.

В ананьинском слое Одоевского городища найдена костяная плоская накладка (участок III/9, нижний слой) (рис. 15: 18). Отметим и две костяные орнаментированные лопаточки со втулками, одна из которых происходит из нижнего слоя уч. III/9 (Жуков, Бадер, 1925-1926; Бадер, 1951a, рис. 12: 43-44, с. 128-129). Такие предметы характерны для ВВК АКИО, их большое разнообразие наблюдается именно в вятском ареале АКИО (Митряков, Черных, 2014, с. 163). Многочисленную категорию вещей из кости составляют также кочедыки, проколки и различные острия, найденные во втором слое (рис. 15: 21-31), (Бадер, 1951a, рис. 12, 11-17, 21-27).

В целом по составу костяных изделий отчётливо прослеживается культурная близость поселений АКИО бассейна рек Ветлуги (Одоевского городища в частности) и Вятки. Об этом же говорит и стилистика орнаментации ананьинской посуды. Региональные же отличия керамики ВВК АКИО, рассмотренные выше, обосновываются как географическим расположением памятников, так и культурной спецификой областей, основанной на степени взаимодействия с другими культурными группами внутри ананьинского мира, а также связанной с воздействием внешних культурных областей.

Остановимся еще на некоторых интересных, на наш взгляд, находках. Это предметы из человеческих костей. В истории известны примеры использования человеческих останков в ритуальных целях, связанных с врачеванием. С определением хронологической позиции и культурной принадлежности части таких находок из Одоевского городища сейчас возникает сложность, так как стратиграфический контекст не выяснен, тем не менее рассмотрим эти предметы. Автор выражает благодарность д.и.н. С.В. Васильеву за консультации, оказанные при определении принадлежности костей человеку. Один амулет вырезан из черепа человека и представлен в виде двух теменных костей с сагиттальным швом, найден он в 1925 г. (уч. III/11, В горизонт). Амулет имеет сквозное отверстие диаметром от 0,35 до 0,5 см, которое расширено с внутренней части черепной коробки. Предмет шестиугольной неправильной формы. Поверхность с двух сторон залощена (рис. 15: 19). О.Н. Бадер указывал, что череп принадлежал пожилому человеку (Бадер, 1951a, с. 131). Возможно, данный предмет указывает на практику трепанации. Похожий амулет, вырезанный из теменной и лобной костей человеческого черепа, со сквозным отверстием был найден на городище Ф.Д. Нефедовым (Бадер, 1951a, рис. 13: 35) и описан Д.Н. Анучиным, который также подробно изложил взгляды Поля Брока на практику трепанирования (Медникова, 2018, с. 18). По мнению М.Б. Медниковой, относительно традиции изготовления амулетов Д.Н. Анучин, скорее всего, был солидарен с Брока: люди, страдавшие нервными расстройствами и оперированные при жизни, считались одаренными особыми свойствами. Череп воспринимался как вместилище духа, и когда такой человек умирал, у соплеменников возникало желание воспользоваться в религиозных целях частями его краниума (Медникова, 2018, с. 19). Важные аспекты обрядовой деятельности, основанной на практике трепанации у берберов шауйя, включающей и высверливание отверстий в черепах, рассмотрены М.Б. Медниковой (2018, с. 97-106).

Кроме амулетов из частей человеческих черепов со сквозными отверстиями на Одоевском городище на уч. Г найден кусок теменной кости ребенка с неровными краями (рис. 15: 17). Кость неправильной (шестиугольной) формы, размеры 6-7×3-5,8 см. Б.С. Жуков и О.Н. Бадер указывают, что кость черепа имеет следы распила. Возможно, это трепанированная часть черепной коробки. Также в нижнем слое на уч. А обнаружена и нижняя часть лучевой кости взрослого человека с круглым отверстием (рис. 15: 20). С одной стороны диаметр отверстия составляет 7 мм, с проти- 
воположной стороны оно совсем маленькое, диаметр около 2 мм. Амулет хорошо заглажен. Несомненно, вызывают интерес мелкие нарезки, выполненные по одному из краев кости рядом с отверстием и составленные в один ровный ряд. Длина каждого элемента около 1 мм, интервалы между ними примерно одинаковые и составляют 0,5-0,8 мм (рис. 15: 20A). Эти две находки сделаны в слое с ананьинской керамикой.

Теменная кость со следами распилов, принадлежащая ребенку, могла являться и свидетельством обрядов человеческих жертвоприношений, известных на памятниках поздней стадии ананьинской культуры Среднего и Нижнего Прикамья, где детские жертвоприношения преобладают (Коренюк и др., 2017, с. 152).

\section{Каменные изделия}

Каменная индустрия по-прежнему играет важную роль, предметы из камня занимают существенное место в коллекции находок из Одоевского городища, количество предметов достигает 75 шт., приурочены они в основном к нижним слоям и относятся как к ВВК АКИО, так могут быть связаны и с носителями керамики с рамчатым декором «одоевского типа».

Предметы из камня в коллекциях из памятников ВВК АКИО из бассейна р. Вятки (Аргыжское, Ройский Шихан, Буйское, Грехневское I), так же многочисленны, отсутствуют они только на поздних городищах (Скорняковское и Кривоборское) (Митряков, Черных, 2014, с. 182-183).

Подавляющее большинство находок из камня в коллекции Одоевского городища составляют кремневые отщепы различных очертаний и пропорций, некоторые из них со следами дополнительной обработки (рис. 16: 2-37). Цветовая гамма камней многообразна - розовые, серые, темно-серые, красные, коричневые, черные. У части предметов на поверхности сохраняется корка окремнелого известняка меньшей твердости. Находится в коллекции и одна заготовка кремневого наконечника стрелы листовидной формы с намеченным черешком (рис. 16: 38).

Три обломка круглых камней со сверлиной по центру найдены во втором слое Одоевского городища (рис. 16: 39-40). Такие предметы из камня хорошо известны на памятниках ананьинского круга и интерпретируются как пряслица или напрясла (Бадер, 1951a, с. 125; Збруева, 1952, с. 63; Халиков, 1977, с. 154;
Патрушев, 1992, с. 74; 2011, с. 30-31; Ашихмина, 2014, рис. 62: 7).

Следующая категория предметов из камня представлена терочными камнями с плоской заполированной рабочей частью (рис. 16: 41) и абразивами в обломках, в виде брусковидных изделий (рис. 16: 42-45). Подобные предметы из камня на памятниках АКИО встречаются с раннеананьинского времени (Халиков, 1977, с. 156-157; Патрушев, Халиков, 1982; Патрушев, 1984, с. 101, 103-105; 2011, с. 31). Важное значение имели они и в комплексах из камня V-III вв. до н. э. на Дьяковом городище (Кренке, 2019, с. 53).

Из кремневых орудий стоит отметить концевой скребок на отщепе красно-коричнево-серых оттенков. Рабочая часть изделия практически прямая, боковые грани также дополнительно обработаны со стороны спинки, спинка высокая, брюшко плоское. Размеры 2,8×2,4-1,2, расширяется к рабочей части (рис. 16: 1).

В завершение обзора материалов, анализ которых продемонстрировал сложную хронологическую структуру и культурное своеобразие памятника, важно отметить необходимость расширения источниковой базы, крайне актуально проведение новых полевых работ на Одоевском городище и синхронных поселениях региона. Стратиграфическая позиция целого ряда комплексов требует уточнения.

Главные выводы, которые можно сделать на основании анализа материалов, полученных на Одоевском городище в 1925-1926 гг. Б.С. Жуковым и О.Н. Бадером, сводятся к следующему.

Изученные материалы позволили подтвердить ранее сделанные наблюдения о памятнике как о крупном поселении АКИО (Бадер, 1951a), а также скорректировать продолжительность его существования. Общий набор признаков и их сопоставление позволяют относить Одоевское городище к кругу памятников вятско-ветлужской культуры АКИО.

Керамические комплексы из Одоевского городища обладают и специфическими чертами, позволяющими установить некоторые их отличия от вятской посуды. Особенности керамики определяются смешением традиций при взаимодействии и развитии культур внутри ананьинского мира в Поветлужье и внешнем культурном влиянии (носителей сетчатой керамики).

Начало функционирования городища в ананьинский период можно определить VII 
вв. до н. э., завершение - III/II вв. до н. э. Основные комплексы вещей связываются со средним и поздним периодом развития АКИО. Изменения, произошедшие при орнаментации ананьинской керамики вятско-ветлужской культуры, выраженные в обеднении мотивов в поздний период, отметить нужно, несмотря на сложность такого определения.

Зафиксирована еще одна важная деталь: ананьинское заселение площадки городища происходит на ранее обжитое место. Предананьинский культурно-хронологический пласт представлен керамикой «одоевского типа» с рамчатым декором. Формирование керамики этого типа на памятнике, вероятно, начинается в конце II - на рубеже II-I тыс. до н. э., основное развитие соотносится с первой четвертью I тыс. до н. э. Появляется и немногочисленная группа гибридной керамики с признаками рамчатой «одоевского типа» и лебяжской. Не исключается бытование комплексов керамики с рамчатым декором и в первой половине VII в. до н. э.

Появление носителей сетчатой керамики на памятнике происходит в третьей четверти I тыс. до н. э., в позднеаньинский период.

\section{ЛИТЕРАТУРА}

Архипов Г.А. Ананьинские городища на р. Вятке // Труды МАЭ. Т. ІІ / Отв. ред. Г.А. Архипов. Йошкар-Ола: Мар. кн. изд-во, 1962. С. 188-205.

Архипов Г.А., Патрушев В.С. Ардинское городище // Поселения и жилища Марийского края / АЭМК. Вып. 6 / Науч. ред. Г.А. Архипов, Г.А. Сепеев. Йошкар-Ола: МарНИИЯЛИ, 1982. С. 51-82.

Ашихмина Л.И. Генезис ананьинской культуры в Среднем Прикамье (по материалам керамики и жилищ) / Археология Евразийских степей. Вып. 19. Казань: ИА АН РТ; Отечество, 2014. 300 с.

Ашихмина Л.И., Черных Е.M., Шаталов В.А. Вятский край на пороге железного века: костяной инвентарь ананьинской эпохи (І тыс. до н.э.) / МИКВАЭ. Т. 12. Ижевск: УдмГУ, 2006. 220 с.

Бадер О.Н. Городища Ветлуги и Унжи // МИА. №22 / Отв. ред. В.Н. Чернецов. М.: АН СССР, 1951. C. $110-158$.

Бадер О.Н. Древнее Поветлужье в связи с вопросами этногенеза Мари и ранней истории Поволжья // СЭ. 1951 б. №2. С. 15-41.

Буров Г.М. О нижнем хронологическом пределе лебяжской культуры // СА. 1983. №2. С. 34-50.

Воеводский М.В. Краткая характеристика керамики городищ Ветлуги и Унжи // МИА. №22 / Отв. ред. В.Н. Чернецов. М.: АН СССР, 1951. С. 159-180.

Гаврилова И.В. Об особенностях памятников волосовского типа в костромском Поволжье // КСИА. №161. М.: Наука, 1980. С. 52-56.

Гадзяикая О.С. Фатьяновский компонент в культуре поздней бронзы (Волго-Камское междуречье) // CA. 1992. № 1. C. 122-141.

Гадзячкая О.С., Уткин А.В. Новые раскопки Вашутинской стоянки // СА. 1989. №1. С. 125-143.

Горюнова Е.И. Этническая история Волго-Окского междуречья / МИА. № 94. М.: Наука, 1961. 264 с.

Гурина Н.Н. Памятники эпохи бронзы и раннего железа в Костромском Поволжье (по материалам Горьковской экспедиции) // МИА. № 110. М.; Л.: АН СССР, 1963. С. 85-203.

Ефремова Д.Ю., Соловьев Б.С. Сиухинское поселение (предварительные итоги исследований 2009-2011 гг.) // Ананьинский мир: истоки, развитие, связи, исторические судьбы / Археология Евразийских степей. Вып. 20 / Отв. ред. С.В. Кузьминых, А.А. Чижевский. Казань: ИА АН РТ, 2014. C. 225-240.

Жуков Б.С., Бадер О.Н. О раскопках Одоевского городища окола села Одоевского, Ветлужского уезда бывш. Нижегородской губернии в 1925-1926 гг. // Приложение к ГОМ 4008-4010. ГБУК Нижегородской области «Нижегородский государственный историко-архитектурный музей-заповедник».

Жульников А.М. Поселения эпохи раннего металла Юго-Западного Прибеломорья. Петрозаводск: Паритет, 2005. $310 \mathrm{c}$.

Збруева А.В. История населения Прикамья в ананьинскую эпоху / Материалы и исследования по археологии Урала и Приуралья. Т. V / МИА. № 30. М.: Изд-во АН СССР, 1952. 326 с.

Комаров К.И. Археологическая карта России. Костромская область / Отв. ред. Ю.А. Краснов. М.: «Восточная литература» РАН, 1999. 368 с.

Коренюк С.Н., Мельничук А.Ф., Черных Е.M. Человеческие жертвоприношения на ананьинских поселениях (кон. VI-III вв. до н. э.) Нижнего и Среднего Прикамья // Археология Евразийских степей. 2017. №4. C. 143-164.

Косменко М.Г. Археологические культуры периода бронзы - железного века в Карелии. СПб.: Наука, 1993. 215 c.

Косменко М.Г. Культура лууконсари // Археология Карелии / Отв. ред. М.Г. Косменко, С.И. Кочкуркина. Петрозаводск: ИЯЛИ КарНЦ РАН. 1996. С. 238-253. 
Крайнов Д.А. Волосовская культура // Эпоха бронзы лесной полосы СССР / Отв. ред. О.Н. Бадер, Д.А. Крайнов, М.Ф. Косарев. М.: Наука, 1987. С. 10-28.

Кренке Н.А. Дьяково городище: культура населения бассейна Москвы-реки в I тыс. до н. э. - I тыс. н. э. М.,: ИА РАН, 2011. 548 с.

Кренке Н.А. Древности бассейна Москвы-реки от неолита до средневековья: этапы культурного развития, формирование производящей экономики и антропогенного ландшафта. М.; Смоленск: Свиток, 2019. 392 с.: 225 илл.

Кузьминых C.B. Об ананьинской обработке бронзы // Из истории культуры волосовских и ананьинских племен / АЭМК. Вып. 2 / Отв. ред. Г.А. Архипов. Йошкар-Ола: Мар НИИ, 1977. С. 126-166.

Кузьминых С.В. Металлургия Волго-Камья в раннем железном веке (медь и бронза). М.: Наука, 1983. $257 \mathrm{c}$.

Кузьминых С.В., Чижевский А.А. Ананьинский мир: взгляд на современное состояние проблемы // У истоков археологии Волго-Камья (к 150-летию открытия Ананьинского могильника) / Ред. С.В. Кузьминых, А.А. Чижевский / Археология евразийских степей. Вып. 8. Елабуга: ИИ АН РТ, 2009. С. $29-55$.

Кузьминых C.B., Чижевский А.А. Хронология раннего периода ананьинской культурно-исторической области // Поволжская археология. 2014. № 3(9). С. 101-137.

Кузьминых С.В., Чижевский А.А. Введение в археологию ананьинской культурно-исторической области: Северо-Восток Европы в финале бронзового и раннем железном веках // Археология Евразийских степей. 2017. №3. С. 22-36.

Лавенто М. Новые АМС-датировки текстильной керамики Среднего и Верхнего Поволжья // Тверской археологический сборник. Вып. 8. Т. I / Отв. ред. И.Н. Черных. Тверь: Триада, 2011. С. 263-272.

Лыганов А.В., Морозов В.В., Азаров Е.С. Луговские I и II стоянки и проблема соотношения черкаскульской, луговской и межовской культур в Нижнем Прикамье // Археология Евразийских степей. 2019. №2. С. 38-98.

Макаров Н.А. Лепная керамика поселения Крутик // Голубева Л.А., Кочкуркина С.И. Белозерская весь (по материалам поселения Крутик IX-X вв.). Петрозаводск: ИЯЛИ КарНЦ РАН, 1991. С. 129-165

Манюхин И.С. Позднекаргопольская культура // Археология Карелии / Отв. ред. М.Г. Косменко, С.И. Кочкуркина. Петрозаводск: ИЯЛИ КарНЦ РАН. 1996. С. 220-238.

Манюхин И.С. Этногенез саамов (опыт комплексного исследования). Автореф. дисс... докт. ист. наук. Ижевск: 2005. 38 с.

Марков В.Н. Об особенностях юго-западных памятников ананьинской общности // Древние этнические процессы Волго-Камья / АЭМК. Вып. 9/ Науч. ред. Г.А. Архипов. Йошкар-Ола, 1985. С. $38-56$.

Марков В.Н. О происхождении и культурной принадлежности вятских городищ ананьинского времени // Памятники первобытной эпохи в Волго-Камье. / Отв. ред. П.Н. Старостин. Казань: ИЯЛИ КФАН СССР, 1988. С. 92-113.

Марков В.Н. Нижнее Прикамье в ананьинскую эпоху (Об этнокультурных компонентах ананьинской общности) / Археология евразийских степей. Вып. 4. Казань: ИИ АН РТ, 2007. 136 с.

Медникова М.Б. После Брока. Трепанации эпохи неолита из коллекции Прюньера в Музее Человека. М.: ИА РАН, 2018. 209 c.

Митряков A.E., Черных E.M. Вятские древности начала железного века: полтора столетия после открытия культуры «костеносных городищ» // Ананьинский мир: истоки, развитие, связи, исторические судьбы / Археология Евразийских степей. Вып. 20 / Отв. ред. С.В. Кузьминых, А.А. Чижевский. Казань: ИА АН РТ, 2014. С. 147-186.

Михеев A.B. Ананьинский горизонт Ардинского городища // Археология Евразийских степей. 2017. №4. C. 33-43.

Мокрушин В.П. Раннегляденовское поселение у д. Севастьяны близ г. Перми // Проблемы финноугорской археологии Урала и Поволжья / Отв. ред. Э.А. Савельева. Сыктывкар: КНЦ УрО РАН, 1992. C. 106-111.

Никитин В.B. На грани эпохи камня и металла. Средневолжский вариант волосовской культурно-исторической общности / Материалы и исследования по археологии Поволжья и Урала. Вып. 10. Йошкар-Ола: МарГУ, 2017. 765 с.

Никитин В.В, Соловьев Б.С. Сомовское II городище // Древности Поволжья и Прикамья / АЭМК. Вып. 25 / Ред. В.В. Никитин, Б.С. Соловьев. Йошкар-Ола: МарНИИ, 2001. С. 4-41.

Николаенко Т.Д. Археологическая карта России. Нижегородская область. Ч. 3. М.: ИА РАН, 2013. $405 \mathrm{c}$.

Николаенко Т.Д. Памятники ананьинской культуры на территории Нижегородской области // Культурный слой Вып. 4. / Отв. ред. Е.А. Молев. Н. Новгород: Нижегородский ун-т, 2016. С. 60-65.

Новиков А.B. Археологические исследования Федоровского поселения в Чухломском районе Костромской области в 2005-2006 гг. // Тверской археологический сборник. Вып. 8. Т. І / Отв. ред. И.Н. Черных. Тверь: Триада, 2011. С. 102-114. 
Новиков А.В. Керамический комплекс поселения Ватажка (по материалам раскопок В.И. Смирнова 1925-1927 гг.) // Тверской археологический сборник. Вып. 10 / Отв. ред. И.Н. Черных Тверь: ТГОМ, 2015. C. $69-86$

Новиков А.В. Поселения РЖВ Костромского Поволжья: (к вопросу об ареале ананьинской культурно-исторической области) // Археология Евразийских степей. 2017. №4. С. 49-69.

Новиков A.B. Поселения с гребенчато-шнуровой и шнуровой керамикой раннего железного века Костромского Поволжья / Археология Евразийских степей. 2018. №2. 288 с.

Новиков А.В. Актуальные проблемы изучения поселений РЖВ восточной части бассейна Верхней Волги (Костромское и Ивановское Поволжье). К постановке вопросов // Археология Евразийских степей. 2019. №2. С. 179-200.

Новиков А.В. К вопросу о развитии сетчатых керамических традиций в поздний период эпохи бронзы - раннем железном веке в окрестностях Галичского озера (по материалам городища Брюхово) // Археология Евразийских степей. 2020. №2. С. 329-368.

Новикова О.В. Археологическое обследование окрестностей Галичского озера в 2019 г. // Культурное наследие Галичской земли / отв. ред. А.В. Новиков. Кострома: Стандарт Принт, 2020. С. 26-33.

Оруджов Э.И. Керамический комплекс Кривоборского городища // Археология Евразийских степей. 2017a. №4. С. 89-104.

Оруджов Э.И. Система расселения носителей ананьинской культурно-исторической области в бассейне рек Вятка и Ветлуга // Поволжская археология. 2017б. №3. С. 117-140.

Оруджсв Э.И. Особенности материальной культуры ананьинской культуры гребенчато-шнуровой керамики басейнов рек Вятка и Ветлуга // Поволжская археология. 2018. №3 (25). С. 288-298.

Оруджов Э.И., Глушков К.Н. Чижевское (Марьин Кокошник) городище. Итоги археологических исследований за 2017-2018 гг. // Археология Евразийских степей. 2019. №2. С. 246-258.

Ошибкина С.В. Об изображении птиц на керамике эпохи бронзы в восточном Прионежье // КСИА. 1980. №161. C. 46-51.

Патрушев В.С. Марийский край в VII-VI вв. до н. э. Йошкар-Ола: Мар. кн. изд-во, 1984. 230 с.

Патрушев В.С. У истоков волжских финнов. Йошкар-Ола: Марийское книжное издательство, 1989. $120 \mathrm{c}$.

Патрушев В.С. Финно-угры России. Йошкар-Ола: Мар. кн. изд-во, 1992. 216 с.

Патрушев В.С. Могильники Волго-Камья раннеананьинского времени / Археология Поволжья и Урала: материалы и исследования. Вып. 2. Казань: Фолиант, 2011. 276 с.

Патрушев В.C. «Текстильная керамика эпохи раннего железа на Ардинском городище // Вестник Пермского университета. 2017а. Вып. 1(36). С. 63-73.

Патрушев В.С. Ананьинские древности Марийского края (по материалам поселений) // Археология Евразийских степей. 2017б. №4. С. 105-126.

Патрушев В.С., Халиков А.Х. Волжские ананьинцы (Старший Ахмыловский могильник). М.: Наука, 1982. $277 \mathrm{c}$.

Петренко А.Г. Становление и развитие основ животноводческой деятельности в истории народов Среднего Поволжья и Приуралья (по археозоологическим материалам) / Археология евразийских степей. Вып. 3. Казань: Ин-т истории АН РТ, 2007. 144 с.

Пудеев А.А. Памятники эпохи бронзы, раннего железного века и раннего Средневековья на территории Варнавинского района Нижегородской области // Нижегородский музей. Человек. Культура. Общество. 2010. №20. С. 86-89

Рождественский А.Н. Краткие сведения о раскопках в Костромской губернии (к IV областному Историко-Археологическому съезду). Кострома: Губ. тип., 1909. 17 с.

Сидоров B.В. Волосовская культура во II тысячелетии до н.э. // Тверской археологический сборник. Вып. 5 / Отв. ред. И.Н. Черных. Тверь: ТГОМ,, 2002. С. 322-331.

Смирнов А.П. Очерки древней и средневековой истории народов Среднего Поволжья и Прикамья // МИА. № 28. М., Л.: Изд-во АН СССР, 1952. 274 с.

Смирнов А.П. Железный век Чувашского Поволжья / МИА. № 95. М.: АН СССР, 1961. 171 с.

Смирнов К.А. Дьяковская культура (материальная культура городищ междуречья Оки и Волги) // Дьяковская культура. М.: Наука, 1974. С. 7-89.

Смольянинов Р.В., Скоробогатов А.М., Бессуднов А.Н., Ивашов М.В., Свиридов А.А. Материалы ивановобугорской культуры в Донской лесостепи // Тверской археологический сборник. Вып. 9. / Отв. ред. И.Н. Черных. Тверь: Триада, 2013. С. 279-294.

Ставиикий В.В., Королев А.И. Энеолит. Ставиџкий В.В. Бронзовый век. // Археология Мордовского края: Каменный век, эпоха бронзы / ред. В.В. Ставицкий, В.Н. Шитов. Саранск: НИИ гум. наук при Правительстве Республики Мордовия, 2008. С. 107-133.

Ставиикий B.B. Бронзовый век. // Археология Мордовского края: Каменный век, эпоха бронзы / ред. В.В. Ставицкий, В.Н. Шитов. Саранск: НИИ гум. наук при Правительстве Республики Мордовия, 2008. С. 134-209. 
Стоколос В.С. Энеолит и бронзовый век // Археология Республики Коми Ч. 4. / Отв. ред. Э.А. Савельева. М.: ДиК, 1997. С. 213-313.

Столяр А.Д., Хлобыстин Л.П. Городище у дер. Серюпитино // МИА. № 110. М.-Л.: Изд-во АН CCCP, 1963. С. 227-238.

Стоянов B.E. Отчет об исследованиях Богородского городища на р. Ветлуге в 1958 г. // Отчет о полевых работах Марийской археологической экспедиции за 1958 г. Казань - Йошкар-Ола, 1959 / НФ МАРТ ИА АН РТ. Ф. 1. Оп.1. №1.

Сулержицикй Л.Д., Фоломеев Б.А. Радиоуглеродная хронология памятников с текстильной керамикой бассейна Средней Оки // Финно-угры России. Памятники с ниточно-рябчатой керамикой. Вып. 1 / Отв. ред. В.С. Патрушев. Йошкар-Ола: МарГУ, 1993. С. 20-34.

Фоломеев Б.А. Типология текстильных отпечатков и хронологическое распространение отдельных видов сетчатых фактур. Дополнения из черновиков // Археология Евразийских степей. 2017. №4. С. 319-335.

Формозов А.Н. Материалы к истории фауны Приветлужья // МИА. №22 / Отв. ред. В.Н. Чернецов. M.: AH CCCP, 1951. С. 181-191.

Халиков А.Х. Очерки истории населения Марийского края в эпоху железа / Железный век Марийского края. Труды МарАЭ. Т. ІІ. Йошкар-Ола: марийское книжное издательство, 1962. 268 с.

Халиков А.X. Волго-Камье в начале эпохи раннего железа (VIII-VI вв. до н. э.). М.: Наука, 1977. 264 с.

Халиков А.Х., Безухова Е.А. Материалы к древней истории Поветлужья (археологические исследования в Ветлужском районе Горьковской области в 1957 году). Горький, 1960. 60 с.

Цветкова И.К. Стоянка Володары (По материалам раскопок 1946 г.) // КСИИМК. Вып. ХХ. М-Л.: Изд-во АН СССР, 1948. С. 3-14.

Челяпов В.П. Памятники примокшанской культуры на Средней Оке // Тверской археологический сборник. Вып. 5 / Отв. ред. И.Н. Черных. Тверь: ТГОМ, 2002. С. 378-387.

Челяпов В.П., Иванов Д.А. Комплекс энеолитической керамики с поселения Лебяжий Бор 6 // Тверской археологический сборник. Вып. 7 / Отв. ред. И.Н. Черных. Тверь: ТГОМ, 2009. С. 249-256.

Черных E.M., Ванчиков В.В., Шаталов В.А. Аргыжское городище на реке Вятке. М.: Ин-т компьютер. исследований, 2002. 188 с.

Чижевский А.А. Погребальные памятники населения Волго-Камья в финале бронзового - раннем железном веках (предананьинская и ананьинская культурно-исторические области) // Археология евразийских степей. Вып. 5. Казань: Школа, 2008. 172 с.

Чижевский А.А. Памятники позднего периода ананьинской культурно-исторической области // Археология Евразийских степей. 2017. №4. С. 196-256.

Чижевский А.А., Галимова М.Ш., Губайдуллина А.В. Казанская стоянка (по материалам исследований 1938 г.) // Археология Евразийских степей. 2019. №2. С. 124-164.

Чижевский А.А. Оруджов Э.И. Вятско-ветлужская археологическая культура (гребенчато-шнуровой керамики) ананьинской культурно-исторической области// Поволжская археология. 2021. № 1(35). C. 8-22.

Чижевский А.А., Хисяметдинова А.А. Оборонительные сооружения мысовых городищ Волго-Камья в раннем железном веке и раннем средневековье // Археология Евразийских степей. 2020. №2 С. С- 277.

Чижевский А.А., Черных Е.М., Хисяметдинова А.А., Митряков А.Е, Спиридонова Е.А., Кочанова М.Д., Алешинская А.С. Скорняковское городище на Вятке / Археология Евразийских степей. Вып. 22. Казань: Казанская недвижимость, 2016. 156 с.

\section{Информация об авторе:}

Новиков Александр Викторович, кандидат исторических наук, заместитель генерального директора ООО «Костромская археологическая экспедиция» (г. Кострома, Россия); кае44@mail.ru , novikovkostroma@mail.ru

\section{REFERENCES}

Arkhipov, G. A. 1962. In Arkhipov, G. A. (ed.). Trudy Mariiskoi arkheologicheskoi ekspeditsii (Proceedings of Mari Archaeological Expedition) II. Yoshkar-Ola: "Mariiskoe knizhnoe izdatel'stvo" Publ., 188-205 (in Russian).

Arkhipov, G. A., Patrushev, V. S. 1982. In Arkhipov, G. A., Sepeev, G. A. (eds.). Poseleniia i zhilishcha Mariiskogo kraia (Settlements and Dwellings of the Mari Land). Series: Arkheologiia i etnografia Mariiskogo kraia (Archaeology and Ethnography of the Mari Land) 6. Yoshkar-Ola: Mari Research Institute of Language, Literature, and History, 51-82 (in Russian).

Ashikhmina, L. I. 2014. Genezis anan'inskoi kul'tury v Srednem Prikam'e (po materialam keramiki $i$ zhilishch) (Genesis of the Ananyino Culture in the Middle Kama Area (According to the Ceramics and Dwellings)). Series: Arkheologiia evraziiskikh stepei (Archaeology of the Eurasian Steppes) 19. Kazan: Institute of Archaeology named after A. Kh. Khalikov, Tatarstan Academy of Sciences; "Otechestvo" Publ. (in Russian). 
Ashikhmina, L. I., Chernykh, E. M., Shatalov, V. A. 2006. Vyatskiy kray na poroge zheleznogo veka: kostyanoy inventar' anan'inskoy epokhi (I tys. do n.e.) (Vyatka Region on the Threshold of the Iron Age: Bone Inventory of Ananyino Period ( $1^{\text {st }}$ Millennium B.C.)). Series: Materialy i issledovaniia Kamsko-Viatskoi arkheologicheskoi ekspeditsii (Proceedings and Research of the Kama-Vyatka Archaeological Expedition) 12. Izhevsk: Udmurt State University (in Russian).

Bader, O. N. 1951. In Chernetsov, V. N. (ed.). Materialy $i$ issledovaniia po arkheologii (Materials and Research in Archaeology) 22. Moscow: Academy of Sciences of the USSR, 110-158 (in Russian).

Bader, O. N. 1951b. In Sovetskaia etnografiia (Soviet Ethnography) (2), 15-41. (in Russian).

Burov, G. M. 1983. In Sovetskaya arkheologiya (Soviet archeology). (2). 34-50 (in Russian).

Voevodskii, M. V. 1951. In Chernetsov, V. N. (ed.). Materialy $i$ issledovaniia po arkheologii (Materials and Research in Archaeology) 22. Moscow: Academy of Sciences of the USSR, 159-180. (in Russian).

Gavrilova, I. V. 1980. In Kratkie soobshcheniia Instituta arkheologii (Brief Communications of the Institute of Archaeology) 161. Moscow: "Nauka" Publ., 52-56. (in Russian).

Gadzhyatskaya, O. S. 1992. In Sovetskaya arkheologiya (Soviet archeology). (1). 122-141 (in Russian).

Gadzhyatskaya, O. S., Utkin, A. V. 1989. In Sovetskaya arkheologiya (Soviet archeology). (1). 125-143 (in Russian).

Goriunova, E. I. 1961. Etnicheskaia istoriia Volgo-Okskogo mezhdurech'ia (Ethnic History of the VolgaOka Area). Series: Materialy i issledovaniia po arkheologii SSSR (Materials and Research in the USSR Archaeology) 94. Moscow: "Nauka" Publ. (in Russian).

Gurina, N. N. 1963. In Materialy i issledovaniia po arkheologii SSSR (Materials and Research in the USSR Archaeology) 110. Moscow; Leningrad: the USSR Academy of Sciences, 85-203. (in Russian).

Efremov, D. Yu., Soloviev, B. S. 2014. In Kuzminykh, S. V., Chizhevsky, A. A. (eds.). Anan'inskii mir: istoki, razvitie, sviazi, istoricheskie sud'by (The World of Ananyino: Origins, Evolution, Relations, Historical Fate). Series: Arkheologiia Evraziiskikh stepei (Archaeology of Eurasian Steppes) 20. Kazan: "Otechestvo" Publ., 225-240 (in Russian).

Zhukov, B. S., Bader, O. N. 1925-1926. In Prilozhenie k GOM 4008-4010. GBUK Nizhegorodskoi oblasti «Nizhegorodskii gosudarstvennyi istoriko-arkhitekturnyi muzei-zapovednik» (Appendix to GOM 4008-4010. State Budgetary Institution of Culture of Nizhny Novgorod Oblast "Nizhny Novgorod State Historical and Architectural Museum-Reserve") (in Russian).

Zhul'nikov, A. M. 2005. Poseleniia epokhi rannego metalla Iugo-Zapadnogo Pribelomor'ia (Settlements of the Early Metal Age of the South-Western White Sea Region). Petrozavodsk: "Paritet" Publ. (in Russian).

Zbrueva, A. V. 1952. Istoriia naseleniia Prikam 'ia v anan'inskuiu epokhu (History of the Population of the Kama River Region in the Ananyino Time). Series: Materialy i issledovaniia po arkheologii Urala i Priural'ia (Materials and Research on the Archaeology of Ural and the Cis-Urals Area) V. Materialy i issledovaniia po arkheologii SSSR (Materials and Research in the USSR Archaeology) 30. Moscow: Academy of Sciences of the USSR (in Russian).

Krasnov, Yu. A. (ed.). 1999. Arkheologicheskaia karta Rossii. Kostromskaia oblast' (Archaeological Map of Russia: Kostroma Oblast). Moscow: "Vostochnaia Literatura" Publ., Russian Academy of Sciences (in Russian).

Korenyuk, S. N., Melnichuk, A. F., Chernykh, E. M. 2017. In Arkheologiia Evraziiskikh stepei (Archaeology of Eurasian Steppes) 4, 143-164 (in Russian).

Kosmenko, M. G. 1993. Arkheologicheskie kul'tury perioda bronzy - zheleznogo veka v Karelii (The archaeological cultures of the period of the Bronze-Iron Ages in Karelia). Saint Petersburg: "Nauka" Publ. (in Russian).

Kosmenko, M. G. 1996. In Kosmenko, M. G., Kochkurina, S. I. (eds.). Arkheologiia Karelii (Archaeology of the Karelia). Petrozavodsk: Karelian Research Center RAS Publ., 238-253 (in Russian).

Krainov, D. A. 1987. In Bader, O. N., Krainov, D. A., Kosarev, M. F. (eds.). Epokha bronzy lesnoi polosy SSSR (The Bronze Age in the Forest Zone of the USSR). Series: Archaeology of the USSR. Moscow: "Nauka" Publ., 10-28 (in Russian).

Krenke N. A. 2011. Diakovo gorodishche: kultura naseleniya basseyna Moskvy-reki v I tys. do n. e. - I tys. n. e. (Dyakovo Hillfort: culture of the population of the Moscow River basin in the $1^{\text {st }}$ Millennium BC $-1^{\text {st }}$ Millennium BC). Moscow: Institute of Archaeology, Russian Academy of Sciences (in Russian).

Krenke, N. A. 2019. Drevnosti basseyna Moskvy-reki ot neolita do srednevekov'ya: etapy kul'turnogo razvitiya, formirovanie proizvodyashchey ekonomiki $i$ antropogennogo landshafta (Archaeology of Moskva River Basin from the Neolithic to the Middle Ages). Moscow; Smolensk: "Svitok" Publ. (in Russian).

Kuzminykh, S. V. 1977. In Arkhipov, G. A. (ed.). Iz istorii kul'tury volosovskikh i anan'inskikh plemen (History of the Culture of Ananyino and Volosovo Tribes). Series: Arkheologiia i etnografiia Mariiskogo kraia (Archaeology and Ethnography of the Mari Land) 2. Yoshkar-Ola: Mari Research Institute of Language, Literature, and History, 126-166 (in Russian).

Kuzminykh, S. V. 1983. Metallurgiia Volgo-Kam'ia v rannem zheleznom veke (med'i bronza) (Metallurgy of the Volga-Kama Region in the Early Iron Age (Copper and Bronze)). Moscow: "Nauka" Publ. (in Russian). 
Kuzminykh, S. V., Chizhevsky, A. A. 2009. In Kuzminykh, S. V., Chizhevsky, A. A. (eds.). U istokov arkheologii Volgo-Kam'ia (k 150-letiiu otkrytiia Anan'inskogo mogil'nika) (At the Origins of Archaeology of the Volga-Kama Region (on the 150 th Anniversary of Discovery of the Ananyino Burial Ground)). Series: Archaeology of the Eurasian Steppes 8. Yelabuga: Institute of History named after Sh. Mardzhani, Tatarstan Academy of Sciences, 29-55 (in Russian).

Kuzminykh, S. V., Chizhevsky, A. A. 2014. In Povolzhskaya arkheologiya (Volga River Region Archaeology) 9 (3), 101-137 (in Russian).

Kuzminykh, S. V., Chizhevsky, A. A. 2017. In Arkheologiia Evraziiskikh stepei (Archaeology of Eurasian Steppes) 3, 22-36 (in Russian).

Lavento, M. 2011. In Chernykh, I. N. (ed.). Tverskoi arkheologicheskii sbornik (Tver Archaeological Collection of Articles) (8). Tver: "Triada", 263-272 (in Russian).

Lyganov, A. V., Morozov, V. V., Azarov, E. S. 2019. In Arkheologiia Evraziiskikh stepei (Archaeology of Eurasian Steppes) 2, 38-98 (in Russian).

Makarov, N. A. 1991. In Golubeva, L. A., Kochkurina, S. I. Belozerskaia ves' (po matialam poseleniia Krutik IX-Xvv.) (The Beloe Ozero Ves'(Based on Materials from Krutik Settlement of the 9th-10th Centuries). Petrozavodsk: Karelian Research Center RAS Publ., 129-165 (in Russian).

Manyukhin, I. S. 1955. Etnogenez saamov (opyt kompleksnogo issledovaniia) (The Ethnogenesis of the Saami (Comprehensive Study Experience). Thesis of Diss. of doctor of of Historical Sciences. Izhevsk (in Russian).

Manyukhin, I. S. 1996. In Kosmenko, M. G., Kochkurina, S. I. (eds.). Arkheologiia Karelii (Archaeology of the Karelia). Petrozavodsk: Karelian Research Center RAS Publ., 220-238 (in Russian).

Markov, V. N. 1985. In Arkhipov, G. A. (ed.). Drevnie etnicheskie protsessy Volgo-Kam 'ia (Ancient Ethnic Processes in the Volga and Kama Rivers Region). Series: Arkheologiia i etnografiia Mariiskogo kraia (Archaeology and Ethnography of Mari Land) 9. Yoshkar-Ola, 38-56 (in Russian).

Markov, V. N. 1988. In Starostin, P. N. (ed.). Pamiatniki pervobytnoi epokhi v Volgo-Kam'e (Sites of the Primeval Period in the Volga-Kama Region). Kazan: Institute for Language, Literature and History of Kazan Branch of the USSR Academy of Scienses, 92-113 (in Russian).

Markov, V. N. 2007. Nizhnee Prikame v ananinskuiu epokhu (The Lower Kama River Region in the Ananyino Epoch). Series: Arkheologiia Evraziiskikh stepei (Archaeology of Eurasian Steppes) 4. Kazan: Institute for History named after Sh. Mardzhani, Tatarstan Academy of Sciences (in Russian).

Mednikova, M. B. 2018. Posle Broka. Treponatsiia epokhi neolita iz kollektsii Priun'era v Muzee Cheloveka (After Brock. Trepanations of the Neolithic Period from the Prunieres Collection at the Museum of Humanity). Moscow: Institute of Archaeology, Russian Academy of Sciences (in Russian).

Mitryakov, A. E., Chernykh, E. M. 2014. In Kuzminykh, S. V., Chizhevsky, A. A. (eds.). Anan 'inskii mir: istoki, razvitie, sviazi, istoricheskie sud'by (The World of Ananyino: Origins, Evolution, Relations, Historical Fate). Series: Arkheologiia Evraziiskikh stepei (Archaeology of Eurasian Steppes) 20. Kazan: "Otechestvo" Publ., 147-186 (in Russian).

Mikheev, A. V. 2017. In Arkheologiia Evraziiskikh stepei (Archaeology of Eurasian Steppes) 4, 33-43 (in Russian).

Mokrushin, V. P. 1992. In Savel'eva, E. A. (ed.). Problemy finno-ugorskoi arkheologii Urala i Povolzh'ia (Issues of the Finno-Ugric Archaeology of the Urals and the Volga Region). Syktyvkar: Komi Research Center, Ural Branch of the Russian Academy of Sciences, 106-111 (in Russian).

Nikitin, V. V. 2017. Na grani epokhi kamnya i metalla. Srednevolzhskiy variant volosovskoy kul'turnoistoricheskoy obshhnosti (Between the Stone and Metal Periods. Middle Volga Variation of the Volosovo Cultural and Historical Community). Series: Arkheologiia Povolzhia i Urala. Materialy i issledovaniia (Volga and the Urals Archaeology. Materials and Studies) 10. Yoshkar-Ola: Mari State University (in Russian).

Nikitin, V. V., Solov'ev, B. S. 2001. In Nikitin, V. V., Solov'ev, B. S. (eds.). Drevnosti Povolzh 'ia I Prikam 'ia (Antiquities of the Volga and Kama Regions). Arkheologiia i etnografiia Mariiskogo kraia (Archaeology and Ethnography of the Mari Land) 25. Yoshkar-Ola: Mari Research Institute of Language, Literature, History and Ethnography Institute, 4-41 (in Russian).

Nikolaenko, T. D. 2013. Arkheologicheskaia karta Rossii. Nizhegorodskaia oblast' (Archaeological Map of Russia. Nizhny Novgorod Region). Part 3. Moscow: Institute of Archaeology, Russian Academy of Sciences (in Russian).

Nikolaenko, T. D. 2016. In Molev, E. A. (ed.). Kul'turnii sloi (Cultural Layer) 4. Nizhny Novgorod: Nizhny Novgorod State University, 60-65 (in Russian).

Novikov, A. V. 2011. In Chernykh, I. N. (ed.). Tverskoi arkheologicheskii sbornik (Tver Archaeological Collection of Articles) (8). Tver: "Triada", 102-114 (in Russian).

Novikov, A. V. 2015. In Chernykh, I. N. (ed.). Tverskoi arkheologicheskii sbornik (Tver Archaeological Collection of Articles) 10. Tver: Tver State United Museum, 69-86 (in Russian).

Novikov, A. V. 2017. In Arkheologiia Evraziiskikh stepei (Archaeology of Eurasian Steppes) 4, 49-69 (in Russian). 
Novikov, A. V. 2018. In Arkheologiia Evraziiskikh stepei (Archaeology of Eurasian Steppes) 2 (in Russian). Novikov, A. V. 2019. In Arkheologiia Evraziiskikh stepei (Archaeology of Eurasian Steppes) 2, 179-200

(in Russian).

Novikov, A. V. 2020. In Arkheologiia Evraziiskikh stepei (Archaeology of Eurasian Steppes) 2, 329-368 (in Russian).

Novikova, O. V. 2020. In Novikov, A. V. (ed.). Kul'turnoe nasledie Galichskoi zemli (Cultural Heritage of the Galich Land). Kostroma: "Standart Print" Publ., 26-33 (in Russian).

Orudzhov, E. I. 2017a. In Arkheologiia Evraziiskikh stepei (Archaeology of Eurasian Steppes) 4, 89-104

(in Russian).

Orudzhov, E. I. 2017b. In Povolzhskaya arkheologiya (Volga River Region Archaeology) 21 (3), 117-140 (in Russian).

Orudzhov, E. I. 2018. In Povolzhskaya arkheologiya (Volga River Region Archaeology) 25 (3), 288-298

(in Russian).

Orudzhov, E. I., Glushkov, K. N. 2019. In Arkheologiia Evraziiskikh stepei (Archaeology of Eurasian Steppes) 2, 246-258 (in Russian).

Oshibkina, S. V. 1980. In Kratkie soobshcheniia Instituta arkheologii (Brief Communications of the Institute of Archaeology) 161. Moscow: "Nauka" Publ., 46-51 (in Russian).

Patrushev, V. S. 1984. Mariiskii krai v VII- VI vv. do n.e. (Mari Land in the 7th-6th Centuries BC). Yoshkar-Ola: "Mariiskoe knizhnoe izdatel'stvo" Publ. (in Russian).

Patrushev, V. S. 1989. U istokov volzhskikh finnov (At the Origins of the Volga Finns). Yoshkar-Ola: "Mariiskoe knizhnoe izdatel'stvo" Publ. (in Russian).

Patrushev, V. S. 1992. Finno-ugry Rossii (The Finno-Ugric Peoples of Russia). Yoshkar-Ola: "Mariiskoe knizhnoe izdatel'stvo" Publ. (in Russian).

Patrushev, V. S. 2011. Mogil'niki Volgo-Kam 'ia ranneanan 'inskogo vremeni (Burial Grounds of the VolgaKama Region of the Early Ananyino Period). Series: Arkheologiia Povolzhia i Urala. Materialy i issledovaniia (Volga and the Urals Archaeology. Materials and Studies) 2. Kazan: "Foliant" Publ. (in Russian).

Patrushev, V. S., Khalikov, A. Kh. 1982. Volzhskie anan 'intsy (Starshii Akhmylovskii mogil'nik) (The Volga Ananyino People (The Elder Akhmylovo Burial Ground)). Moscow: "Nauka" Publ. (in Russian).

Patrushev, V. S. 2017. In Vestnik Permskogo universiteta. Seriia «Istoriia» (Bulletin of the Perm University. History Series) 36 (1), 63-73. (in Russian).

Patrushev, V. S. 2017b. In Arkheologiia Evraziiskikh stepei (Archaeology of Eurasian Steppes) 4, 105-126. (in Russian).

Petrenko, A. G. 2007. Stanovlenie i razvitie osnov zhivotnovodcheskoi deiatel'nosti v istorii Srednego Povolzh'ia i Priural'ia (po arkheozoologicheskim materialam) (Establishment and development of the foundations of cattle breeding in the history of peoples from the Middle Volga region and Pre-Urals (on the basis of archaeological materials). Series: Arkheologiia Evraziiskikh stepei (Archaeology of the Eurasian Steppes) 3. Kazan: Institute of History, Academy of Sciences of the Republic of Tatarstan (in Russian)

Pudeev, A. A. 2010. In Nizhegorodskii muzei. Chelovek. Kul'tura. Obshchestvo (Nizhny Novgorod Museum. Man. Culture. Society) (20), 86-89 (in Russian).

Rozhdestvenskii, A. N. 1909. Kratkie svedeniia o raskopkakh v Kostromskoi gubernii (k IV oblastnomu istoriko-arkheologicheskomu sezdu) (Summary of the Excavations in Kostroma Governorate (for the 4th Regional Historical and Archaeological Congress).). Kostroma. (in Russian).

Sidorov, V. V. 2002. In Chernykh, I. N. (ed.). Tverskoi arkheologicheskii sbornik (Tver Archaeological Collection of Articles) 5. Tver: Tver State United Museum, 322-331 (in Russian).

Smirnov, A. P. 1952. In Materialy $i$ issledovaniia po arkheologii SSSR (Materials and Research in the USSR Archaeology) 28. Moscow; Leningrad: Academy of Sciences of the USSR (in Russian).

Smirnov, A. P. 1961. Zheleznyi vek Chuvashskogo Povolzh'ia (Iron Age of the Chuvash Volga Region). Materialy i issledovaniia po arkheologii SSSR (Materials and Studies in the USSR Archaeology) 95. Moscow: Academy of Sciences of the USSR (in Russian).

Smirnov, K. A.1974. Krasnov, Yu. A. (ed.). D'iakonovskaia kul 'tura (Dyakovo Culture). Moscow: "Nauka" Publ., 7-89 (in Russian).

Smol'yaninov, R. V., Skorobogatov, A. M., Bessudnov, A. N., Ivashov, M. V., Sviridov, A. A. 2013. In Chernykh, I. N. (ed.). Tverskoi arkheologicheskii sbornik (Tver Archaeological Collection of Articles) 9. Tver: "Triada" Publ., 322-331 (in Russian).

Stavitskii, V. V. 2008. In Stavitskii, V. V., Shitov, V. N. (eds.). Arkheologiia Mordovskogo kraia: Kamennyi vek, epokha bronzy (Archaeology of the Mordva Land: Stone Age and Bronze Period). Saransk: Research Institute of the Humanities by the Government of the Republic of Mordovia, 134-209 (in Russian).

Stavitskii, V. V., Korovev, A. I. 2008. In Stavitskii, V. V., Shitov, V. N. (eds.). Arkheologiia Mordovskogo kraia: Kamennyi vek, epokha bronzy (Archaeology of the Mordva Land: Stone Age and Bronze Period). Saransk: Research Institute of the Humanities by the Government of the Republic of Mordovia, 107-133 (in Russian). 
Stokolos, V. S. 1997. In Savel'eva, E. A. (ed.). Arkheologiia Respubliki Komi (Archaeology of the Komi Republic) 4. Moscow: "DiK" Publ., 213-313 (in Russian).

Stolyar, A. D., Khlodystin, L. P. 1963. In Materialy i issledovaniia po arkheologii SSSR (Materials and Research in the USSR Archaeology) 110. Moscow; Leningrad: the USSR Academy of Sciences, 227-238. (in Russian).

Stoyanov, V. E. 1959. Otchet o polevykh issledovaniyakh Mariyskoy arkheologicheskoy ekspeditsii za 1958 g. (Report on Field Studies of the Mari Archaeological Expedition in 1958) I. Kazan' - Yoshkar-Ola. Scientific Fund of the Museum of Archaeology of the Republic of Tatarstan, Archaeology Institute named after A. Kh. Khalikov, Academy of Sciences of the Republic of Tatarstan. Fund 1. Inv. 1 (in Russian).

Sulerzhitskii, L. D., Folomeev, B. A. 1993. In Patrushev, V. S. (ed.). Finno-ugry Rossii. Pamyatniki s nitochno-ryabchatoy keramikoy (Finno-Ugric Peoples of Russia. Sites with Thread and Speckle Ceramics) 1. Yoshkar-Ola: Mari State University Publ., 20-34 (in Russian).

Folofeev, B. A. 2017. In Arkheologiia Evraziiskikh stepei (Archaeology of Eurasian Steppes) 4, 319-335 (in Russian).

Formozov, A. N. 1951. In Chernetsov, V. N. (ed.). Materialy i issledovaniia po arkheologii (Materials and Research in Archaeology) 22. Moscow: Academy of Sciences of the USSR, 181-191. (in Russian).

Khalikov, A. Kh. 1962. Ocherki istorii naseleniia Mariiskogo kraia v epokhu zheleza (Essays of History of the Population of the Mari Region in the Iron Age) Zheleznyi vek Mariiskogo kraia (Iron Age of the Mari Region). Series: Proceedings of the Mari Archaeological Expedition II. Yoshkar-Ola: "Mariiskoe knizhnoe izdatel'stvo" Publ. (in Russian).

Khalikov, A. Kh. 1977. Volgo-Kam'e v nachale epokhi rannego zheleza. VIII-VI vv. do n. e. (The VolgaKama Region in the Beginning of the Early Iron Age ( $8^{\text {th }}-6^{\text {th }}$ Centuries $\left.B C\right)$ ). Moscow: "Nauka" Publ. (in Russian).

Khalikov, A. Kh., Bezukhova, E. A. 1960. Materialy k drevnei istorii Povetluzh'ia (arkheologicheskie issledovaniia v Vetluzhskom raione Gor 'kovskoi oblasti v 1957 godu) (Materials on the Ancient History of the Vetluga River Area: Archaeological Investigations in the Vetluga District, Gorky Oblast, in 1957). Gorky (in Russian).

Tsvetkova, I. K. 1948. In Kratkie soobshcheniia Instituta istorii material'noi kul'tury (Brief Communications of the Institute for the History of Material Culture) 20. Moscow: Academy of Sciences of the USSR, 3-14 (in Russian).

Chelyapov, V. P. 2002. In Chernykh, I. N. (ed.). Tverskoi arkheologicheskii sbornik (Tver Archaeological Collection of Articles) 5. Tver: Tver State United Museum, 378-387 (in Russian).

Chelyapov, V. P., Ivanov, D. A. 2009. . In Chernykh, I. N. (ed.). Tverskoi arkheologicheskii sbornik (Tver Archaeological Collection of Articles) 7. Tver: Tver State United Museum, 249-256 (in Russian).

Chernykh, E. M., Vanchikov, V. V., Shatalov, V. A. 2002. Argyzhskoe gorodishche na reke Viatke (Argyzh Hillfort on the Vyatka River). Moscow: Institute of Computer Research (in Russian).

Chizhevsky, A. A. 2008. Pogrebal'nye pamiatniki naseleniia Volgo-Kam'ia v finale bronzovogo - rannem zheleznom vekakh (predanan'inskaia i anan'inskaia kul'turno-istoricheskie oblasti) Burial sites of the population of Volga-Kama in the Final Bronze - Early Iron Ages (pre- Ananyino and Ananyino cultural and historical areals). Series: Archaeology of Eurasian Steppes, 5. Kazan: "Shkola" Publ. (in Russian).

Chizhevsky, A. A. 2017. In Arkheologiia Evraziiskikh stepei (Archaeology of Eurasian Steppes) 4, 196-256 (in Russian).

Chizhevsky, A. A., Galimova, M. Sh., Gubaidullina, A. V. 2019. In Arkheologiia Evraziiskikh stepei (Archaeology of Eurasian Steppes) 2, 124-164 (in Russian).

Chizhevsky, A. A., Orudzhov, E. I. 2021. In Povolzhskaya arkheologiya (Volga River Region Archaeology) 35 (1), 8-22 (in Russian).

Chizhevsky, A. A., Khisyametdinova, A. A. 2020. In Arkheologiia Evraziiskikh stepei (Archaeology of Eurasian Steppes) 2, 8-277 (in Russian).

Chizhevsky A. A., Chernykh E. M., Khisiametdinova A. A., Mitriakov A. E, Spiridonova E. A., Kochanova M. D., Aleshinskaia A. S. 2016. Skorniakovskoe gorodishche na Viatke (Skorniaki hillfort on the Vyatka River). Series: Arkheologiia Evraziiskikh stepei (Archaeology of Eurasian Steppes) 22. Kazan: "Kazanskaia nedvizhimost"' Publ. (in Russian).

\section{About the Author:}

Novikov Aleksandr V. Candidate of Historical Sciences. LLC "Kostroma Archaeological Expedition", 156013, Kostroma, Marshal Novikov, Str. 10, Russian Federation; kae44@mail.ru, novikov-kostroma@mail. ru 
Приложение 1

\title{
ТЕХНИКО-ТЕХНОЛОГИЧЕСКИЙ АНАЛИЗ СОСУДОВ ИЗ ОДОЕВСКОГО ГОРОДИЩА
}

\author{
C2021 г. А.А. Швецова
}

Изучение гончарной технологии осуществлялось в рамках историко-культурного подхода, разработанного А.А. Бобринским и развитого его последователями (Бобринский, 1978; Бобринский, 1999; Цетлин, 2012; Цетлин, 2017). Каждый сосуд рассматривается как результат приложения определенных навыков труда гончара, которые с течением времени оформились в культурные традиции и передавались между поколениями. Методика технико-технологического анализа подразумевает визуальный осмотр свежих изломов фрагментов сосудов и их поверхностей при 20-40-кратном увеличении с использованием бинокулярного стереоскопического микроскопа (для проведения данного исследования применялся микроскоп Микромед MC-2-ZOOM). В процессе осмотра фиксируются особые «следы», возникшие в процессе изготовления сосуда, которые позволяют реконструировать навыки труда гончара. Совокупность полученных сведений делает возможным реконструкцию культурных традиций в гончарстве изучаемого сообщества и их интерпретацию применительно к его историческому развитию.

В структуре гончарного производства выделяется три последовательных стадии: подготовительная, созидательная и закрепительная (Бобринский, 1999). Первая стадия объединяет действия гончара по приготовлению формовочной массы. Она включает в себя отбор и добычу исходного сырья, его обработку и при необходимости добавление в его состав минеральных и органических компонентов. Во вторую стадию объединены действия гончара, направленные на создание сосуда, и в третью стадию - действия, предпринимаемые для придания сосудам прочности и влагонепроницаемости. В рамках данного исследования изучение гончарной технологии осуществлялось применительно к подготовительной стадии гончарного производства.

Технико-технологическое изучение проведено для сосудов различных типов и культурно-хронологических позиций.

Результаты проведенных анализов показали существование среди гончаров городища нескольких гончарных традиций изготовления сосудов. Они различаются свойствами использованного исходного пластичного сырья (ИПС) и видом искусственных примесей, добавленных в состав формовочных масс (ФМ). Исходя из этого выделено 7 различных рецептов ФМ, которые в зависимости от вида искусственно введённых примесей разделены на четыре группы:

\section{Группа І. Глина + раковина моллюсков.}

Наблюдения за качественным и количественным составом естественных примесей в составе ИПС позволяют выделить два источника его добычи:

a) Незапесоченная (условно пластичная) ожелезненная глина (ОГ) (степень ожелезненности определялась после повторного обжига фрагментов от каждого образиа в муфельной печи при $850^{\circ} \mathrm{C}$ ) (рис. к приложению 1: 1, 1:2) - 6 сосудов (рис. 3: 14; 4: 4, 13; 8: $23 ; 9: 25 ; 11: 25)$. В ее составе зафиксированы следующие включения примесей естественного происхождения: квариевый песок крупностью 0,1 мм в концентрации до 10-12 включений на 1 c. $^{2}$ (окатанной и полуокатанной формы; прозрачный и полупрозрачный); квариевый песок крупностью 0,2-0,5 мм в единичной концентрации (окатанной формы, полупрозрачный); конкреции окисей железа двух видов: округлой формьл коричнево-оранжевого и коричневого иветов, рыхлой струкmуры (размер от 0,1 до 0,7 мм; концентрация от единичной до 10-12 включений на $1 \mathrm{~cm}^{2}$ ), а также обломочной или слабоокатанной формы яркого красно-коричневого ивета, невысокой плотности и однородного состава (размер от 0,2 до 1,7 мм; концентрация от единичной до 10-15 включений на $1 \mathrm{~cm}^{2}$ ) (рис. 1: 13, 1: 14); бурый железняк оолитовой формы (величина от 0,5 до 0,7 мм, концентрация единичная); плотныле слабоокатанные комки чистой ожелезненной глинь (размер 0,2-1,2 мм, концентрация единичная) прослежены в одном образце.

б) Среднезапесоченная ОГ (условно среднепластичная) (рис. к приложению 1: $3,1: 4$ ) - 3 сосуда (рис. 9: $18 ; 8: 22 ; 10: 17)$. Содержит следующие естественные примеси: квариевый песок крупностью 0,1-0,2 мм в концен- 
трачии 40-50 включений на 1 cм² $^{2}$ (окатанной и полуокатанной формы; прозрачный и полупрозрачный, изредка серый, светло-коричневый и белесый); квариевый песок крупностью 0,3-0,7 мм в единичной концентрации (окатанной формы, полупрозрачный); песок пылевидной фракиии $(<0,1$ мм) в малой (2 сосуда) и значительной концентрации (1 сосуд); конкрециии окисей железа в виде округльх рыхльхх и более плотных окатанных и полуокатанных включений яркого красно-коричневого (1 сосуд) и коричневого (2 сосуда) извета (величина от 0,1 до 2 мм; концентрация от единичной до 10-15 включений на $\left.1 \mathrm{~cm}^{2}\right)$; плотные слабоокатанные комки чистой ожелезненной глины (размер 0,7-2 мм, концентрация единичная) - прослежены в одном образце.

ИПС было использовано в естественно увлажненном состоянии, следов его предварительного дробления не зафиксировано (свойственно всем выделенным группам сосудов).

В состав ФМ добавлена примесь измельченной раковины моллюсков, которая исходя из набора наблюдаемых признаков, была предварительно термически обработана, а именно - нагрета на углях (рис. 2: 1-6). Среди включений раковины массово присутствуют мельчайшие частицы толщиной 0,1 мм и менее; фрагменты расщепляются на тонкие горизонтальные слои (рис. 2: 1); преобладают фрагменты округлых очертаний (в форме чешуек) (рис. 2: 2-3), наряду с которыми присутст-вует небольшое количество остроугольных частиц, как правило, наибольшей толщины (участки раковины, испытавшие наименьшее воздействие высокой температуры); раковина преимущественно серых оттенков, реже - молочно-белых; фрагменты мягкие (легко разрушаются иглой); встречаются частицы перламутра (Салугина, 2016). Для подготовки примеси использовались раковины двустворок: встречаются фрагменты «столбчатого» слоя и замков (рис. 2: 4-6). Термическая обработка раковин происходила совместно с находившимся в них телом моллюска. Об этом свидетельствуют зафиксированные в изломах фрагментов поры округлой и аморфной формы с черными стенками, внутри которых часто находится углефицированный сгусток - остаток мышечной ткани моллюска (размер пор от 0,1 до 2,5 мм) (рис. 2: 7, 2: 8).

После термического воздействия раковина утрачивала изначальную твердость и разминалась до максимальной величины частиц в 4-5 мм (преимущественная крупность
0,5-1,5 мм). Затем подготовленная раковина совместно с образовавшимися при ее дроблении мельчайшими частицами была добавлена в ФМ. Концентрация частиц размерностью более 0,5 мм составляет около 40-60 включений на $1 \mathrm{~cm}^{2}$.

В одном из фрагментов включения раковины выщелочены, но по характеру сохранившихся пустот можно сделать вывод об ее аналогичной термической подготовке.

Группа II. Глина + раковина моллюска + шамот.

Зафиксировано использование ИПС из двух различных источников:

a) Незапесоченная (условно пластичная) OГ (рис. к приложению 1: 5, 1: 6) - 2 сосуда (рис. 10: 15). Качественный и количественный состав естественных примесей аналогичен описанным выше для ИПС сосудов первой группы.

б) Слабозапесоченная (условно пластичная) $О Г$ - (рис. к приложению 1: 7, 1: 8) 2 сосуда (рис. 10: 6; 12: 28). В отличие от незапесоченного ИПС содержит естественную примесь квариевого песка крупностью 0,1-0,2 мм в концентрачии 20-25 включений на $1 \mathrm{~cm}^{2}$ (окатанной и полуокатанной формы; прозрачный и полупрозрачный, изредка белесый), квариевого песка крупностью 0,3-0,5 мм в концентрации до 10 включений на $1 \mathrm{~cm}^{2}$ (окатанной формы, полупрозрачный) и песок пылевидной фракиии (<0,1 мм) в малой концентрации. Также встречаются включения конкреций окисей железа.

Раковины моллюсков, добавленные в состав $Ф М$, как и в случае с сосудами первой группы, были предварительно термически обработаны (нагреты на углях) и имеют аналогичный описанному выше набор внешних признаков.

Шамот изготавливался путем дробления старых вышедших из употребления сосудов до крупности 0,7-5 мм и, очевидно, предварительно просеивался (практически отсутствуют мельчайшие частицы величиной менее 0,5 мм) (рис. 2: 12). Концентрация от единичной до 1:7-1:8. Примечательно, что для изготовления шамота в одном случае были использованы сосуды, ФМ которых содержали примесь измельченной раковины моллюсков (рис. 10: 6).

Группа III. Глина + шамот + органическая добавка (предположительно выжимка из навоза) (рис. 9: 4).

Сосуд изготовлен из незапесоченной (условно пластичной) $О Г$, близкой по составу естественных примесей описанным выше 
незапесоченным глинам (рис. к приложению 1:9, 1:10).

Преимущественная крупность частиц шамота составляет 1-2 мм (зафиксированы частицы от 0,5 до 1,5 мм). Концентрация 1:6. Шамот был изготовлен из сосудов, содержавших в составе ФМ искусственно добавленную примесь раковины моллюсков.

В изломах фрагментов зафиксировано наличие отпечатков, связываемых с растительными остатками - единичные отпечатки плоских частей растений и их волокон (величина 0,2-0,6 мм), а также небольшие округлые поры с темными стенками (величина 0,1-0,2 мм). Кроме того, прослеживаются признаки присутствия органического раство$p a$ - наличие светло-коричневого налета в пустотах от шамота, между слоями глины и в некоторых крупных порах. Учитывая совокупность указанных органических компонентов ФМ, можно предварительно сделать вывод об использовании в качестве добавки выюжики из навоза жвачных животных.

Группа IV. Глина + шамот + органическая добавка (предположительно выюнимка из навоза).

Для изготовления сосудов была использована среднезапесоченная (условно среднепластичная) $O Г$ (рис. к приложению 1: 11, 1: 12). По своим характеристикам она близка среднезапесоченному ИПС второй группы. Ее отличает присутствие в составе естественной примеси кваризевого песка крупностью 0,1-0,2 мм в концуентрацчии 50-60 включений на 1 cм² (окатанной и полуокатанной формы; прозрачный и полупрозрачный, изредка светло-коричневый и белесый), кваричевого песка крупностью 0,3-0,5 мм в концеентрации до 10 включений на 1 cм² (окатанной формы, прозрачный и полупрозрачный) и песка пьлевидной фракичии (<0,1 мМ) в средней концентрации. Зафиксированы включения конкрециий окисей железа и оолитов бурого железняка (рис. 1: 15).

В состав ФМ входит примесь шамота, преимущественная величина частиц которого варьирует от 1 до 2 мм. При этом встречаются включения размером от 0,5 до 5 мм. Скорее всего, перед добавлением в ФМ шамот калибровался и использовался совместно с образовавшимися при дроблении мельчайшими частицами. Концентрация шамота в ФМ составляет в двух случаях 1:6 и в одном - 1:7/1:8. В одном из образцов зафиксирован шамот, для изготовления которого были использованы сосуды, вылепленные из неза- песоченного ИПС с примесью термически обработанной раковины (близки сосудам группы Іа) (рис. 2: 13, 2: 14). Еще в одном образце прослежены частицы шамота, изготовленные из сосудов, вылепленных из среднезапесоченного ИПС с добавлением измельченной раковины моллюсков и шамота (рис. 2: 15).

Органический раствор фиксируется по наличию полупрозрачного налета светлокоричневых оттенков. Он находится на стенках некоторых пор и пустот, в том числе от шамота и растительных волокон. Также в изломах встречаются единичные углефицированные частицы растительных остатков и их отпечатки. Они представлены фрагментами плоских и округлых в сечении стеблей растений и их отдельными волокнами (длина 0,2-5,5 мм, диаметр 0,1-1 мм, ширина 0,1-0,3 мм) (рис. 2: 9, 2: 11). Сочетание признаков органического раствора с наличием в составе формовочной массы сильно фрагментированных растительных остатков можно предварительно интерпретировать как использование выжимки из навоза жвачных животных.

Изучение гончарной технологии на подготовительной стадии производства позволяет сделать заключение о существовании на территории городища как минимум двух различных групп населения, гончары которых руководствовались разными представлениями о пригодном для изготовления сосудов исходном сырье и рецептах составления формовочных масс. С одной стороны, это население, которое изготавливало сосуды преимущуественно из незапесоченных и слабозапесоченных глин (условно пластичных) $c$ использованием примеси термически обработанной (жареной) раковиньл моллюсков (I-III группа), а с другой - население, гончары которого подготавливали ФМ на основе среднезапесоченных глин с добавлением минеральной примеси иамота и органических компоненmов (груnпа IV). При этом нужно отметить, что население, которое изготавливало сосуды I-III группы не было однородным, что проявилось в использовании нескольких рецептов ФМ, в том числе и смешанных многокомпонентных (глина + раковина моллюсков + шамот). Примечательно, что сосуд, отнесенный к III группе, хоть и не содержит в составе формовочной массы примесь раковины, но ее присутствие зафиксировано в шамоте, для изготовления которого были использованы сосуды, близкие сосудам из группы I a.

Фрагменты с сетчатыли отпечатками. Изготовлены из слабозапесоченной 
(условно пластичной) ОГ. Она содержит естественную примесь квариевого песка крупностью 0,1-0,2 мм в кониентрации до 20 включений на $1 \mathrm{~cm}^{2}$ (окатанной и полуокатанной формы; прозрачный и полупрозрачный, изредка белесый), квариевого песка крупностью 0,3-0,5 мм в единичной конщентращии и песка пьлевидной фракиии (<0,1 мм) в малой концентрации. Также встречаются включения конкреций окисей железа яркого краснокоричневого ивета, рыхльх по структуре. В состав формовочной массы входит минеральная примесь в виде шамота и органическая в виде раствора. Преимущественная крупность шамота составляет 1-2 мм (зафиксированы частицы от 0,5 до 6 мм), концентрация 1:6. Органический раствор фиксируется по наличию углефицированных фрагментов и отпечатков плоских частей стеблей растений (величина 0,2-2 мм; концентрация 3-7 включений на $1 \mathrm{~cm}^{2}$ ), а также по наличию светлокоричневого налета в пустотах от шамота, между слоями глины и в некоторых крупных порах. Органический раствор может быть определен как выжимка из навоза жвачных животных.

\section{ЛИТЕРАТУРА}

Бобринский, А.А. Гончарство Восточной Европы: источники и методы изучения. М.: Наука, 1978. $272 \mathrm{c.}$.

Бобринский А.А. Гончарная технология как объект историко-культурного изучения // Актуальные проблемы изучения древнего гончарства. Самара, 1999. С. 5-109.

Цетлин Ю.Б. Древняя керамика. Теория и методы историко-культурного подхода М.: ИА РАН, 2012. $380 \mathrm{c}$. $346 \mathrm{c}$.

Цетлин Ю.Б. Керамика. Понятия и термины историко-культурного подхода. М.: ИА РАН, 2017.

Салугина Н.П. Идентификация раковины в составе древней керамики: критерии различения естественного или искусственного характера // Традиции и инновации в изучении древней керамики. Материалы международной научной конференции 24-27 мая, Санкт-Петербург. СПб: ИИМК РАН, 2016. C. 68-70.

\section{Информация об авторе:}

Швецова Анастасия Александровна, младший научный сотрудник Нижегородского государственного историко-архитектурного музея-заповедника (г. Нижний Новгород, Россия); asendriy@mail. $\mathrm{ru}$ 

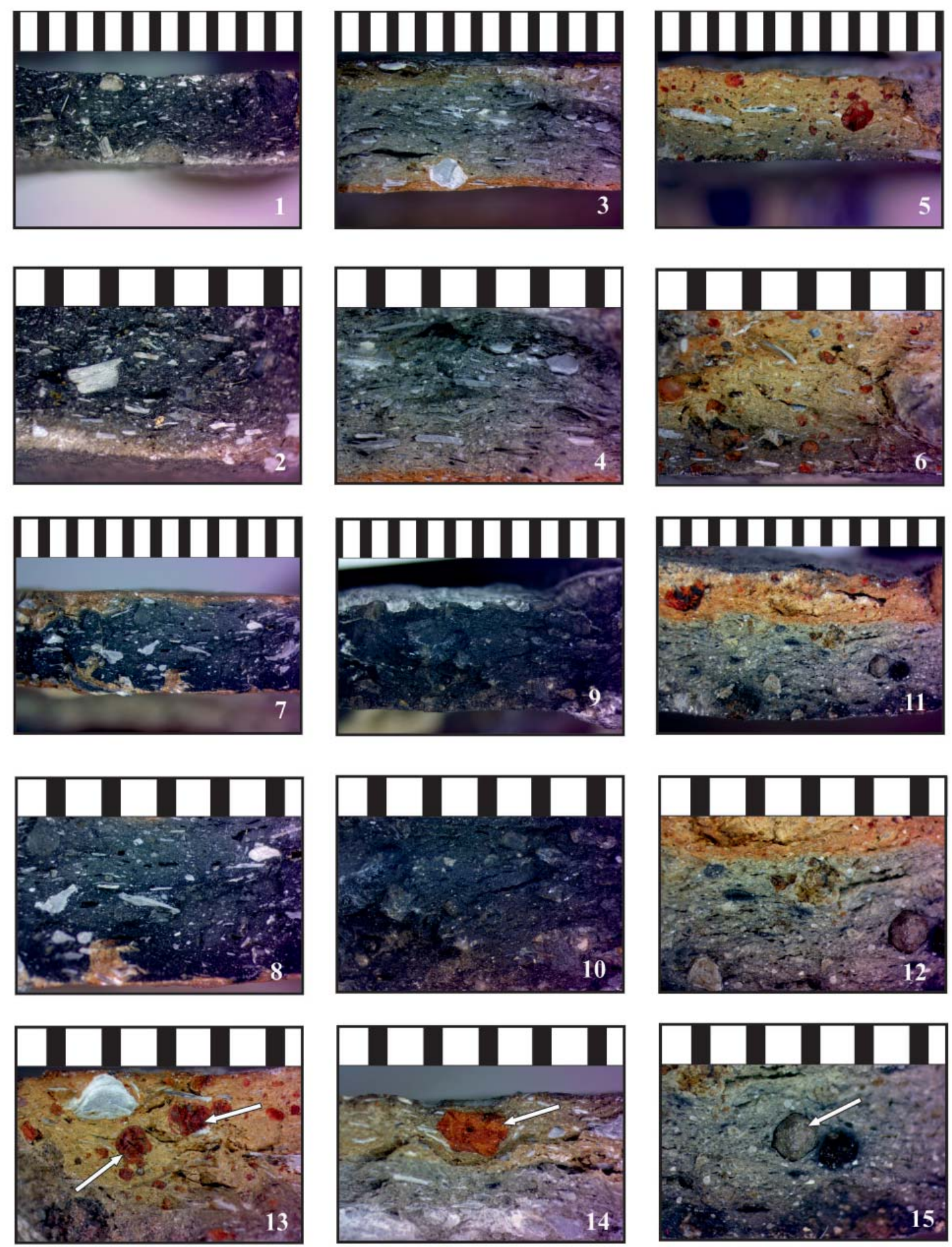

Рис. 1. Естественные примеси в составе исходного пластичного сырья (ИПС)

1-2 - ИПС группы сосудов Іа - незапесоченная ожелезненная глина (увеличение в 10-20 раз); 3-4 - ИПС группы сосудов Іб - среднезапесоченная ожелезненная глина; 5-6 - ИПС группы сосудов ІІа - незапесоченная ожелезненная глина; 7-8 - ИПС группы сосудов ІІб - слабозапесоченная ожелезненная глина;

9-10 - ИПС группы сосудов III - незапесоченная ожелезненная глина; 11-12 - ИПС группы сосудов

IV - среднезапесоченная ожелезненная глина; 13-14 - включения конкреций окисей железа; 15 - включения оолита бурого железняка

Fig 1. Natural impurities in the composition of the original plastic raw material (PRM)

1-2 - PRM of vessel group Ia - non-sandy iron clay (a 10-20 - fold increase); 3-4 - PRM of vessel group Ib - medium sandy iron clay; 5-6 - PRM of vessel group IIa - non-sandy iron clay; 7-8 - PRM of vessel group IIb - slightly sandy iron clay; 9-10 - PRM of vessel group III - non-sandy iron clay; 11-12 - PRM of vessel group IV - medium sandy iron clay; 13-14 - inclusions of iron oxide nodules; 15 - inclusions of brown iron ore oolite 

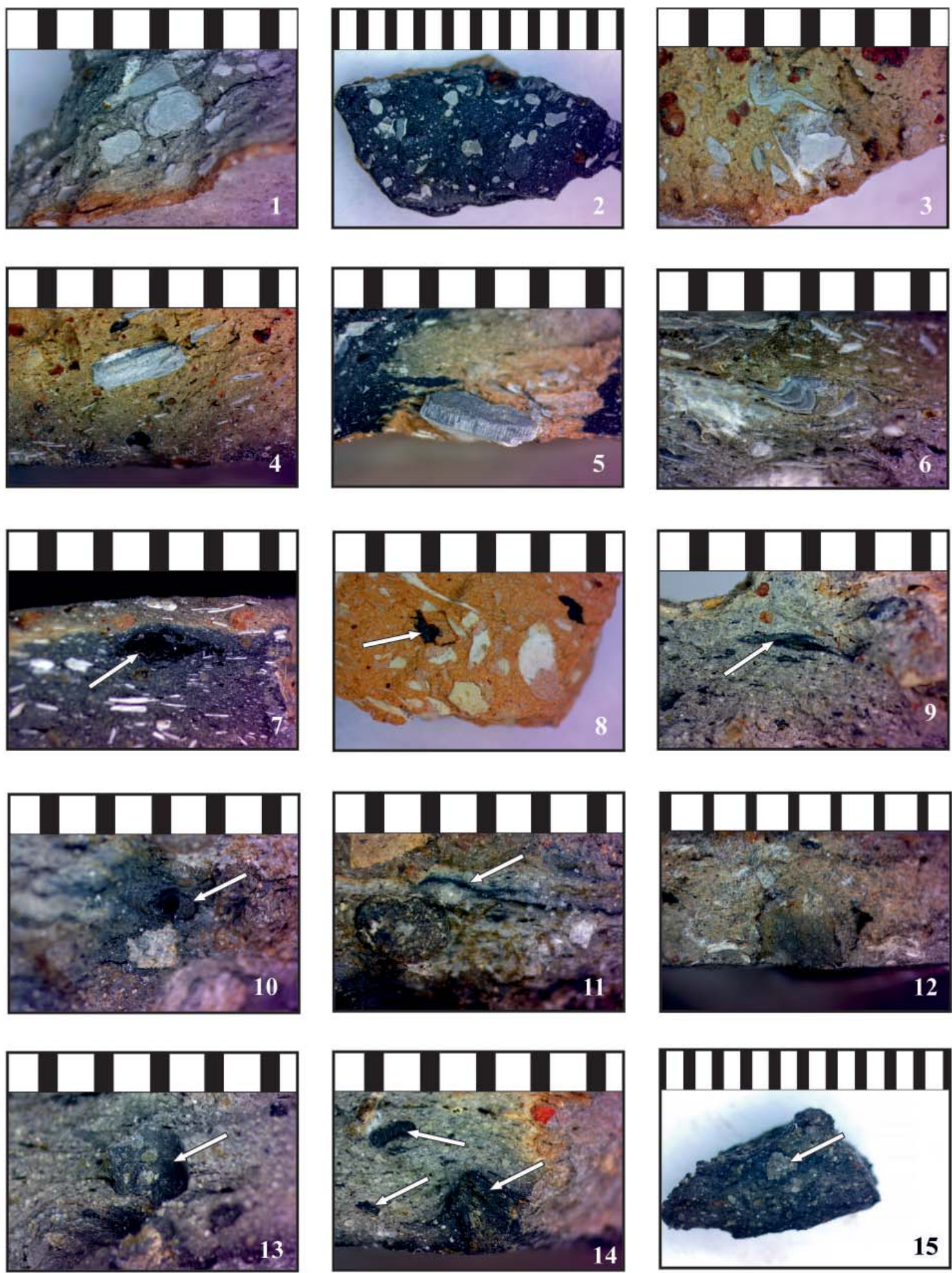

Рис. 2.. Искусственные примеси в составе формовочных масс (ФМ)

1-6 - примесь фрагментов раковины моллюсков; 7-8 - включения фрагментов тела моллюска; 9-11 - включения растительных остатков; 12-15 - примесь шамота (13, 14 шамот с примесью термически обработанной (жареной) раковины моллюсков; 15 - выпавший из образца шамот с включением шамота).

Масштаб в мм: одно деление белого цвета равно 1 мм

Fig. 2. Artificial impurities in molding compounds (MC)

1-6 - admixture of shellish fragments; 7-8 - inclusions of mollusk body fragments; 9-11 - inclusions of plant residues;

12-15 - admixture of chamotte (13,14 - chamotte with an admixture of thermally treated (fried) mollusk shells; 15 chamotte having dropped out of the sample with a chamotte inclusion)

Scale in mm: one white mark equals $1 \mathrm{~mm}$ 